\title{
Tropical wetlands for climate change adaptation and mitigation
}

Science and policy imperatives with special reference to Indonesia

\section{Editors}

Daniel Murdiyarso

J. Boone Kauffman

Matthew Warren

Emilia Pramova

Kristell Hergoualc' $h$ 



\title{
Tropical wetlands for climate change adaptation and mitigation
}

Science and policy imperatives with special reference to Indonesia

\author{
Editors \\ Daniel Murdiyarso \\ Center for International Forestry Research (CIFOR) \\ J. Boone Kauffman \\ Department of Fisheries and Wildlife, Oregon State University and CIFOR \\ Matthew Warren \\ USDA Forest Service \\ Emilia Pramova \\ Center for International Forestry Research (CIFOR) \\ Kristell Hergoualc' $h$ \\ Center for International Forestry Research (CIFOR)
}


Working Paper 91

(c) 2012 Center for International Forestry Research

All rights reserved

Murdiyarso, D., Kauffman, J.B., Warren, M., Pramova, E. and Hergoualc'h, K. 2012 Tropical wetlands for climate change adaptation and mitigation: Science and policy imperatives with special reference to Indonesia.

Working Paper 91. CIFOR, Bogor, Indonesia.

Cover photo by Matthew Warren/USDA Forest Service

Kuba Raya fishermen

CIFOR

Jl. CIFOR, Situ Gede

Bogor Barat 16115

Indonesia

$\mathrm{T}+62(251) 8622-622$

$\mathrm{F}+62$ (251) 8622-100

E cifor@cgiar.org

\section{cifor.org}

Any views expressed in this publication are those of the authors. They do not necessarily represent the views of CIFOR, the authors' institutions or the financial sponsors of this publication. 


\section{Table of contents}

Abbreviations $\quad$ v

Preface $\quad$ vii

Executive summary viii

1 Introduction 1

2 Greenhouse gas fluxes and flux changes from land-use dynamics in tropical wetlands 5

2.1 Background 5

$\begin{array}{ll}2.2 & \text { Current estimates of greenhouse gas emissions } \\ 2.3 & 6\end{array}$

$\begin{array}{lll}2.3 & \text { Issues and gaps } & 7\end{array}$

$\begin{array}{ll}2.4 \text { Recommendations } & 8\end{array}$

3 Ecosystem carbon stocks and land-use and land-cover change in tropical wetlands $\quad 10$

$\begin{array}{lll}3.1 \text { Background } & 10\end{array}$

$\begin{array}{ll}3.2 & \text { Land-use change }\end{array}$

3.3 Carbon stock changes associated with land-use changes 12

3.4 Knowledge gaps 12

3.5 Challenges to carbon stock and land-use and land-cover change assessment 13

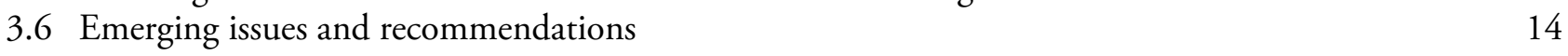

4 Ecosystem modelling of tropical wetlands $\quad 15$

$\begin{array}{ll}4.1 \text { Background } & 15\end{array}$

$\begin{array}{ll}4.2 & \text { State of the science }\end{array}$

$\begin{array}{ll}4.3 \text { Priorities and recommendations } & 17\end{array}$

5 The use of remote sensing to monitor land-use and land-cover change in tropical wetlands $\quad 18$

5.1 Background 18

$\begin{array}{ll}5.2 \text { What can be monitored? } & 18\end{array}$

5.3 How is remote sensing being used to monitor wetlands? $\quad 18$

5.4 What should be improved? 20

5.5 Key recommendations for Indonesia $\quad 22$

6 Revisiting the wetlands chapter in the 2006 IPCC Guidelines 23

$\begin{array}{lll}6.1 \text { Background } & 23\end{array}$

$\begin{array}{ll}6.2 & \text { Issues and gaps }\end{array}$

6.3 Accounting approaches $\quad 23$

$\begin{array}{ll}6.4 \text { Recommendations } & 25\end{array}$

7 Human dimensions and the roles of tropical wetlands in adaptation to climate change 28

$\begin{array}{lll}7.1 \text { Background } & 28\end{array}$

7.2 Socio-ecological systems and the knowledge needed for adaptation 29

7.3 Approaches to building and communicating knowledge 32

7.4 Recommendations 34

8 The way forward $\quad 37$

$\begin{array}{lll}8.1 & \text { The approach } & 37\end{array}$

8.2 Consolidation of knowledge and networks 38

$\begin{array}{ll}8.3 \text { Scaling up measurements and integrated assessments } & 40\end{array}$

$\begin{array}{ll}8.4 \text { Science-policy dialogue } & 41\end{array}$

8.5 Synergies between adaptation and mitigation $\quad 41$

9 References $\quad 43$

Appendices

1 Status and gaps in the use of remote sensing in wetlands monitoring 49

2 Workshop participants $\quad 52$ 


\section{List of figures, tables and boxes}

\section{Figures}

4.1 The Holocene Peat Model (HPM) that simulates the interaction of carbon and water and vegetation dynamics in peatland (a), and calculates the annual peatland carbon and water balance in one (vertical) dimension (b), where NPP is Net Primary Production

4.2 Structure of the carbon (a) and nitrogen (b) components of ECOSSE 17

5.1 Peatland land-cover distribution in Borneo 1990-2010 19

5.2 Land-use change of mangroves in the Mahakam delta in East Kalimantan, Indonesia, 2000-2010 20

5.3 Wall-to wall map produced by modeling GLAS points with a regression tree approach 20

5.4 Using LIDAR data for the assessment of peat oxidation by fire at different elevation above sea level 21

7.1 Vulnerability as a function of exposure, sensitivity and adaptive capacity 28

7.2 Climatic and non-climatic impacts on mangroves 30

7.3 Vulnerability assessment framework of coupled human-environment systems 33

\section{Tables}

1.1 Ecosystem functions, goods and services that can be quantified for tropical wetland forests 2

3.1 Examples of land uses occurring on tropical wetland soils in Indonesia 11

5.1 Key wetland variables that can benefit from remote sensing approaches, and related observation parameters

5.2 Key gaps and recommendations on improving the use of remote sensing for wetland monitoring and analysis

6.12006 IPCC Guidelines for two activities on two wetlands subcategories

6.2 Activities in wetlands and adequacy for emissions factors and quantification methods 26

7.1 Example indicators for scenario analysis 35

8.1 Summary of knowledge assessments and identified knowledge gaps to guide research priorities 39 


\section{Abbreviations}

AASTR

ALOS-AVNIR

ALOS-PALSAR

AusAID

AVHRR

BIRD

CI

CIFOR

CIMTROP

CIRAD

CRISP

CSIRO

DMC

DNPI

EC-SSFFMP

ESA-PWA

FFI

FIRMS

FORCLIME

FORDA

GIZ

GLAS

GOSAT

IAFCP

ICRAF

IFFM

In-SAR

IPCC

JAXA

JICA

JST

LAPAN

LIDAR

LIPI

LMU

LUCC

LULUCF

MIT
Advanced Along-Track Scanning Radiometer

Advanced Land Observing Satellite-Advanced Visible and Near Infrared Radiometer

Advanced Land Observing Satellite- Phased Array type L-band Synthetic Aperture Radar Australian Government Overseas Aid Program

Advanced Very High Resolution Radiometer

Bi-spectral IR Detection

Conservation International

Center for International Forestry Research

Center for International Cooperation in Sustainable Management of Tropical Peatland

Centre International de la Recherche Agronomique pour le Develompment

Centre for Remote Imaging, Sensing and Processing

Commonwealth Scientific and Industrial Research Organisation

Disaster Monitoring Constellation

Dewan Nasional Perubahan Iklim

European Commission-South Sumatra Forest Fire Management Project

Environmental Science Associates-Philip Williams \& Associates, Ltd.

Fauna and Flora International

Fire Information for Resource Management System

Forests and Climate Change Programme

Forestry Research and Development Agency

Gesellschaftfür Internationale Zusammenarbeit

Geoscience Laser Altimeter System

Greenhouse gases Observing SATellite

Indonesian-Australia Forest Carbon Partnership

International Centre for Research on Agroforestry

Integrated Forest Fire Management

Interferometric Synthetic Aperture Radar

Intergovernmental Panel on Climate Change

Japan Aerospace Exploration Agency

Japan International Cooperation Agency

Japan Science and Technology Agency

Lembaga Penerbangan dan Antariksa Nasional

Light Detection and Ranging

Lembaga Ilmu Pengetahuan Indonesia

Ludwig Maximilians Universitat Muenchen

Land-use/cover change

land-use and land-usechange and forestry

Massachusetts Institute of Technology 
MODIS Moderate Resolution Imaging Spectroradiometer

MoE Ministry of Environment

MoF Ministry of Forestry

MRRP-GIZ Merang REDD Pilot Project-GesellschaftfürInternationale Zusammenarbeit

NASA

NFI

National Aeronautics and Space Administration

NOAA

National Forest Inventory

RADAR

National Oceanic and Atmospheric Administration

REDD

Radio detection and ranging

RePPProT

Reducing Emissions from Deforestation and Forest Degradation

RS

Regional Physical Planning Project for Transmigration

RSAC

Remote Sensing

RSS

Remote Sensing Applications Center

SAR

Remote Sensing Solutions

SPOT

Synthetic Aperture Radar

SRTM

Systčme Pour l'Observation de la Terre

TerraSAR-X

Shuttle Radar Topography Mission

UMD

Terra Synthetic Aperture Radar X-Band

University of Maryland

UNEP

United Nations Environment Programme

USFS

United States Forest Service

USGS-DRAGON United States Geological Survey-Delta Research and Global Observation Network

WHRC

Woods Hole Research Center

WRI

World Resources Institute

WWF

World Wildlife Fund

ZSL

Zoological Society of London 


\section{Preface}

Tropical forested wetlands, especially peat swamp forests and mangroves, provide numerous environmental services and critical ecological functions, affecting both upland and oceanic ecosystems and the people who depend on them. These forests offer protection from storms and tsunamis, flood control, regulation of water quality, breeding and rearing habitats for many species of fish and shellfish, sources of wood and other forest products, and great biodiversity as habitats for many rare and endangered plant, animal and insect species. They are also a source of nutrients and energy for adjacent habitats including seagrass and coral reefs, and are also valued for aesthetics and ecotourism. Tropical wetlands have been used for centuries by indigenous people for wood, thatch, medicines, dyes, and fish and shellfish. Perhaps the least investigated, yet critically important ecosystem service of tropical wetlands, is providing a carbon sink. Because tropical wetlands have high rates of primary productivity as well as anaerobic soil conditions that limit decomposition, carbon stocks are among the highest of any forest type.

Indonesia is a nation with remarkable wetlands and associated resources. Approximately $47 \%$ of the world's tropical peatlands and $23 \%$ of its mangroves occur throughout the archipelago. However, Indonesia's wetland forests are under considerable pressure from land-use and land-cover change, evidenced by high deforestation rates and fire occurrence since 1980s. Deforestation of peat forests is largely related to the establishment of unsustainable oil palm and pulp wood plantations resulting in the release of tremendous carbon emissions stored in the peat. Losses of mangroves are largely due to conversion to aquaculture, agriculture and coastal development, and upstream disruptions to hydrology and sediment delivery.

The extent of tropical wetlands, the magnitude of loss, and the related socioeconomic ramifications of the destruction of Indonesian wetlands are of global significance. The carbon density and rates of land-cover change in these ecosystems are amongst the highest of any forest type on Earth. Therefore, addressing interrelated issues of climate change and land use could be valuable in generating new options on how mangroves and peatlands should be best managed.
To help define the state of our knowledge on tropical wetlands and the scientific information needed to manage these ecosystems in a rapidly changing world, a workshop was organised in Bali, Indonesia in April 2011. This was part of the Tropical Wetlands Initiative for Climate Adaptation and Mitigation (TWINCAM), jointly implemented by the Center for International Forestry Research (CIFOR) and the United States Forest Service (USFS). The purpose of the workshop was to bring together Indonesian and international scientists from diverse backgrounds and with diverse experiences in both freshwater and coastal tropical wetlands to describe the state of the science, significant research needs, and potential transdisciplinary approaches necessary to implement climate change adaptation and mitigation strategies.

Many of the world's leading tropical wetlands scientists attended the workshop, recognising the need for research collaboration. We would like to extend our thanks for their contributions in both presentations and break-out group discussions. We are also grateful to key speakers who set the scene, including Jyrki Jauhiainen on greenhouse gas flux, Boone Kauffman on carbon stock dynamics, Pep Canadell on ecosystem modelling, Florian Siegert on use of remote sensing, Louis Verchot on the Intergovernmental Panel on Climate Change (IPCC) processes, and Terry Hills on adaptation to climate change. All presentations may be viewed at: http:// www.forestsclimatechange.org/events/ workshop-ontropical-wetlandhtml.html.

We would also like to acknowledge the financial support provided for this workshop by the United States Department of State and the United States Agency for International Development. Practical assistance was provided by the Indonesian Forest Research and Development Agency (FORDA) and the Sekala Foundation, who we also thank.

Although the report's focus is on tropical wetlands of Indonesia, the results and recommendations presented here are relevant and useful for those interested in wetlands throughout the tropics.

Editors 


\section{Executive summary}

\section{Why are tropical wetlands so important?}

Indonesia has more tropical peat swamp and mangrove forests than any other nation on Earth. The country has about 21 million hectares of tropical peat swamp forests and about 3 million ha of mangroves. Globally this accounts for half of tropical peat swamp forests and almost a quarter of the world's mangroves.

These ecosystems are highly productive and harbour a unique range of aquatic and terrestrial biodiversity. They also play an important role in controlling the delivery of water from terrestrial to aquatic ecosystems and provide a buffering function against the transmission of pollutants across this interface. Mangroves are important sources of energy and nutrients for coral reefs, buffer coastal zones from tropical storms, and are extremely valuable as fish and wildlife nurseries. Because of the accumulation of carbon over several millennia, Indonesia's tropical peatlands and mangroves are among the largest terrestrial carbon pools on Earth (Donato et al. 2011, Murdiyarso et al. 2010).

The rates of land-cover change occurring in tropical wetlands are among the highest of any forest type. An estimated $45 \%$ of Indonesia's peat forests have been deforested or drained, thus creating a shift in their function from globally significant carbon sinks to globally significant sources of $\mathrm{CO}_{2}$ emissions. In general, $63 \%$ of emissions from peat swamp forest conversion arises from the decomposition of peat (Hergoualc'h and Verchot 2011).

Tropical wetlands are of great interest because of the numerous ecosystem services at risk and the large amounts of greenhouse gas emissions that arise from land conversion. Additional interests are related to their roles in mitigating climate change and the important need to develop adaptation strategies to climate change in these ecosystems. Economic opportunities are emerging through the global mechanism known as REDD+ (reducing emissions from deforestation and forest degradation, and enhancing forest carbon stocks in developing countries) (Murdiyarso et al. 2010). Co-benefits derived from the conservation or restoration of standing forests growing on wetlands, such as biodiversity, aesthetics and ecotourism, non-timber forest products, and watershed protection are also potential financial incentives.

Biogeochemical cycles of tropical wetlands are complex, unique and globally significant. Understanding emissions, stocks and sequestration would improve the uncertainties in monitoring, reporting and verification (MRV) of the greenhouse gas emissions associated with land-use and land-cover change (LULCC).

\section{Science is needed}

Clearly a scientific basis is needed to address the challenges of managing these ecosystems in the face of rapidly increasing land conversion and climate change. As such, the Center for International Forestry Research (CIFOR) and the United States Forest Service (USFS) convened an international workshop and symposium in Bali, Indonesia in 2011. The purpose of the workshop was to bring together Indonesian and international scientists from a broad diversity of backgrounds and experiences in both freshwater and coastal tropical wetlands. They gathered to describe the state of the science, significant research needs, and potential comprehensive multidisciplinary approaches to implementing climate change adaptation and mitigation strategies.

To address the purpose of the workshop, the programme included in-depth, break-out discussions of smaller groups on themes such as greenhouse gas flux processes, carbon stock changes due to LULCC, ecosystem modelling, use of remote sensing, links with the Intergovernmental Panel on Climate Change (IPCC) processes, and adaptation of wetlands to climate change and human dimensions.

As evidenced by the participation and presentations synthesised in this paper (http:// 
www.forestsclimatechange.org/workshop-ontropical-wetland.html), the world's leading tropical wetlands scientists recognise the need for research collaboration and are committed to it. A strong, collaborative research effort is needed across the Indonesian archipelago, focusing on tropical wetlands, to address information gaps relating to land use and climate change. Fortunately, partnerships are forming between Indonesian and international scientists to quantify carbon stocks, greenhouse gas sequestration and emissions. It is also important to have a well-coordinated research agenda that is highly relevant to the policy community and decision makers. Such a scientific research agenda could inform the public policy making processes for MRV and mitigation and adaptation strategies that are scientifically sound and socially acceptable. While the discussions focused on Indonesian wetlands, the implications of research will be of relevance to tropical wetlands through out the world, thus underscoring the global significance of this research.

\section{Synergising mitigation and adaptation}

The IPCC has developed methodologies for greenhouse gas inventories that have been widely used by parties to the United Nations Framework Convention on Climate Change (UNFCCC) for reporting purposes. The widely circulated report is often used as a reference for mitigation strategies and programmes. For developing countries like Indonesia, adoption and implementation of accepted methodologies and analyses is crucial in the development of mitigation strategies.

The IPCC Guidelines (IPCC 2006) have a land-use category for wetlands that is essentially limited to peatlands, with subcategories suitable to temperate peatland management. Unfortunately, these categories are not suitable for tropical peatlands, especially for the unique features of saline peatlands found in mangroves. Introducing additional activities to the IPCC Guidelines that are more relevant to tropical peatlands (including restoration - rewetting and restoration) brings opportunities as well as challenges. In addition, IPCC-listed activities that involve the use of fertiliser sand fire would be improved by the provision of new activity data and new emission factors from tropical wetlands. Knowledge generated from collaborative research on tropical wetlands in Indonesia can provide information of global relevance for the IPCC wetlands addendum.

Given the innumerable ecosystem services of tropical wetlands that are at risk, it is quite logical to include them in the global, national and local climate change adaptation agendas. Coastal wetlands such as mangrove ecosystems have proven their value in reducing the vulnerability of low-lying coastal zones to damage from storm surges, tropical cyclones, and to some extent tsunamis. Likewise, peat swamp forests function as 'landscape sponges', reducing flooding in wet seasons and gradually releasing the water during dry seasons.

Climate change impacts that most affect tropical wetlands and the people who depend on them include sea-level rise, increasing soil salinity, changes in temperature and rainfall patterns, and increasing frequency and severity of cyclones and El Niño events. Adaptation strategies specific to these wetlands are needed to protect ecosystem services for future generations. Mitigation procedures that preserve ecosystem resistance and resilience to climate change (e.g. REDD+) are also recommended as costeffective and ecologically sound adaptation strategies.

Adaptation to the impacts of climate change needs to be mainstreamed into the economic development planning and implementation process. Synergising adaptation and mitigation strategies would enhance the benefits for communities most vulnerable to climate change.

\section{The way forward}

Based on the presentations and discussions at the Workshop on Tropical Wetland Ecosystems of Indonesia, the following recommendations were made:

1. Multidisciplinary research studies are necessary to build a strong science-based approach that serves Indonesia's need to protect its unique wetland ecosystems. National and international scientists working on wetlands issues should facilitate collaborations to address key policy issues surrounding tropical wetlands, climate change adaptation and mitigation.

2. The scientific community should work closely to optimise resources and avoid duplication. Vast landscapes and crucial issues remain understudied 
in Indonesia. Improved communication and collaboration among agencies would minimise unnecessary overlaps. Regular meetings that facilitate exchange of knowledge should be promoted as they will assist in advancing the scientific wealth of Indonesia.

3. Carbon-rich tropical wetland ecosystems including mangroves and peatlands should be considered as high priorities in climate change adaptation and mitigation strategies throughout the world. Given the abundance of tropical wetlands, Indonesia has much to offer in the global climate agenda, such as the REDD+ mechanism.

4. The state of the science related to carbon and nitrogen cycling, the dynamics of LULCC and associated human dimensions are key components of the research agenda. Comprehensive field measurements should be encouraged to accurately quantify greenhouse gas fluxes and carbon stock changes resulting from LULCC in tropical wetlands.

5. Greenhouse gas flux is a complex interplay of biogeochemical processes and land-use dynamics, which are largely driven by land-use decisions made by local peoples, industries and government policies. Modelling tools may be devised to simulate land-use trajectories and their implications.

6. Remotely sensed determinations of LULCC supported by ground-truth data should be extensively used to reduce current uncertainties in quantifying the extent and carbon stock changes in tropical wetlands.

7. The existing IPCC Guidelines require substantial inputs to address the gap of the understated roles of tropical wetlands. The next IPCC processes will require close collaboration between governments and scientific community. 


\section{Introduction}

Matthew Warren, Daniel Murdiyarso and Boone Kauffman

Tropical wetlands are among the most productive ecosystems on Earth, containing unique aquatic and terrestrial communities high in biodiversity (Posa et al. 2011). Wetland forests occurring on organic soils -mangroves and freshwater peat swamp forestsare ubiquitous along coastlines and on coastal plains throughout the tropics. Inland peat swamp forests also occur within river basins at higher watershed positions (Anshari et al. 2010). Page et al. (2011) estimated that there were $441,025 \mathrm{~km}^{2}$ of tropical peatlands globally, distributed throughout 61 countries in Africa, Asia, Central America and the Caribbean, South America, Australia and the Pacific. The majority of tropical peat forests (about 56\%) occur in southeast Asia (Page et al. 2011). Mangrove forests occur exclusively in coastal and estuarine environments, and extend beyond $23.5^{\circ}$ latitude into subtropical regions. Globally, about 140000 $152000 \mathrm{~km}^{2}$ of mangrove forests are distributed throughout 118 countries (Giri et al. 2011). Southeast Asia and the Indo-Pacific are considered centres of mangrove distribution and diversity. Indonesia alone contains about $23 \%$ of the world's mangrove forests (Giri et al. 2010). Historically, tropical wetlands have received little attention in scientific literature and are among the lesser studied tropical ecosystems. However, large-scale greenhouse gas emissions associated with deforestation and forest degradation from land conversion and recurring catastrophic fires have sparked international concern over the fate of tropical wetlands. Because of their exceptional carbon storage and potential to become long-term sources of greenhouse gas emissions, the influence of tropical wetlands on the global carboncycle is highly disproportionate to their spatial extent.

Many threatened flagship species for conservation (including orangutans, rhinoceroses, Sumatran tigers, and flora such as Nepenthes pitcher plants and orchids) find refuge in Indonesia's peat forests and mangroves. Peatlands and mangroves also provide numerous ecosystem services to populations that rely on them for life and livelihood (Table 1.1). Coastal wetlands, especially mangroves, supply energy and nutrients to coral reefs and maintain fisheries by providing nursing and breeding habitat. Tropical wetlands protect inland areas from erosion, and dissipate energy from storm surges and to some extent, tsunamis. Mangroves buffer marine ecosystems from terrestrial sedimentation and pollutants. Peatlands and mangroves also store an immense amount of carbon from the steady accumulation of organic matter over several millennia (Donato et al. 2011, Page et al. 2011). Recent studies demonstrate that carbon pools in peat and mangrove forests are 3-5 times higher than those of upland tropical, temperate and boreal forests, emphasising their significance in the global carbon cycle (Murdiyarso et al. 2009, Donato et al. 2011). Ironically, deforestation rates of tropical wetlands are higher than any other tropical forest type, and drainage, clearing and burning continue at an alarming pace (Langner et al. 2007, Miettinen and Liew 2010a, Miettinen and Liew 2010b, Giri et al. 2011).

The ecosystem services and carbon storage of tropical wetlands are extremely vulnerable to the negative effects of climate change. Rising sea levels and increased frequency and severity of tropical cyclones are predicted for the next century, which will largely impact coastal wetlands and low-lying islands. Furthermore, altered precipitation patterns and increasing frequency of extreme climate events (such as drought associated with the El Nino Southern Oscillation) may increase the susceptibility of tropical wetland forests to fire (Li et al. 2007).Land conversion results in immediate, massive carbon fluxes to the atmosphere from deforestation and 
Table 1.1. Ecosystem functions, goods and services that can be quantified for tropical wetland forests

\begin{tabular}{|c|c|c|}
\hline Function & Goods and services & Quantifier \\
\hline Water regulation & Water supply to local communities & $\begin{array}{l}\text { Water yield: } \mathrm{m}^{3} \text { fresh water/ } \\
\text { household/year; seasonal discharge/ } \\
\text { baseflow }\left(\mathrm{m}^{3} / \mathrm{s}\right)\end{array}$ \\
\hline Climate regulation & Atmospheric $\mathrm{CO}_{2}$ sequestration & Mg carbon captured/ha/year \\
\hline $\begin{array}{l}\text { Breeding/nursing habitat for reef } \\
\text { and offshore fish }\end{array}$ & Fishery production/protein source & Annual catch (Mg/year) \\
\hline $\begin{array}{l}\text { Wave energy attenuation, } \\
\text { substrate stabilisation }\end{array}$ & $\begin{array}{l}\text { Coastal defence/protection of } \\
\text { settlements and infrastructure }\end{array}$ & $\begin{array}{l}\text { Number of households protected, } \\
\text { dyke maintenance costs avoided etc. }\end{array}$ \\
\hline Biodiversity conservation & $\begin{array}{l}\text { Habitat for endangered, threatened or } \\
\text { vulnerable species }\end{array}$ & Number of species protected \\
\hline Timber production & High value timber & $\mathrm{m}^{3}$ timber/ha/year \\
\hline Non-timber forest products & $\begin{array}{l}\text { Fruits, seeds, palms, ferns, honey, fungi, } \\
\text { medicinal plants, fish, crabs, etc. }\end{array}$ & $\begin{array}{l}\text { Economic value: monetary unit/year; } \\
\text { kg product consumed/year }\end{array}$ \\
\hline Cultural/heritage & Use of traditional religious sites & $\begin{array}{l}\text { Frequency and number of people } \\
\text { using site }\end{array}$ \\
\hline Ecotourism & Boat rides, wildlife viewing, camping, etc. & $\begin{array}{l}\text { Number of tourists/year; income } \\
\text { generated from tourism }\end{array}$ \\
\hline
\end{tabular}

Note: 'Quantifier' refers to units which can be used to measure goods and/or services.

burning (about $255 \mathrm{MgC} / \mathrm{ha}$ ) followed by longer term oxidative losses depending on hydrological conditions (Hooijer et al. 2010, Murdiyarso et al. 2010, Hergoualc'h and Verchot 2011). Murdiyarso et al. (2010) estimated that $25 \%$ of all carbon emissions from converting peat forest to oil palm plantation (a wide-spread land-use transition in Indonesia) occur from initial burning to clear the land. During the unusually severe fire season of 1997, drought conditions prompted opportunistic and uncontrolled burning, eventually affecting over 2 million ha of wetland ecosystems throughout Indonesia (Taconni 2003). Burning during the 1997 fire season resulted in losses commensurate with the $1.5 \mathrm{PgC}$ average annual flux from global land-use change in 1990-2005 (Page et al. 2002, Le Quéré et al. 2009). In addition, the smoke haze and transboundary pollution that defined the 1997 fires is now recurrent, with severe economic and public health impacts (Langmann and Heil 2004).

Wetland degradation negatively affects numerous ecosystem services, many of which are essential for the reduction of societal vulnerability to current climate hazards and future climate change. In addition, greenhouse gas emissions from large-scale wetland drainage and degradation can contribute to additional climate forcing. The interconnectivity among ecosystem services, climate adaptation and mitigation, vulnerability of large carbon pools to loss, and biodiversity conservation presents both opportunities and challenges for tropical wetland management. Clearly, there is a strong interest in sustainable wetland management and economic development. Implementation of science-based policy is needed to balance conservation, climate and economic development agendas. To address current research needs and opportunities, an international scientific workshop was held in Bali, Indonesia attended by tropical wetland scientists from throughout Indonesia and their international counterparts. The objectives of the workshop were to assess the current state of the science, significant research needs, and strategic multidisciplinary approaches for the implementation of climate change adaptation and mitigation strategies specific to tropical wetland forests. The subsequent chapters of this paper summarise the outcomes of working group discussions on six broad themes relevant to tropical wetlands research:

1. Greenhouse gas flux processes in tropical wetlands

2. Land-use and land-cover change and carbon stock changes in tropical wetlands 
3. Ecosystem modelling - predicting future wetland scenarios with climate change

4. Use of remote sensing - wetlands detection and monitoring

5. The IPCC Guidelines and processes in relation to tropical wetlands

6. Adaptation of wetlands to climate change and human dimensions.

Issues related to greenhouse gas fluxes and changes associated with land use are described in detail by Cobb et al. (Chapter 2). Carbon losses from drained and burned forests on organic soils are much greater than those associated with deforestation on upland mineral soil. In addition to the instantaneous combustion of aboveground biomass, carbon-dense surface layers (30 cm depth; Ballhorn et al. 2009) also burn, releasing large amounts of additional greenhouse gases into the atmosphere. Organic soil drainage results in physical collapse and large-scale heterotrophic oxidation of aerated organic matter. Carbon dioxide emissions resulting from peat drainage are persistent as long as the water table is artificially lowered to sustain yields of crop or plantation plants. Based on current understanding, several management options are available to help curtail the large greenhouse gas emissions associated with wetland alteration.

In Chapter 3, Warren et al. discuss current estimates of carbon stocks and how they are affected by landuse and land-cover change (LULCC). Tropical wetlands are among the highest reported ecosystem carbon pools on Earth, with 49-98\% of ecosystem carbon stored in their organic soils (Donato et al. 2011). However, the variability of carbon storage remains poorly described across wetland vegetation types and geographic locations. Several wetland forest types that developed under distinct geological, environmental and biological conditions are recognised. Yet, comprehensive ecosystem carbon stock estimates have only been reported for a few areas and land uses (Hergoualc'h and Verchot 2011). Several challenges and issues have precluded the analysis of carbon stock changes with LULCC, such as funding, access to information, technical capacity and infrastructure of local institutions, and accepted standard methodology. Overcoming these challenges and conducting future ecosystem carbon assessments using comparable methods are critical to quantifying how changes in land use impact local carbon storage and greenhouse gas emissions.
Predicting changes of ecosystem carbon storage or loss in response to drainage, disturbance, regrowth or rehabilitation would be helpful to assess the effects of current land-use activities on greenhouse gas emissions. Also, forecasting tools to determine future emissions based on different land-use scenarios would aid decision making processes. Techniques used to make these predictions need to include robust ecosystem models for tropical wetlands. Such models do not yet exist. Ecosystem modelling would be useful to achieve a better understanding of the internal carbon balance of tropical wetland forests, test for ecosystem responses to climate variability, extremes and change, and explore ecosystem thresholds under different management and climate scenarios. In Chapter 4, Hergoualc'h et al. discuss the current status of ecosystem model development for tropical wetlands. Some current models for temperate wetlands are being further developed and parameterised for tropical peat swamp forests; however, much work remains to be done. Data for accurate parameterisation and validation are lacking, and available data are constrained to a few wetland forest types and geographic locations. Continued model development with refined data input will be an exciting avenue of future research.

Measuring and monitoring LULCC in tropical wetlands relies on the application and development of remote sensing technologies. Herold et al. (Chapter 5) identify key areas where tropical wetland research can benefit from remote sensing. Furthermore, examples are provided which describe how advanced remote sensing techniques are being applied to measure changes in land use, aboveground biomass, and peat oxidation from fire. The use of remote sensing methods to scale up disturbance effects (e.g. fire) has played a large role in current estimates of carbon emissions from wetland landuse change. Integrating ground-based measurements with remote sensing tools will certainly continue to advance the measuring and monitoring of tropical wetland ecosystems.

The exceptional carbon storage and emissions from land-use change distinguish tropical wetland forests from other vegetation types. However, the IPCC Guidelines do not currently include considerations for measuring, monitoring and reporting greenhouse gas inventories for tropical wetlands. Murdiyarso et al. (Chapter 6) discuss the current status of the wetlands chapter in the 2006 IPCC Guidelines, 
and suggest specific provisions for tropical wetlands. Special considerations for tropical wetlands are necessary and highly relevant to the international climate change dialogue. Recent research has demonstrated the importance of marine 'blue' carbon and carbon stored in tropical organic soils for the global carbon cycle. Revising international policy guidelines to consider these important carbon pools is thus necessary to improve the management of greenhouse gas emissions in the future.

Rapid rates of wetland drainage, forest conversion, burning, degradation and loss can be connected to a diverse range of socioeconomic drivers. Tropical wetlands do not exist in isolation and have been inhabited and sustainably used for thousands of years in many areas. However, large-scale drainage, burning and conversion are recent phenomena as national development policies, perverse incentives and international market forces facilitate industrial expansion and growth in formally remote areas. In Chapter 7, Pramova et al. describe the human dimensions of tropical wetlands, their role in adaptation to climate variability and change, and the consequences of rapid conversion for social adaptive capacity. Wetland communities are especially vulnerable to the adverse effects of climate change, since the ecosystem services that they depend on are highly sensitive to both climatic and anthropogenic pressures. The vulnerability of wetland socioecological systems and related strategies for climate adaptation and mitigation need to be explored in a holistic manner, to benefit local communities and foster sustainable wetland management.
The final chapter of this paper discusses overall conclusions and recommendations generated from the synthesis of expert group reports and the final plenary session of the Bali wetlands workshop. Several parallel recommendations were independently identified by expert groups working on different research topics. It is clear that tropical wetland management will play a critical role in future climate adaptation and mitigation strategies. Management of tropical wetlands to ensure critical ecosystem services and to sustain significant carbon pools and sinks could simultaneously mitigate greenhouse gas emissions while reducing the vulnerability of local communities to the adverse effects of climate change. Wetland-based adaptation and mitigation need to be addressed in a synergistic manner in both science and policy.

To facilitate informed policy decisions, additional research and scientific consensus is needed to clarify current wetland definitions and classifications, devise standard methodologies for measuring and monitoring ecosystem variables, and to collect data for reliable scaling and integrated assessments. In addition, knowledge networks need to be consolidated to increase communication, target research priorities, and avoid redundancies. Finally, science-policy dialogue needs to be facilitated to ensure that current scientific understanding is considered in decision making affecting tropical wetlands and that decision making needs are addressed by science. 


\title{
2. Greenhouse gas fluxes and flux changes from land-use dynamics in tropical wetlands
}

\author{
Alex Cobb, Fahmuddin Agus, Matthew Warren, Grahame Applegate, Zoe Ryan, Victor Engel, Etik Puji Handayani, \\ Al Hooijer, Edi Husen, Jyrki Jauhiainen, Mujizat Kawaroe, Cecep Kusmana, Rumi Naito and Mitsuru Osaki
}

\subsection{Background}

The tropical peatlands of Borneo, Sumatra and peninsular Malaysia have developed on low-lying coastal plains and interior basins over the last $1000-13000$ years largely because waterlogged conditions slow decomposition (Dommain et al. 2011). Disturbance and land-use changes of intact peat swamp forests result in large net carbon losses, especially as atmospheric carbon dioxide flux from the peat soil (Hergoualc'h and Verchot 2011). A pulse of $\mathrm{CO}_{2}$ emissions from biomass and peat burning occurs with deforestation, and land-use changes expose upper peat layers to air and increased surface temperatures, which accelerate oxidation of organic matter.

Long-term $\mathrm{CO}_{2}$ emissions from peat decomposition are exacerbated by drainage (Hooijer et al. 2006, Germer and Sauerborn 2007). Such $\mathrm{CO}_{2}$ emissions from peat continue for as long as the water table is artificially lowered or until active carbon resources are exhausted. Selectively logged tropical peat forests are commonly drained, as canals are dug to transport cut timber. In addition, most common agricultural uses on peatlands require drainage for survival of planted species. The drainage depth required for cultivating oil palm on peat, for instance, is $60-80 \mathrm{~cm}$ (RSPO 2007) but drainage is often deeper in practice (Hooijer et al. 2010).

Peat organic matter oxidation, in combination with compaction and consolidation, leads to subsidence of converted peatlands, and the peat surface becomes lower and lower (Hooijer et al. 2006). One study (Couwenberg et al. 2010) suggested that peat subsidence rates increase proportionally with drainage for depths less than $50 \mathrm{~cm}$, implying an associated linear increase in carbon emissions to the atmosphere. Draining and burning peat swamp forest for conversion to agriculture will result in net carbon losses over time scales of hundreds of years, even taking into account avoided petrochemical emissions, when the conversion is for biofuels (Fargione et al. 2008). Moreover, the rate of peat carbon loss following disturbance and land-use change is much higher than the rate of peat carbon sequestration in natural peat swamp ecosystems (Couwenberg et al. 2010, Dommain et al. 2011). This implies that peat carbon losses resulting from deforestation and landuse change of a small area are not offset by natural carbon sequestration in a much larger area.

Fluxes of non- $\mathrm{CO}_{2}$ greenhouse gases (nitrous oxide and methane), appear to be very low compared to that of carbon dioxide in tropical peat (Inubushi et al. 2003, Jauhiainen et al. 2005, 2008, Melling et al. 2005, 2007, Watanabe et al. 2009, Couwenberg et al. 2010). Nevertheless, available data indicate that methane emissions are variable, and higher than those of upland mineral soils. In addition, nitrous oxide emissions can increase considerably when high levels of nitrogen fertilisers are applied (Takakai et al. 2006).

Unmanaged degraded peatlands are highly susceptible to fire, especially if easily ignited fuel loads are present, such as dried grasses and shrubs. Fire spreads easily through vegetation and drained peat, releasing huge amounts of carbon in a very short time (Page et al. 2002, van der Werf et al. 2008, Miettinen et al. 2012). Fire also reduces the level of the peat surface (Ballhorn et al. 2009). Fire risk is exacerbated by El Nińo drought events (Siegert et al. 2001, van der Werf et al. 2008), and clearly policy and management practices play essential roles in fire management (Field et al. 2009, Langner and Siegert 2009). 


\subsection{Current estimates of greenhouse gas emissions}

Estimates of greenhouse gas emissions from tropical peatlands include fire-related emissions calculated from changes in peat carbon stocks, annual fluxes scaled from instantaneous ground-based chamber measurements, flux tower estimates using eddy covariance methods, and estimates derived from relationships among water table depth, subsidence and $\mathrm{CO}_{2}$ emissions on drained peatlands. Fire-related emissions have been estimated by calculating peat loss from the burn scar area and average depth, and assumed carbon density $\left(\mathrm{gC} / \mathrm{cm}^{3}\right.$ soil) to determine total carbon loss.

Uncertainty in these variables results in a wide range of estimates. For example, Page et al. (2002) estimated that $0.81-2.57 \mathrm{GtC}$ was released to the atmosphere from Indonesian peat fires in 1997, while Langmann and Heil (2004) estimated carbon emissions of $0.38-1.6 \mathrm{GtC}$ over the same season. Ballhorn et al. (2009), however, estimated 0.11$0.39 \mathrm{GtC}$ was lost to the atmosphere from burning Indonesian peat during the less severe 2006 fire season. The variation in carbon emission estimates from fire can be attributed to differences in the area of burned peatland considered, biomass components included in the analysis, and assumptions related to burn scar depth, peat bulk density and carbon content among studies and fire seasons. The multiple approaches taken by various researchers to determine carbon emissions from fire complicate comparability among data sets and preclude reliable estimates of their interannual variability.

A number of studies have quantified greenhouse gas $\left(\mathrm{CO}_{2}, \mathrm{CH}_{4}\right.$ and $\left.\mathrm{N}_{2} \mathrm{O}\right)$ fluxes from tropical peat soils using static chamber methods. Recent literature reviews are provided by Couwenberg et al. (2010), Murdiyarso et al. (2010) and Hergoualc'h and Verchot (2011). Previous estimates of total soil respiration for forested peatlands were 8.134.6 $\mathrm{MgCO}_{2} \mathrm{ha}^{-1} \mathrm{yr}^{-1}$ (about 2.2-9.4 $\mathrm{MgC} \mathrm{ha}^{-1}$ $\left.\mathrm{yr}^{-1}\right)$, and are not significantly different among multiple land uses due to the high variability of estimates within land-use types (Hergoualc'h and Verchot 2011). A recent study by Jauhiainen $e t$ al. (2012) reported that temperature corrected total soil $\mathrm{CO}_{2}$ emissions were $80 \mathrm{MgCO}_{2} \mathrm{ha}^{-1} \mathrm{yr}^{-1}$ from an Acacia plantation. The plantation studied was drained to an average depth of $0.8 \mathrm{~m}$ (Jauhiainen et al. 2012). In the same study, about $63.2 \mathrm{MgCO}_{2}$ $\mathrm{ha}^{-1} \mathrm{yr}^{-1}(79 \%)$ of total emissions were estimated from measured heterotrophic oxidation of the peat. Few other studies have directly partitioned total soil respiration into heterotrophic and autotrophic components in tropical peatlands, particularly for peatlands with natural forest cover. Based on a literature review, Hergoualc'h and Verchot (2011) estimated that about $53 \pm 14 \%$ of total soil $\mathrm{CO}_{2}$ emissions are from heterotrophic peat oxidation in intact forests, which increases to $71 \pm 26 \%$ in oil palm plantations. The net contribution of peat decomposition to greenhouse gas emissions is equivalent to heterotrophic soil respiration minus new peat formation from carbon inputs, which are often considered negligible. Therefore, partitioning autotrophic and heterotrophic components of total soil $\mathrm{CO}_{2}$ emissions is critical to estimating greenhouse gas emissions from peatlands, as each source of $\mathrm{CO}_{2}$ will likely respond differently to changing physical and biological conditions associated with land-use change.

Studies of $\mathrm{CH}_{4}$ emissions from tropical peat soil indicate considerable variation, and have led to a general belief that soil $\mathrm{CO}_{2}$ fluxes are the dominant greenhouse gas emissions on peatlands, with the exception of rice paddies, where $\mathrm{CH}_{4}$ emissions are exceptionally high. Rates of $\mathrm{CH}_{4}$ emissions from peat soils are reported to range from $-2.8 \mathrm{kgC} \mathrm{ha}^{-1} \mathrm{yr}^{-1}$ in drained forest to $371.4 \mathrm{kgC} \mathrm{ha}^{-1} \mathrm{yr}^{-1}$ in lowland rice paddieson peat, and are negatively correlated with water table depth (Couwenberg 2010, Hergoualc'h and Verchot 2011). Values for intact peat swamp forest are reported to be $0.2-72.3 \mathrm{kgC} \mathrm{ha}^{-1} \mathrm{yr}^{-1}$ (Hergoualc'h and Verchot 2011). Couwenberg et al. (2010) attributed low $\mathrm{CH}_{4}$ emissions from tropical peat swamp forests to the nutrient-poor environment, low quality of organic substrates, and the influence of pneumatophores on methane production and oxidation. In addition, most measurements of $\mathrm{CH}_{4}$ emissions from peat are from drained and converted peatlands, where the depth of the oxic horizon is artificially increased, thereby enhancing methane oxidation to $\mathrm{CO}_{2}$. Additional studies are needed that evaluate annual $\mathrm{CH}_{4}$ emissions from intact and drained peatlands under multiple land uses.

Few studies have quantified $\mathrm{N}_{2} \mathrm{O}$ emissions from peat soil, and results indicate that flux rates are very low for forested peatlands (Couwenberg et al. 2010, Murdiyarso et al. 2010). Increases in $\mathrm{N}_{2} \mathrm{O}$ emissions 
have been observed with land-use changes; however, these differences are a fraction of overall $\mathrm{CO}_{2}$ fluxes from associated biomass and peat carbon losses (Murdiyarso et al. 2010). Reported average values of $\mathrm{N}_{2} \mathrm{O}$ fluxes from peatland are $0.10-14.28 \mathrm{~g} \mathrm{~N}_{2} \mathrm{O} \mathrm{m}^{-2}$ $\mathrm{yr}^{-1}$ (Couwenberg 2010). The main drivers of $\mathrm{N}_{2} \mathrm{O}$ emissions from tropical peatland are soil moisture and nitrogen availability, and the highest emissions reported are from drained, heavily fertilised cropland (Takakai et al. 2006). Land uses on peat that require deep drainage and abundant use of nitrogenous fertiliser will likely result in large increases of $\mathrm{N}_{2} \mathrm{O}$ emissions. The presence of nitrogen fixing vegetation (such as Acacia plantations) may also increase $\mathrm{N}_{2} \mathrm{O}$ production; however, data is currently unavailable to assess the influence of nitrogen fixers on net $\mathrm{N}_{2} \mathrm{O}$ emissions.

A limited number of $\mathrm{CO}_{2}$ emission estimates, using net ecosystem exchange measurements from flux towers (eddy covariance technique), have been published for peat swamp forest. Hirano et al. (2007) reported an average net carbon loss of about $4.33 \mathrm{MgC} \mathrm{ha}^{-1} \mathrm{yr}^{-1}$ from drained and selectively logged peat swamp forest in Central Kalimantan, Indonesia in 2002-2004. These results indicate that disturbance of peat forests results in a persistent net negative carbon balance. The impacts of drainage on peat carbon balance can be exacerbated by drought conditions associated with El Nińo (Hirano et al. 2007).

Carbon emissions from disturbed peatlands have also been estimated by linking relationships among $\mathrm{CO}_{2}$ emissions, water table depth, and subsidence (Couwenberg et al. 2010, Hooijer et al. 2010). Assuming peat subsidence increases by $0.9 \mathrm{~cm} \mathrm{a}^{-1}$ for each $10 \mathrm{~cm}$ of drainage, and peat oxidation contributes $40 \%$ to total peat subsidence, Cowenberg et al. (2010) estimated that $\mathrm{CO}_{2}$ flux rates are $9 \mathrm{MgCO}_{2} \mathrm{ha}^{-1} \mathrm{yr}^{-1}\left(2.45 \mathrm{MgC} \mathrm{ha}^{-1} \mathrm{yr}^{-1}\right)$ for each $10 \mathrm{~cm}$ the water table is lowered, to a depth of $50-100 \mathrm{~cm}$. A similar analysis by Hooijer et al. (2010) used $\mathrm{CO}_{2}$ measurements and water table depth, combined with long-term subsidence measurements, to describe soil $\mathrm{CO}_{2}$ emissions as a function of drainage depth, where the peat soil $\mathrm{CO}_{2}$ flux rate increases $9.1 \mathrm{MgCO}_{2} \mathrm{ha}^{-1} \mathrm{yr}^{-1}\left(2.45 \mathrm{MgC} \mathrm{ha}^{-1} \mathrm{yr}^{-1}\right)$ for each $10 \mathrm{~cm}$ of drainage depth. Applying this relationship, the authors suggest $355-855 \mathrm{MtCO}_{2}$ were released from peat decomposition in drained southeast Asian peatlands in 2006. These estimates are for drained peatlands converted to agriculture only, and the relationship of $9.1 \mathrm{MgCO}_{2} \mathrm{ha}^{-1} \mathrm{yr}^{-1}$ for each $10 \mathrm{~cm}$ of drainage depth does not apply to drained forested peatlands. Estimates are also based on total soil $\mathrm{CO}_{2}$ emissions, and likely overestimate the contribution of peat decomposition to net greenhouse gas flux, as autotrophic respiration and carbon inputs to peat are not considered (Murdiyarso et al. 2010). Estimates will be refined as more direct measurements of heterotrophic respiration with simultaneous monitoring of water table depth and subsidence rates become available for multiple land uses.

Finally, a few recent studies have used published carbon stock and flux rates to estimate potential carbon emissions from land-use change on peatlands. Murdiyarso et al. (2010) calculated that the carbon lost from converting peat swamp forest to oil palm plantation is about $405.3 \mathrm{MgC} \mathrm{ha}^{-1}$ over a typical 25 year rotation. Similarly, Hergoualc'h and Verchot (2011) estimated that forest conversion to oil palm results in a loss of $427.2 \mathrm{MgC} \mathrm{ha}^{-1}$ from biomass and peat over a 25 year rotation. Estimates of total carbon emissions from land conversion are restricted to oil palm, due to the scarcity of reliable data on heterotrophic peat oxidation for other land-use types. Total carbon losses from wildfire are also provided for several land-use and cover types (Hergoualc'h and Verchot 2011). Koh et al. (2011) combined remote sensing data with carbon stock and flux estimates to calculate total carbon loss from converting southeast Asian peat swamp forests to oil palm plantations: about $140 \mathrm{MtCis} \mathrm{lost} \mathrm{from} \mathrm{aboveground} \mathrm{biomass}$ with additional annual losses of $4.6 \mathrm{MtC}$ in peat oxidation and $0.66 \mathrm{MtC}$ in foregone sequestration. These calculations apply to the conversion of intact peat swamp forest to oil palm plantations, implying converted lands were recently forested.

\subsection{Issues and gaps}

Many significant issues and knowledge gaps obscure the measurement and monitoring of greenhouse gas emissions from tropical peatlands. Eddy covariance deployments are becoming more widespread in Asia (Kato and Tang 2008), but globally, estuarine mangroves and tropical peatlands remain under represented (Hirano et al. 2007, 2009, Barr et al. 2010). The significance of exports of particulate and dissolved carbon in water are only now gaining acknowledgment (Baum et al. 2007, Moore et al. 2011), and ongoing work in south Florida, 
USA is beginning to clarify waterborne fluxes of carbon in estuarine mangroves (Barr et al. 2010). More experimental work is needed in peatlands and mangroves on possible climate feedbacks (Heimann and Reichstein 2008). In general, very little greenhouse gas flux measurement has been conducted in peat forest that has not been logged or hydrologically disturbed (Rieley et al. 2008). In addition, nearly all carbon dioxide emission measurements from tropical peat describe soil total $\mathrm{CO}_{2}$ fluxes and do not distinguish the contribution of root respiration from total emissions (Couwenberg et al. 2010, Murdiyarso et al. 2010, also see Jauhiainen et al. 2012). Long-term measurements of greenhouse gases are needed in different landuse systems across the tropics to assess interannual variability, refine baseline emission estimates, and evaluate the impacts of land-use change.

Prediction of fire in peatlands is an ongoing area of research that will continue to be improved. Most studies that quantify fire-related carbon emissions from peatlands estimate biomass and peat carbon losses from high intensity wildfires, often during dry years associated with El Nino. Information on emissions from more frequent low-intensity landclearing fires is lacking.

While some studies (cited above) address fluxes of methane and nitrous oxide, the relative importance of these fluxes can only be evaluated if they are made simultaneously with carbondioxide flux measurements; studies that combine these are relatively few. It is necessary to link greenhouse gas fluxes to functional factors, including mean water table depth, land cover and other relevant factors, such as surface soil temperature and fertilisation.

Finally, because of spatial variability and the often complex mosaic of land use and cover on peatlands, more work on scaling up local measurements to landscape and regional levels will considerably improve regional estimates of wetland greenhouse gas fluxes.

\subsection{Recommendations}

Although our understanding about the effects of land-use change on carbon stocks and fluxes in wetland ecosystems leaves much room for improvement, current knowledge is sufficient to assist in management decisions, including broad mitigation strategies for intact peat forest, drained and degraded forest, and agricultural lands on peat. First, avoiding disturbance, deforestation or conversion of intact forest is the most effective way to prevent permanent and large-scale net carbon losses from wetland ecosystems.

In the case of unmanaged, drained and degraded peat lands, a critical task is to reduce fire risk. Hydrological restoration, assisted regeneration and forest regrowth may be the best practices for reducing the vulnerability of peatlands to fire, and more experimentation is needed to assess the efficacy of these management options. Since fire is commonly used to clear land, prepare land between rotations, and burn residues, it is also important to work with the local communities to identify alternatives to fire use. More education is also necessary to prevent accidental fires from negligence. Converting degraded land to agriculture, establishing a clear economic stake in fire prevention, is also possible, but strong partnerships among industry and local communities are necessary (Suyanto et al. 2004). In the past, fire has been used to protest or draw attention to land tenure disputes; therefore resolving these social issues is also necessary to reduce fire risk. It is important to bear in mind that peat substrate oxidation will continue from drained, converted peatlands even if fire is prevented, resulting in high net carbon emissions.

Assuming that the peat decomposition process would be mitigated by rewetting, carbon emissions and subsidence could somewhat be reduced in existing agricultural plantations by keeping the water table as high as possible. However, the relationship described by Couwenberg et al. (2010), in which subsidence increases with drainage depth, is valid only for drainage depths lower than $50 \mathrm{~cm}$-which is a minimal drainage depth for many agricultural uses. Therefore, further research on how decreased drainage depth could reduce peat decomposition is required, notably for drainage depths deeper than $50 \mathrm{~cm}$, such as in oil palm plantations. In addition to controlling drainage, minimal use of nitrogen fertilisers will restrain nitrous oxide emissions, and potentially peat decomposition as well.

Methods for studying carbon dynamics in peatlands and mangroves can clearly be improved in several areas. First, using standardised methods and protocols would greatly improve the comparability 
of results between studies and reduce confusion. Standardised methods would be required, in particular, for covering the high spatial heterogeneity of soil surface emissions in forests (Hirano et al. 2007) and excluding root respiration from closedchamber flux measurements of $\mathrm{CO}_{2}$. Clear protocols would also help to ensure that methods are applied uniformly by different scientists working within the same project.

Meaningful analyses of data available in the literature would benefit greatly from better site descriptions and land-use histories. Standards should include a list of relevant metadata to allow interpretation of results, such as a descriptive history of disturbance, drainage and fertilisation. Within Indonesia, work has been most intensive near Sebangau in Central Kalimantan and around Jambi, Sumatra. Other geographical areas have been less studied; in particular, West Papua. Agricultural lands are important targets for study, requiring cooperation from private land owners for site access, which can be difficult.

Finally, research efforts could be much improved by increased funds and personnel with combined field readiness and technical skills, both of which are needed for successful fieldwork. Technical limitations also need to be addressed, such as the availability of analytical equipment to measure trace gas fluxes (such as gas chromatographs) in developing regions. Stronger institutional support from local universities and research centres is needed to sustain additional and longer term studies on greenhouse gas emissions in tropical peatlands. 


\title{
3. Ecosystem carbon stocks and land-use and land-cover change in tropical wetlands
}

\author{
Matthew Warren, J. Boone Kauffman, Cahyono Agus, Iswandi Anas, Gusti Anshari, Laura D'Arcy, Fabien Garnier, Deddy \\ Hadriyanto, Bambang Hero Saharjo, Simon Husson, I Wayan S. Dharmawan, Haruni Krisnawati, Maswar, Hubertus \\ Matanubun, Rumi Naito, Sebastian Persch, Nur Hygiawaty Rahayu, Zoe Ryan, Sulistyo A. Siran, Solichin, Taryono \\ Darusman, Peter J. van der Meer and Iwan Tri Cahyo Wibisono
}

\subsection{Background}

Historically, wetlands have been valued for their numerous ecosystem services and hydrological, ecological and habitat functions. Since the early 1980 s, a small number of wetland scientists have also recognised their additional value as global carbon sinks (De la Cruz 1982, 1986, Maltby and Immirzi 1993, Sorenson 1993, Page et al. 2011). Recently, tropical wetlands have entered into international policy dialogue for their important role in the global carbon cycle and climate adaptation and mitigation strategies.

When wetlands are drained, aerobic conditions stimulate organic matter decomposition and former wetland carbon sinks can emit large amounts of stored carbon into the atmosphere as $\mathrm{CO}_{2}$ (see Chapter 2; De la Cruz 1986, Cowenberg et al. 2010). Wetlands in the humid tropics are particularly sensitive to rapid carbon oxidation and loss from disturbance because the environmental controls on decomposition (temperature and moisture) are optimum. In addition to drainage, tropical wetlands emit large amounts of $\mathrm{CO}_{2}$ and other greenhouse gases when burned. Fire spreads belowground through the surface layer of the peat (Ballhorn et al. 2009). Carbon lost from burning soil organic matter contributes to much higher greenhouse gas emissions per hectare than from aboveground biomass alone. The vulnerability of tropical wetland carbon pools to disturbance, and the numerous ecosystem services they provide should identify them as potential targets for mechanisms to reduce emissions from deforestation and degradation, such as REDD+ (reducing emissions from deforestation and forest degradation, and enhancing forest carbon stocks in developing countries).
Tropical wetland carbon pools are among the highest reported for any vegetation type on Earth. Chimner and Ewel (2005) estimated 330.0-775.5 Mg/ha of belowground peat carbon for forests on Kosrae, Federated States of Micronesia; Murdiyarso et al. (2009) reported 1077.3 MgC/ha for riverine peat forests in Tanjung Puting, Indonesia; and Jaenicke et al. (2008) estimated up to $3130.5 \mathrm{MgC} /$ ha for the Sebangau peat dome in Indonesia. The global average for all tropical peatlands was calculated as $2009 \mathrm{MgC} /$ ha by Page et al. (2011). In a recent survey of mangrove forests across the Indo-Pacific region, Donato et al. (2011) reported average ecosystem carbon stocks of $1023 \mathrm{MgC} / \mathrm{ha}$. For both peatlands and mangroves, up to $98 \%$ of the total ecosystem carbon is stored belowground.

Few attempts have been made to extrapolate tropical wetland carbon storage to regional or global scales. The best estimates have been produced by Page $e t a l$. (2011) for peatlands, and Donato et al. (2011) for mangroves. Page et al. (2011) estimate the size of the global tropical peatland carbon pool at 88.6 PgC, with $77 \%$ occurring in southeast Asia. Mangroves may contribute an additional 4-20 PgC globally (Donato et al. 2011). These estimates are based on available data, which are lacking for many of the major tropical wetland regions of the world. Minor changes in assumptions of peat depth, bulk density, and carbon concentration produce large changes in overall carbon storage estimates, since belowground carbon pools are scaled volumetrically. The precision of regional and global estimates of carbon pools in tropical organic soils will continue to improve as data becomes available for wetland forests that vary in geographic location, age, peat depth, structure and composition. 


\subsection{Land-use change}

Approximately $47 \%$ of the world's tropical peatlands (Page et al. 2011) and 23\% of its mangroves (Giri et al. 2011) occur throughout the Indonesian archipelago. Indonesia's wetland forests are under considerable pressure from land-use and land-cover change (LULCC), evidenced by high deforestation rates and fire occurrence since 1980s (Langner et al. 2007, Miettinen and Liew 2010a, Miettinen et al. 2011). Prominent land uses on organic wetland soils include agriculture (oil palm, rice, sago palm and vegetable crops), silviculture (timber estates, rubber plantations) and aquaculture (shrimp and fish ponds; largely confined to converted mangroves). These land uses can be broadly categorised into forestry, nonforestry and stand improvement (Table 3.1). Stand improvement refers to forests that are managed to increase yields of harvested forest products, such as sago palm. Wetland forests are also converted for settlements, land speculation and infrastructure development. These various land uses result in multiple types of land cover on wetland soils. Selective and intensive logging and land conversion result in forest cover and species losses and forest areas are left in various states of degradation.

Regrowth and secondary succession occurs in some areas, however degraded sites usually succumb to development. Drainage and burning produces open areas dominated by grasses, ferns and shrubs.

Peat swamp forest conversion to plantation and agricultural uses often follows a typical progression:
1. intact mature forests are selectively logged;

2. drainage canals cut for logging provide further access to the forests, and heavier (often commercial) timber harvesting occurs;

3. the administrative classification of the forest area changes, permitting forest removal;

4. forest removal;

5. peat drainage and reduced canopy cover increase surface temperatures and reduce moisture, which facilitates burning. The remaining vegetation is slashed and burned;

6. more canals are cut for massive drainage, and the land is prepared for plantation establishment (often including heavy machinery);

7. plantation species are established on drained and graded peat soils.

Significant losses of above- and belowground carbon stocks occur at each stage of land conversion, and large amounts of carbon are emitted into the atmosphere as $\mathrm{CO}_{2}$ from biomass burning and peat oxidation. Additional carbon losses, via dissolved and particulate organic carbon export, are assumed to be high, but have not yet been quantified.

Generalisations about mangrove alteration are not as well defined. Historically, mangrove forests were often cut for fuel, tannin or charcoal production, and domestic uses (De la Cruz 1982). Mangroves were also lost to paddy rice cultivation and coconut palm plantations. Current trends indicate shrimp and fish

Table 3.1. Examples of land uses occurring on tropical wetland soils in Indonesia

\begin{tabular}{|c|c|c|c|}
\hline Land-use category & Land use & Purpose of land use & Land cover \\
\hline \multirow[t]{2}{*}{$\begin{array}{l}\text { Forest manipulations } \\
\text { and conversions }\end{array}$} & $\begin{array}{l}\text { Selective, moderate and heavy } \\
\text { logging }\end{array}$ & Timber extraction & $\begin{array}{l}\text { Forest in various states of } \\
\text { degradation }\end{array}$ \\
\hline & $\begin{array}{l}\text { Timber estate, Acacia and rubber } \\
\text { plantations }\end{array}$ & $\begin{array}{l}\text { Pulp production, latex } \\
\text { production }\end{array}$ & Plantation monoculture \\
\hline Stand improvement & Non-timber forest products, sago & Forest products & Managed natural forest \\
\hline \multirow[t]{6}{*}{ Conversion to non-forest } & Cropland & Agriculture & $\begin{array}{l}\text { Oil palm, rice, sugarcane, } \\
\text { fruits and vegetables, etc. }\end{array}$ \\
\hline & Artificial ponds & Aquaculture & Shrimp or fish ponds \\
\hline & Rural homesteads, villages & Settlements & Small homes \\
\hline & Cleared land to be developed & Speculation & Shrubs/grasses \\
\hline & Roads, bridges, dykes, etc. & Infrastructure & Concrete infrastructure \\
\hline & Towns, coastal development & Development & Concrete infrastructure \\
\hline
\end{tabular}


aquaculture are important threats to mangroves in Indonesia and elsewhere (Alongi 2002, Duke et al. 2007). Mangrove forest is typically cleared, and dykes are constructed using the underlying peat soils. Pond areas are drained as part of the preparation. Aeration of soils in embankments and the empty ponds results in increased heterotrophic oxidation and $\mathrm{CO}_{2}$ emissions. On acid sulphate soils, the oxidation of pyrite also results in soil acidification. The average productive life span of shrimp ponds is only 6 years, after which the pond is abandoned and new areas of mangroves must be cleared.

\subsection{Carbon stock changes associated with land-use changes}

The major carbon stocks of tropical wetland forests have been quantified for several sites across Indonesia, however above- and belowground pools have seldom been measured simultaneously. Country-wide carbon stock estimates for wetland forests are still lacking, and a greater understanding of carbon stock variability across different wetland forest types is needed. Furthermore, methodological differences among studies limit data comparability. For example, the carbon content of peat soil has been determined by loss on ignition, wet combustion (WalkleyBlack), and induction furnace methods, and different allometric equations have been employed to estimate aboveground biomass.

The large carbon stocks associated with tropical wetland forests are the result of net positive carbon balance over thousands of years. The conversion of these forests to alternate land uses is well known to cause large carbon losses via several pathways (Hergoualc'h and Verchot 2011). Large carbon losses occur from aboveground biomass harvest and combustion from fire, heterotrophic oxidation of drained peat, and export as dissolved organic carbon (DOC) and particulate organic carbon (POC). Carbon lost from aboveground biomass harvest and burning can be considered as instantaneous carbon oxidation and emission to the atmosphere, since only an insignificant fraction of harvested carbon is conserved in long lived forest products. Of particular concern are carbon emissions from peat fires, which are often associated with land-use change. For example, Page et al. (2002) estimated that $0.81-2.57 \mathrm{GtC}$ were emitted to the atmosphere from Indonesian peatlands during the 1997 fire season. Similarly, Ballhorn et al. (2009) estimated that $0.11-0.39 \mathrm{GtC}$ were emitted from burning
Indonesian peatlands in 2006 (calculated from the $87-295 \mathrm{MgC} /$ ha lost from peat fires within their study area).It is worthwhile to note that the upper estimates of peat carbon losses from fire are based on intense fires in intact or partially drained forests, and also include areas impacted by the spread of unintentional fire (as acknowledged by Ballhorn et al. 2009). Reliable estimates of peat carbon losses from deliberate brush clearing fires set by smallholders on previously degraded lands are unavailable at this time.

Heterotrophic oxidation also results in large carbon fluxes to the atmosphere. The magnitude and fate of carbon export as DOC and POC is largely unknown for tropical wetland forests in Indonesia and elsewhere. No land-use change was considered to increase carbon stocks, other than forest restoration or natural regeneration, accompanied with blocked artificial drainage, rewetting of the peat and limited replanting efforts. However, data is lacking with which to evaluate the magnitude of carbon gains from forest regrowth and hydrological restoration.

\subsection{Knowledge gaps}

Many research opportunities exist to better understand carbon stock dynamics in tropical wetland forests. These include both broad areas of research and specific components of carbon stock assessment, such as:

- Allometric equations for above- and belowground biomass

- Allometry of plantation species and other life forms

- Carbon balance

- Carbon stocks in primary forests (nationwide)

- Carbon stocks in other land uses

- Carbon sequestration/accumulation rates

- Climate adaptation

- Experimental approach/design

- Linkages with biodiversity

- Linkages with ecosystem function

- Linkages with hydrological processes

- Linkages with ecosystem services

- Peat soil properties (density, depth, chemistry, hydraulics etc.)

- Peat volume calculation

- Standardised methodologies

- Terminology and peat classification 


\subsection{Challenges to carbon stock and land-use and land-cover change assessment}

Assessing Indonesia's wetland forest carbon stocks and how they are affected by LULCC is a formidable task. Numerous challenges need to be overcome to achieve a better understanding of the drivers of LULCC and associated carbon stock changes. In addition to the technical hurdles that must be overcome to ensure data are high quality and comparable, other institutional challenges exist, which complicate the ability of many scientists working under different organisations to adequately address research needs.

\subsubsection{Funding}

Accurate remote and ground based data acquisition requires considerable economic and human resources. Lack of sufficient funding for equipment, transportation, salaries, data analysis and laboratory materials limits the capacity of researchers to acquire the data necessary to answer research questions. Funding challenges also extend to the institutional level, where support is needed for infrastructure, networking and collaborative efforts. Improved communication among universities is needed to develop regional and national research synergies, limiting redundancies and geographic bias. Finally, human resources need to be developed, and capacity building is required at all levels of scientific research including temporary field assistants, students, technicians, senior scientists and institutions.

\subsubsection{Facilities and laboratories}

Most of the carbon stored in tropical wetland forests is contained in their organic soils. Laboratory facilities are required for even minimum preprocessing of soil samples to accurately measure carbon density. The lack of suitable facilities and analytical equipment is identified as a major concern of scientists studying the dynamics of carbon stocks and LULCC. Existing equipment must also be maintained and calibrated, and consumables, lab supplies and materials are frequently unavailable in less developed regions. In addition, basic infrastructure such as sufficient and reliable electricity and plumbing are lacking in many laboratories. Long-term funding mechanisms need to be identified to assist in the sustainability and growth of research laboratories in many developing areas.

\subsubsection{Plot security}

Ensuring the integrity of research plots and avoiding accidental and intentional plot destruction is essential to the success of any research effort. Many wetland scientists have encountered security problems, including theft, vandalism and fire. Issues with plot security often require research to be conducted in controlled access areas such as national parks or reserves. Measures can be taken to avoid security issues such as socialisation with local residents and adequate informative signs. Security should always be considered in the site selection process.

\subsubsection{Publications}

Communication is an important aspect of the scientific process. Improved access to peer reviewed scientific literature is necessary for students and scientists to gain the background knowledge needed to address research gaps and formulate new research ideas. Language barriers need to be overcome to increase Indonesian scientific output to international peer reviewed journals, thus raising the awareness and funding potential of local efforts.

\subsubsection{Methods}

Standardised methodology and the ability to use the latest technology available for scientific research are necessary to advance our knowledge of carbon stocks and LULCC in Indonesia. Robust methodology and strong experimental design are essential for good quality research. Increased knowledge about sample strategies and standard methods to assess carbon stock and LULCC are needed to ensure resources are well spent to achieve the desired research objectives.

\subsubsection{Links to policymakers}

Scientific research must be supported by all levels of government, yet scientists and policymakers are often disconnected. Bridging the gap between them is critical for science-based policy to be enacted to improve carbon management. Stronger linkages are therefore necessary to inform policymakers about the relevance of ongoing research in the wetland forests of Indonesia. 


\subsection{Emerging issues and recommendations}

Several other issues affect wetland carbon stock and LULCC research. Issues relating to land tenure and entitlement need to be resolved. The occupation and exploitation of tropical wetland forests, particularly mangroves, is not well controlled. Laws preventing certain forms of exploitation are absent. Existing laws against illegal wetland deforestation are not implemented or enforced. Laws are not harmonised across different levels of government, and many district or provincial policies are not in line with those of the central government. Good governance is needed at all levels, policies need to be better coordinated, and many laws need to be revised. Improvement to these aspects of public policy could help mitigate the large carbon emissions from wetland forests. The issues of mainstreaming carbon payments under REDD+ type projects, food security and education are also important aspects of avoided deforestation programmes.

The following list includes priorities and suggestions for future research on LULCC and carbon stocks in Indonesian wetland forests:

- The relevance of science on the dynamics of tropical wetlands in the context of climate change, adaptation and mitigation is in need of more recognition and support at local, national, and international levels. Multi- and interdisciplinary studies are needed to address these global issues.

- Mitigating forest degradation and ecosystem restoration are perhaps the most effective forms of adaptation. Social development must be considered along with habitat changes.
- Establishment of a permanent plot network, development of standardised protocols and the creation of a centralised database is necessary to measure and monitor carbon stock dynamics in tropical wetland forests. This entails significant investment in education and infrastructural support.

- Resolving regional planning issues is necessary to curb the current rates of deforestation and prevent future carbon losses. Climate change adaptation and mitigation should be included in regional planning efforts.

- Integrated wetland management at large and appropriate spatial scales must be considered. The high hydrological connectivity of tropical wetland forest ecosystems implies that management upstream has a large impact on the forests downstream.

- Rehabilitating and restoring degraded wetlands to enhance or recover carbon stocks or net sequestration should be implemented before systems collapse to unrecoverable states due to the combination of unsustainable land use and climate change.

- Biodiversity and other ecosystem services should be important considerations in adaptation and mitigation strategies that are targeted towards carbon stocks of wetlands. Community participation at early planning stages, and an understanding of expected outcomes from carbon conservation strategies, are critical for the success of programmes aimed at conserving carbon stocks and ecosystem services. 


\section{Ecosystem modelling of tropical wetlands}

Kristell Hergoualc'h, Steve Frolking, Pep Canadell, Stephen Crooks, Mark Harrison, Hans Joosten, Sofyan Kurnianto and Carey Yeager

\subsection{Background}

Modelling is essential for enhancing our understanding of the functioning of tropical wetland ecosystems, and for simulating future trajectories and testing for system thresholds. Anthropogenic activities such as drainage and land-use change can be integrated in models and their impacts on fluxes of greenhouse gas concentrations simulated. Models can also be used to test the response of peatlands and mangroves to climate extremes, variability and change, and to estimate reference levels and greenhouse gas emissions scenarios in the framework of climate change mitigation projects such as REDD+. In coastal settings, models are used to explore wetland resilience to sea-level rise. Finally, models can also be developed to support the decision making process by providing policyrelevant information on the consequences and trade-offs of adopting different management and climate scenarios.

\subsection{State of the science}

Different types of models of varying complexity exist but their applicability to tropical wetland ecosystems varies greatly. A number of allometric equations have been developed to quantify aboveground carbon stocks in tropical mangroves (Saenger 2002, Chave et al. 2005, Smith and Whelan 2006, Komiyama et al. 2008, Kauffman and Cole 2010, Kauffman and Donato 2011) and oil palm (Corley et al. 1971, Khalid et al. 1999, van Noordwijk et al. 2010) or Acacia plantations (Hiratsuka et al. 2003, Heriansyah et al. 2007). Fewer allometric relationships for estimating aboveground carbon stocks in virgin tropical peat swamp forests have been developed (Manuri et al. 2011). Three individual-based models (FORMAN, KIWI and MANGRO) describe neotropical mangrove forest dynamics (Berger et al. 2008).
Tropical wetlands have a large portion of their carbon stores belowground. Large carbon losses arising from anthropogenic activities and climate change are expected to come from this pool in particular (Crooks et al. 2011). However, few models have been developed that simulate carbon and nutrient dynamics in tropical peats and carbon rich mangrove soils. Several hydrological models are available for simulating water dynamics in tropical peats (e.g. SIMGRO -SIMulation of GROundwater flow and surface water levels [Wösten et al. 2006]).

Some simple empirical relationships have been developed for tropical peatlands between water table depth and subsidence rates, between $\mathrm{CO}_{2}$ fluxes arising from peat decomposition and water table depth or $\mathrm{pH}$ or ash content, and between $\mathrm{pH}$ or peat temperature and peat mineralisation and $\mathrm{CH}_{4}$ production (Murayama and Bakar 1996a, 1996b, Miyajima et al. 1997, Couwenberg et al. 2010, Hooijer et al. 2010). A more complex model based on ecophysiological studies of oil palms planted on peatlands simulates carbon sequestration and greenhouse gas emissions associated with oil palm cultivation and land-use change in peatlands (Henson 2009).

Two process-oriented models, the Holocene Peat Model (HPM)(Frolking et al. 2010) (Figure 4.1) and Estimation of Carbon in Organic Soils Sequestration and Emissions (ECOSSE) (Smith et al. 2010) (Figure 4.2), both developed for temperate, boreal peatlands, may be appropriate for use in tropical conditions. The HPM model is currently being parameterised using data from tropical peatlands of Jambi, Sumatra.

Regarding mangroves, the Marshy Equilibrium Model (MEM2) (Morris et al. 2002) simulating sedimentation and carbon accumulation in 


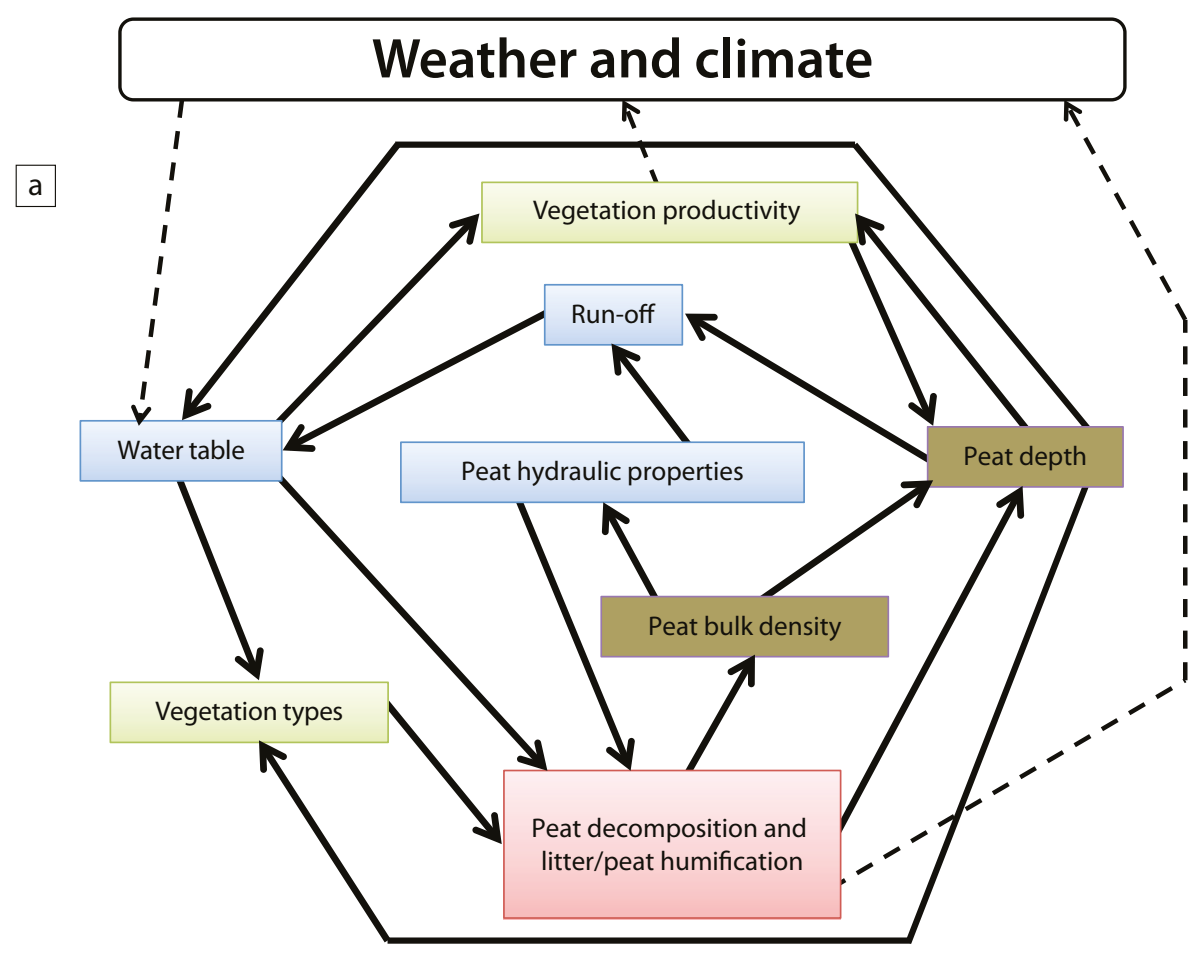

b

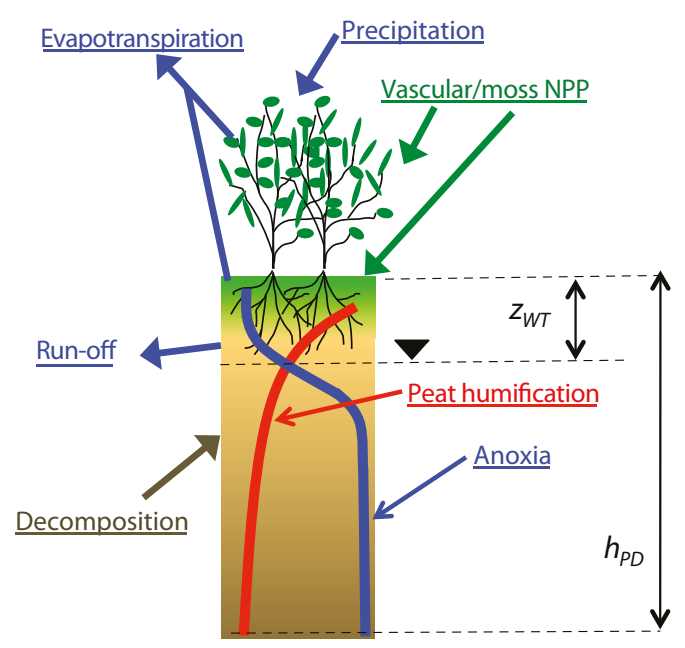

Figure 4.1. The Holocene Peat Model (HPM) that simulates the interaction of carbon and water and vegetation dynamics in peatland (a), and calculates the annual peatland carbon and water balance in one (vertical) dimension (b), where NPP is Net Primary Production

Source: Frolking et al. 2010

soil, has been developed for temperate coastal wetlands of the United States and could be further used in tropical mangrove ecosystems. ${ }^{1}$ The DeNitrificationDeComposition model (DNDC) is

1 This model is currently under expansion by a working group convened at the National Center for Ecological Analysis and Synthesis (http://www.nceas.ucsb.edu/featured/callaway). also being tested in converted marshlands (rice fields) (Huang et al. 2010) and converted mangroves of Trinidad and Tobago (World Bank 2008).

In coastal settings, wetlands will respond to sea-level rise by building upwards and migrating landwards. The resilience of wetlands to sea-level rise will depend on a combination of mineral supply and root 
material production to build soil matter to balance rising water levels. A number of $1 \mathrm{D}$ and $2 \mathrm{D}$ models have been developed and tested to simulate wetland response to sea-level rise in temperate systems but have yet to be applied in tropical settings (e.g. Orr et al. 2003, Reyes et al. 2003).

Datasets of field and laboratory observations are required for developing, parameterising, calibrating and validating models. Although a large amount of data has been collected in tropical peatlands, too much remains unpublished in peer-reviewed international journals. Well-studied sites, with available data for model development and testing, need to be identified. Improvement of dataset quality requires capacity building. It is suggested that joint field and modelling efforts, and collaborative partnerships are established for the collection of future datasets, with institutions such as the Ministry of Forestry, Indonesian Institute of Sciences (LIPI), Ministry of Research and Technology, Ministry of Environment and Ministry of Agriculture.

In the models, plant inputs enter the soil as resistant plant material (RPM) and decomposable plant material (DPM), and decompose into 'biomass' or active organic matter (BIO) and 'humus' or more slowly turning over soil organic matter (HUM). Organic matter that has become inert (IOM) is assumed to not contribute to the decomposition processes. Losses of carbon and nitrogen from the soil are gaseous $\left(\mathrm{CH}_{4}, \mathrm{CO}_{2}, \mathrm{~N}_{2} \mathrm{O}, \mathrm{N}_{2}\right.$ and $\left.\mathrm{NH}_{3}\right)$ and in

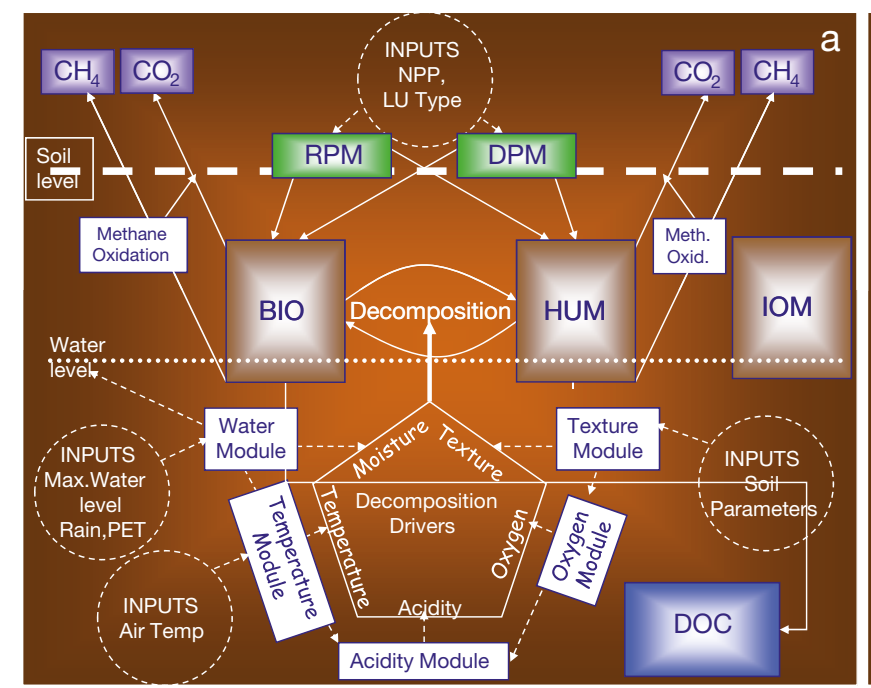

solution (dissolved organic carbon [DOC], dissolved organic nitrogen $[\mathrm{DON}]$ and leaching nitrate nitrogen). Solid arrows indicate flow of material; dashed arrows indicate influence, LU: Land-use, NPP: Net Primary Production, and PET: Potential Evapotranspiration.

\subsection{Priorities and recommendations}

To conclude, the following priorities were identified:

- Empirical models should be developed for full carbon accounting for REDD+ projects in tropical freshwater peatlands, mangroves and coastal wetlands.

- Biogeochemistry models for tropical freshwater peatland and mangrove ecosystems should be developed and tested, utilising existing datasets, and in collaboration with ongoing and planned field studies. Several models have been mentioned above (e.g. ECOSSE, HPM, MEM2, DNDC), but this list is by no means exhaustive and other initiatives are encouraged.

- Decision support tools should be developed for policy makers that facilitate exploration of different climate change, land-use and disturbance scenarios, along with tools that can assess multiple ecosystem services in addition to carbon, such as biodiversity, food security, water resources, and trade-offs between these services (e.g. Koh and Ghazoul 2010).

Figure 4.2. Structure of the carbon (a) and nitrogen (b) components of ECOSSE

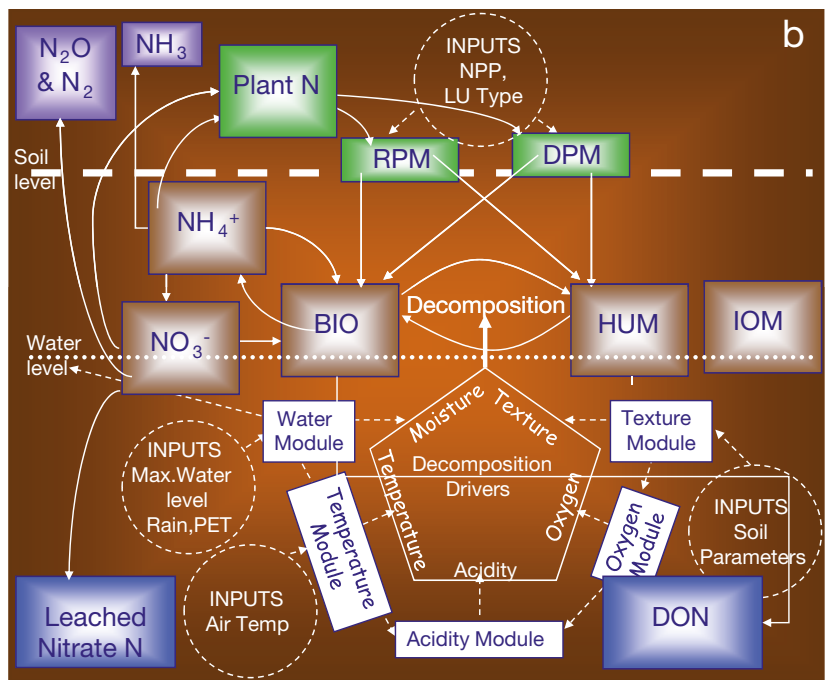




\title{
5. The use of remote sensing to monitor land- use and land-cover change in tropical wetlands
}

\author{
Martin Herold, Faiz Rahman, Morten Rossé, Ruandha Sugardiman, Hendrik Segah, Bill Rush, Temilola Fatoyinbo, Florian \\ Siegert, Wim Nursal, Yasumasa Hirata, Erika Romijn, Joseph Hutabarat, Jukka Miettinen, Mirna Rumapea, Fauzana, \\ Kazuyo Hirose, Agus Suratno, Eko Ridarso and Micah Fisher
}

\subsection{Background}

Remote sensing approaches are of fundamental importance in monitoring wetlands status, dynamics and changes. For the majority of developing countries, the analysis of remotely sensed data from satellites and other platforms is often the only practical and objective approach for measuring change in forests and wetlands. The earth observation community advocates this approach and has provided technical guidance on how to use spacebased earth observations for studying trends and patterns in tropical land-use change and associated carbon emissions (GOFC-GOLD 2010). In particular, remote sensing offers unique monitoring opportunities, in the assessment and comparison of historical and future rates of change in a consistent, transparent and cost-effective manner. Of particular interest is tracking the effects of human activities on wetlands (i.e. land-use change, degradation and wetland drainage) and the impacts of climate change and related vulnerabilities, such as changes in wetland condition and extent due to sea-level rise and changed water regimes.

Many types of remote sensing data are available for wetland studies. Archived historical satellite data are available globally (i.e. NOAA-AVHRR, Landsat, MODIS, MERIS). The continuity of this data allows consistent and continuous monitoring programmes to be established for local, national and global purposes. The experiences of different groups and fields of application have been documented and provide insights into the potential and limitations of using remote sensing techniques in wetlands monitoring and analysis.

This chapter provides an overview and assessment of the current status of Indonesia's wetlands and offers recommendations on the use of remote sensing. The assumptions and results presented here are derived from the dedicated breakout group discussions that included international, national and local experts.

\subsection{What can be monitored?}

While human activities and climate change alter wetlands, different variables can benefit from the use of remote sensing approaches for monitoring and assessment. The most important variables are presented in Table 5.1.

Different types of monitoring approaches are available and can be used to derive wetland data. They differ in the types of remote sensing (and ground) data used, and the data analysis and interpretation approaches.

\subsection{How is remote sensing being used to monitor wetlands?}

Several actors are already using remote sensing approaches for wetland monitoring, including:

- governmental and nationally-mandated monitoring institutions;

- research groups and universities;

- private companies and industry providing monitoring services;

- nongovernmental institutions.

The following examples of remote sensing approaches to wetlands monitoring have been drawn from presentations delivered at the Workshop on Tropical Wetland Ecosystems of Indonesia, Bali. Appendix 1 also provides an overview of remote sensing activities for wetland monitoring. 
Table 5.1. Key wetland variables that can benefit from remote sensing approaches, and related observation parameters

\begin{tabular}{ll}
\hline Variable & Observation parameter \\
\hline Landcover (land-use) and change & Areas affected by: \\
& - deforestation \\
& - degradation \\
& - deforestation and afforestation \\
Biomass and carbon stocks and & Several indicators used in estimating biomass and carbon (i.e. vegetation \\
change (aboveground) & height, type and cover density) \\
Soil carbon stocks and change & Peat depths (local elevation) and elevation changes \\
Fire & Active fire, burnt area, fire intensity and severity, radiative energy and recovery \\
& after burning \\
Wetland types and biodiversity & Extent of different types of wetlands (i.e. peatlands and mangroves), \\
biodiversity and identification of some species (also submerged) & Water level/status (also sea level), flooding (cycles) and extreme events \\
Wetland hydrological dynamics & Estimation of $\mathrm{CO}_{2}$ concentrations in the atmospheric column \\
Atmospheric carbon &
\end{tabular}

\subsubsection{Land cover and change}

Remote sensing is being used to detect changes in land cover, with an emphasis on deforestation. Few efforts are dedicated to monitoring land-use change in wetlands, but large area studies have been conducted; including one performed by CRISP (Figure 5.1). This study has been using freely available Landsat and MODIS data to map two decades of loss in Southeast Asia's peat swamp forests.
Other studies have made more local assessments and utilised time series images (Figure 5.2) (e.g. Rahman et al. in review).

\subsubsection{Biomass and carbon stocks (aboveground)}

Several indicators can be derived from remote sensing to help estimate biomass and carbon stocks. These

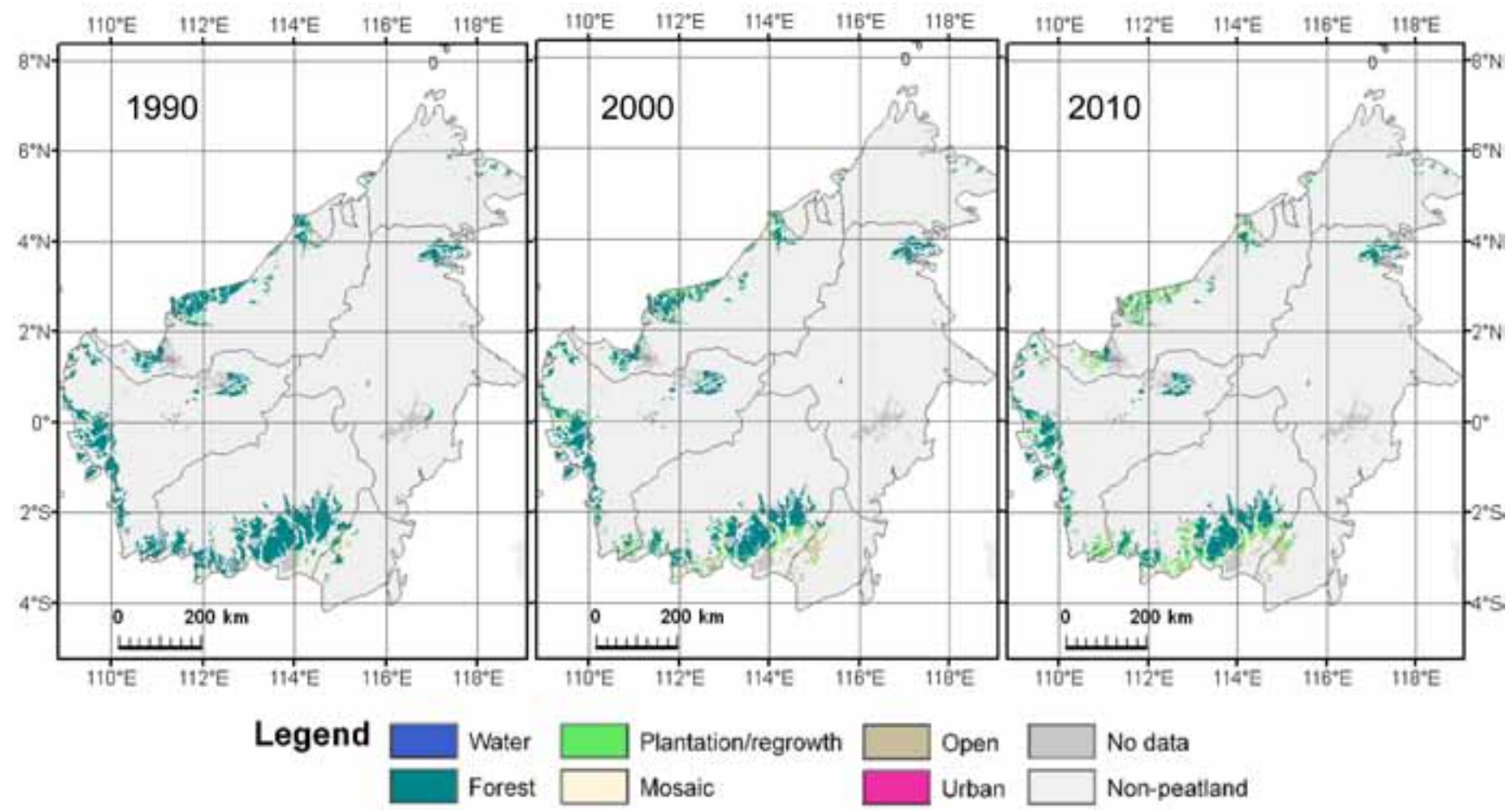

Figure 5.1. Peatland land-cover distribution in Borneo 1990-2010 


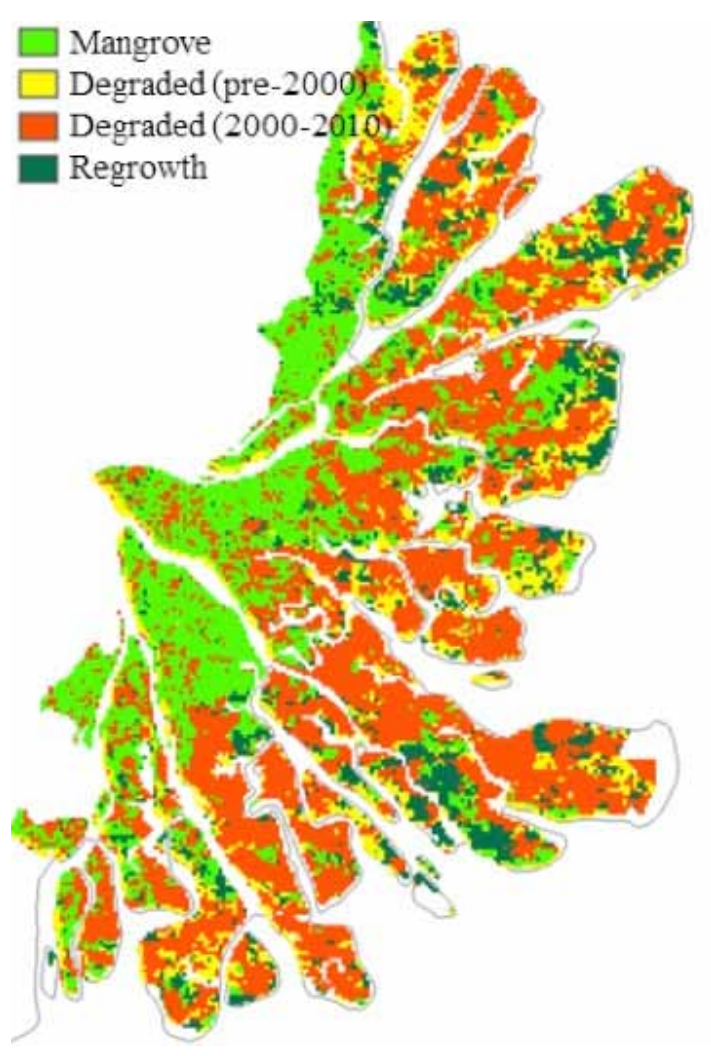

Figure 5.2. Land-use change of mangroves in the Mahakam delta in East Kalimantan, Indonesia, 2000-2010

Note: Four different states of land use were derived using highfidelity time series of MODIS imagery, at $250 \mathrm{~m}$ spatial resolution and quarterly time intervals.

Source: Rahman et al. in review include vegetation height, type and cover density. LIDAR approaches have proven most useful for estimating vegetation height. New global datasets are emerging based on ICESAT-GLAS data (Figure 5.3). Other studies have used local and regional remote surveys to estimate vegetation biomass (i.e. Hirata et al. 2009).

\subsubsection{Fire and soil carbon stock change}

Remote sensing approaches have been extensively used to map active fire, burnt area, fire intensity and severity, radiative energy, and vegetation recovery after burning. Fires in peatlands can also effect the soil carbon pool; a study by Ballhorn et al. (2009) has demonstrated the use of fire observations and LIDAR data to assess burnt area and the changes in peat depths following a fire event (Figure 5.4).

\subsection{What should be improved?}

Detailed discussions focused on existing gaps in using remote sensing for the monitoring of wetlands and related climate change mitigation and adaptation initiatives. Table 5.2 gives an overview of the gaps identified for various observation variables.

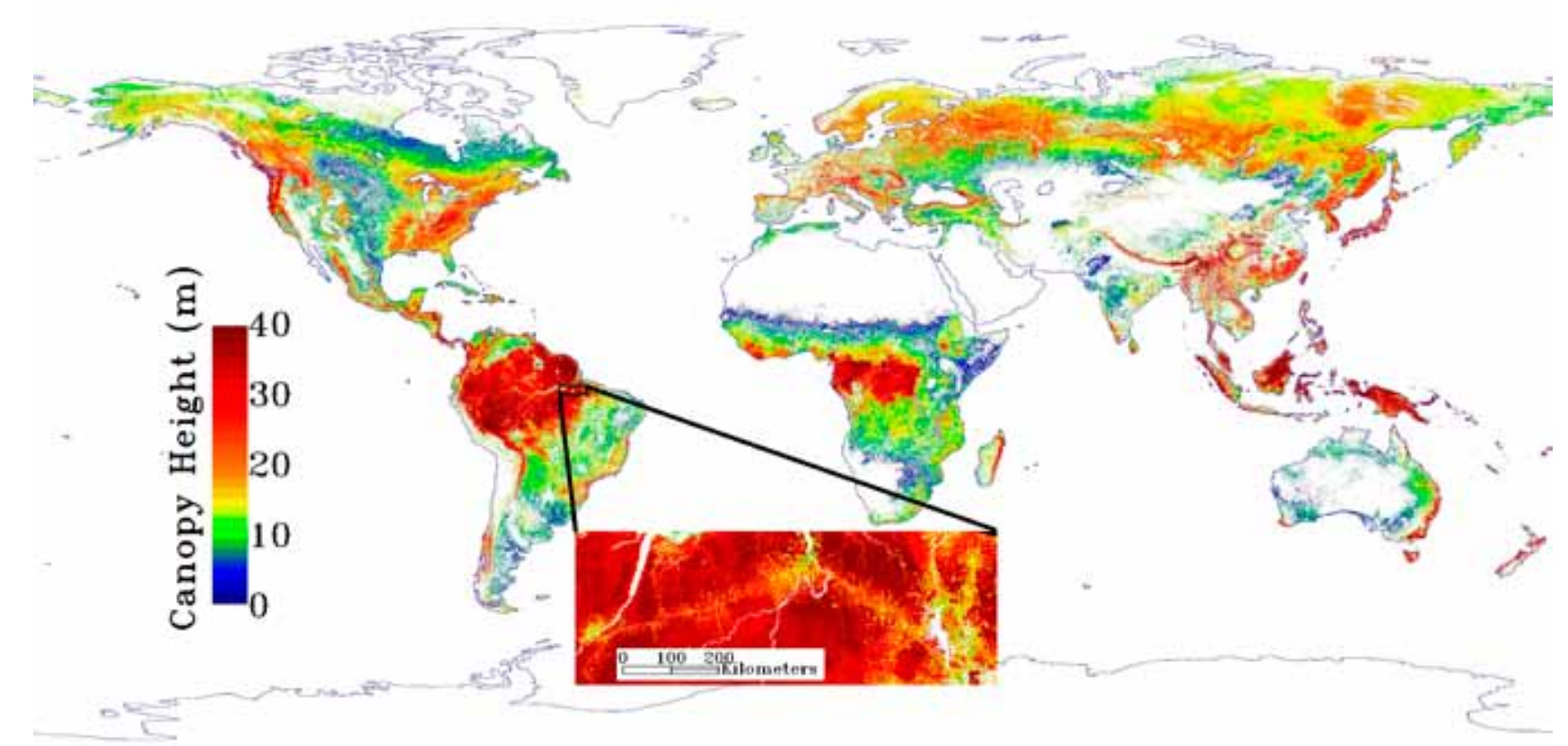

Figure 5.3. Wall-to wall map produced by modeling GLAS points with a regression tree approach

Note: The inset shows a disturbance gradient in the Amazon.

Data also available at http://lidarradar.jpl.nasa.gov.

Source: Simard et al. 2011, reproduced by permission of American Geophysical Union 

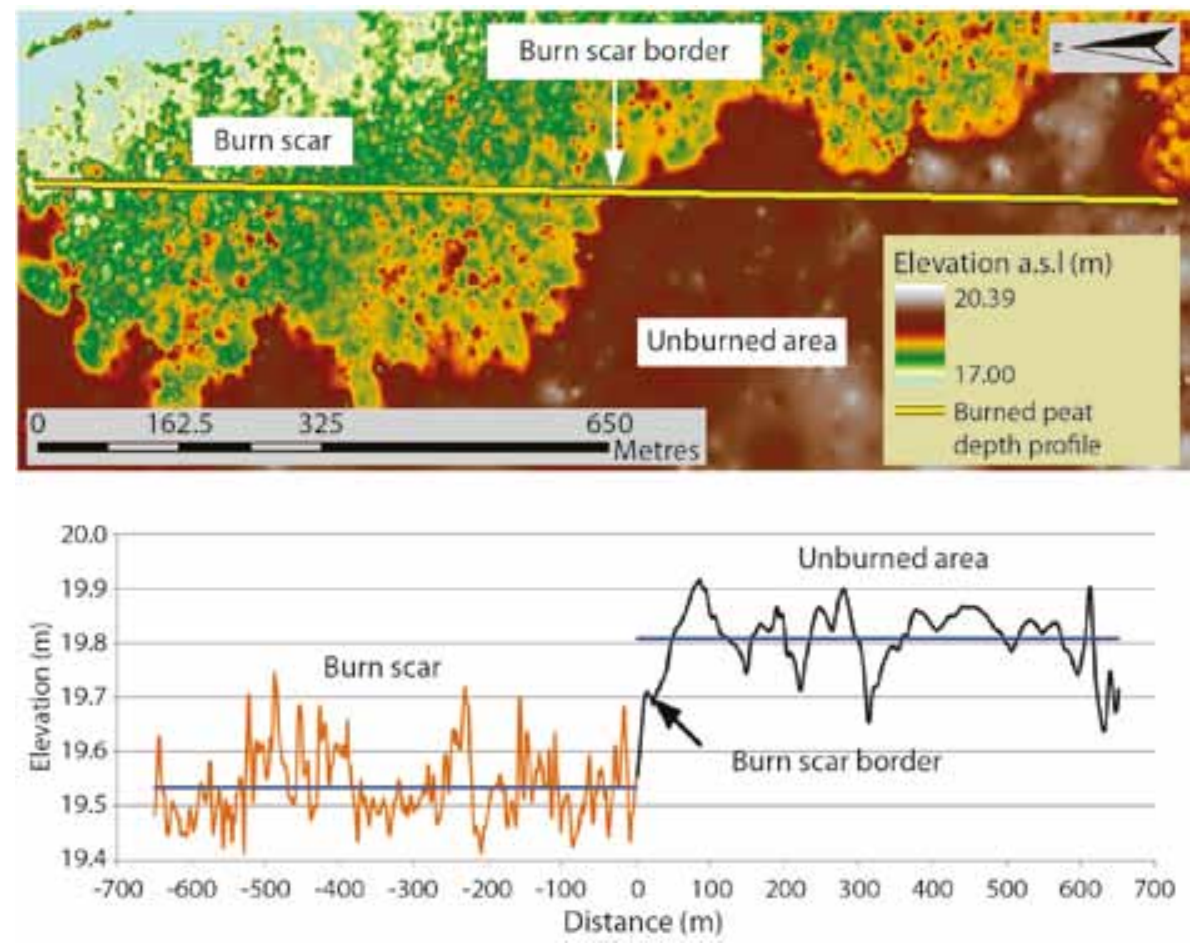

Figure 5.4. Using LIDAR data for the assessment of peat oxidation by fire at different elevation above sea level (a.s.I in meter)

Source: Ballhorn et al. 2009

Table 5.2. Key gaps and recommendations on improving the use of remote sensing for wetland monitoring and analysis

\begin{tabular}{|c|c|}
\hline Variable & Key gaps and recommendations \\
\hline $\begin{array}{l}\text { Land cover (land use) } \\
\text { and change }\end{array}$ & $\begin{array}{l}\text { National monitoring should include degradation and increase in frequency } \\
\text { Clarification of forest definitions and thematic detail/consistency is needed } \\
\text { Long, consistent, time-series processing and analysis (radar?) is needed } \\
\text { Link to spatial planning needs to be established }\end{array}$ \\
\hline $\begin{array}{l}\text { Biomass and carbon } \\
\text { stocks and change } \\
\text { (aboveground) }\end{array}$ & $\begin{array}{l}\text { Research on new remote sensing data available (LIDAR, SAR) } \\
\text { Synergy/interoperability among different sensors needs further work } \\
\text { Field data and calibration and validation are needed; sharing of available data nationally and } \\
\text { from research is important } \\
\text { Sampling schemes, upscaling and standardisation are needed }\end{array}$ \\
\hline $\begin{array}{l}\text { Soil carbon stocks } \\
\text { and change }\end{array}$ & $\begin{array}{l}\text { Only local studies in peatlands (not mangroves) so far - exploration for large area systematic } \\
\text { measurements is needed } \\
\text { Field data for calibration and validation is needed }\end{array}$ \\
\hline Fire & $\begin{array}{l}\text { Data availability for previous studies (synthesis) } \\
\text { High resolution burnt area products }(<10 \mathrm{~m} \text { resolution) } \\
\text { Use of fire radiative energy and develop early warning system } \\
\text { Link to fire fighting teams on the ground is needed }\end{array}$ \\
\hline $\begin{array}{l}\text { Wetland types and } \\
\text { biodiversity }\end{array}$ & $\begin{array}{l}\text { Inconsistencies in existing maps - definitions need to be clarified } \\
\text { National wetlands map for Indonesia, in particular for peatlands, needs to be updated, and } \\
\text { accuracy and detail increased } \\
\text { Definition and approaches to monitoring biodiversity and habitats }\end{array}$ \\
\hline $\begin{array}{l}\text { Wetland hydrological } \\
\text { dynamics }\end{array}$ & $\begin{array}{l}\text { More research is needed on use of Remote Sensing to monitor wetland dynamics, rewetting } \\
\text { Systematic monitoring of coastal zones, loss of land and increased flooding is needed }\end{array}$ \\
\hline Atmospheric carbon & $\begin{array}{l}\text { Use of time series and estimations through GOSAT and Sciamachy } \\
\text { Coarse spatial and vertical resolution }\end{array}$ \\
\hline
\end{tabular}


The gap assessment highlighted the fact that while remote sensing can support different monitoring objectives, some are advanced or operational (such as land-cover change), others are evolving for large area or national assessments, and some are still in the research domain. Thus, knowledge gaps and necessary developments have been identified for different objectives. However, accurate assessments combined with field data analysis are important for all remote sensing studies.

\subsection{Key recommendations for Indonesia}

The following key recommendations are proposed:

Remote sensing is essential for wetland monitoring in Indonesia. Remote sensing approaches are already in use at international, national and local levels. They include monitoring of land cover and changes, biomass and carbon stocks, fires, wetland types, biodiversity, hydrological dynamics, and atmospheric $\mathrm{CO}_{2}$. The continuity of satellite observations is essential, and since Indonesia itself does not have strong satellite monitoring assets, the international community must foster data continuity through national and international programmes.

Free data exchange and transparency is needed, with supportive national policy and a central data repository. The consolidation and synthesis of data and approaches is much needed in Indonesia. Many studies have been conducted involving field and remote sensing data, but availability is limited and, for example, different government institutions still pay for data multiple times (a licensing issue). Thus, a national coordination mechanism and national data infrastructure and data repository (including metadata and quality control) is needed involving governmental, nongovernmental, private sector and research organisations. This should allow for better data exchange between research and governmental organisations and help field researchers and remote sensing experts to work together more effectively.

A national forum is needed to better apply remote sensing technologies for policy making and implementation. The value of remote sensing data products is continually increasing in areas of policy making and implementation. Thus, a forum and communication mechanism on the value, potentials and limitations of remote sensing for policy making should be established, bringing together experts from both science and policy sides.

\section{Capacity development for remote sensing} applications should be continued at governmental and research levels. Remote sensing related capacity development is already being conducted, driven by the national REDD+ readiness process. Such activities should continue and expand to include national higher-education institutions and the monitoring of non-carbon issues with respect to wetlands. 


\title{
6. Revisiting the wetlands chapter in the 2006 IPCC Guidelines
}

\author{
Daniel Murdiyarso, Naomi Swickard, Steve Crooks, Igino Emmer, Kirsfianti Ginoga, Louis Verchot and Xavier Bonneau
}

\subsection{Background}

The Intergovernmental Panel on Climate Change (IPCC) has developed guidelines for parties to the United Nations Framework Convention on Climate Change (UNFCCC) to report their national greenhouse gas emissions (IPCC 2006). Annual reporting of greenhouse gas emissions is mandated for the developed (or Annex 1) countries, whereas non-Annex 1 countries can report less frequently.

In June 2010, the $32^{\text {nd }}$ session of the Subsidiary Body for Scientific and Technical Advice (SBSTA) invited the IPCC to hold an Expert Meeting to explore the need for and ways to clarify methodological issues related to the reporting on harvested wood products, wetlands and nitrous oxide emissions from soils. The meeting, which took place in Geneva in October 2010, recommended the development of additional methodological guidelines on the rewetting and restoration of peatland, emissions from fires, ditches and waterborne carbon, and constructed wetlands for wastewater disposal. Furthermore, the $33^{\text {rd }}$ session of the SBSTA in December 2010, invited the IPCC to produce additional guidance on wetlands focusing on the rewetting and restoration of peatland, with a view to filling gaps in the 2006 IPCC Guidelines for Greenhouse Gas Inventories. The IPCC responded by holding a Scoping Meeting in April 2011 that produced the Terms of Reference and Chapter Outline. This was followed by a timetable to develop the '2013 Supplement to the 2006 IPCC Guidelines for National Greenhouse Gas Inventories: Wetlands'.

When the wetlands chapter in the 2006 IPCC Guidelines was produced (Chapter 7), insufficient scientific information was available for many categories related to greenhouse gas emissions. The methods are only available to estimate emissions from flooded lands, land conversion to wetlands and peat extraction. These guidelines are considered incomplete and information for other categories is lacking.

\subsection{Issues and gaps}

In anticipation of emerging issues in the new climate regime post 2012, it is timely to revisit the gaps in the guidelines for greenhouse gas accounting, particularly with respect to tropical wetland ecosystems. It is very likely that REDD+ in wetlands will be included in the global mechanism.

The definitions related to coastal and freshwater wetlands need to be revisited, while maintaining coherence and compatibility with 2006 Guidelines.

The existing IPCC guidelines on wetlands are summarised in Table 6.1, which clearly illustrates several gaps. The advancement of science in recent years should be taken into account to fill the gaps.

The gaps in the wetlands chapter of the 2006 IPCC Guidelines include the accounting of carbon dioxide $\left(\mathrm{CO}_{2}\right)$ and methane $\left(\mathrm{CH}_{4}\right)$ emissions from 'wetlands remaining wetlands' and from 'lands converted to wetlands'. As Table 6.1 indicates, they are included elsewhere in the other land chapters. Guidance for greenhouse gas accounting when wetlands are converted to other land uses is included in other chapters of Volume 4 (e.g. forest lands, croplands and grasslands), but methods for wetlands that are drained are not provided.

\subsection{Accounting approaches}

The concept for carbon accounting in land uses and following land-use change has remained the same since 1996. This concept, the so called 'stock 
Table 6.1. 2006 IPCC Guidelines for two activities on two wetlands subcategories

\begin{tabular}{lll}
\hline Land-use category/greenhouse gas & Peatlands & Flooded land \\
\hline Wetlands remaining wetlands & & \\
$\mathrm{CO}_{2}$ & Section 7.2.1.1 & No guidance (included elsewhere) \\
$\mathrm{CH}_{4}$ & No guidance (assume negligible) & Appendix 3 \\
$\mathrm{N}_{2} \mathrm{O}$ & Section 7.2.1.2 & No guidance (included elsewhere) \\
\hline
\end{tabular}

\section{Lands converted to wetlands}

$\mathrm{CO}_{2}$

$\mathrm{CH}_{4}$

$\mathrm{N}_{2} \mathrm{O}$

use change (e.g. soils) upstream of the flooded land.

b Methane emissions from peatlands are negligible after drainage, during conversion and peat extraction.

c $\mathrm{N}_{2} \mathrm{O}$ emissions from 'flooded land remaining flooded' are included in the estimates of indirect $\mathrm{N}_{2} \mathrm{O}$ from agricultural or other runoff and wastewater.

Note: The section refers to the section of the 2006 IPCC Guideline

difference' approach, assumes the net carbon flux to equal the changes in carbon stocks over a time interval. Two significant innovations were brought by the 2003 IPCC Good Practice Guidance for Land Use, Land Use Change and Forestry (IPCC 2003). The first was the introduction of accounting methods for six land-use categories (forest lands, croplands, grasslands, wetlands, settlements, and other lands). The second was the definition and introduction of the 'gain-loss' approach as a carbon accounting method. This approach includes all processes that bring about changes in a carbon pool. Gains can be attributed to growth (i.e. biomass increases) and to transfers of carbon from another pool. Losses can be attributed to transfers of carbon from one pool to another or transfers out of the system.

The supplement to the 2006 Guidelines is expected to contain methodologies to calculate emissions in the subcategories of peatland rewetting and restoration, as well as anthropogenic emissions and removals from additional coastal and freshwater wetland types. The guidelines should be consistent with the 2006 IPCC Guidelines for National Greenhouse Gas Inventories and earlier guidelines, as well as best practice guidance.

Scientific knowledge on carbon stocks and fluxes in tropical peatlands (e.g. Couwenberg et al. 2010, Hooijer et al. 2010, Murdiyarso et al. 2010, Hergoualc'h and Verchot 2011), tropical mangroves
(Donato et al. 2011) and temperate tidal marshes (Crooks et al. 2011, Giri et al. 2011) has considerably improved since 2006 and could be further used for updating the guidelines. The methodology to account for non- $\mathrm{CO}_{2}$ gases, including $\mathrm{N}_{2} \mathrm{O}$, must be adequately developed in the supplement. Methodological issues include the choice of method (decision trees and definition of tiers), choice of emission factors, and choice of activity data. General good practice approaches, such as quality and quantity of data, completeness and time series consistency have to be assured in the context of 2006 Guidelines.

\subsubsection{Emission factors}

Emission factors are used to determine emissions or removals of greenhouse gas per unit of area (e.g. tonnes of $\mathrm{CO}_{2}$ or $\mathrm{CO}_{2}$ equivalent per hectare). The emission factors are derived from assessments of the changes in carbon stocks in the various carbon pools (aboveground biomass, belowground biomass, dead wood, litter, soil organic matter). In the case of mangroves and peatlands most of the carbon is belowground. Newly available research results should allow for the development of emission factors for several types of activity in tropical wetlands.

In addition to gaps in $\mathrm{CO}_{2}$ accounting, major gaps exist for non- $\mathrm{CO}_{2}$ greenhouse gases like $\mathrm{N}_{2} \mathrm{O}$ and $\mathrm{CH}_{4}$. This is particularly important when fertiliser is 
used as part of land management practices (Langley and Megonigal 2010), as is often the case in oil palm plantations, and when hydrological changes occur in a high soil organic carbon environment. In addition, wild and man-made fires are likely to change the landscape quite regularly and require emission factors depending on the type and load of fuel. In peatlands, smouldering fires potentially cause significant $\mathrm{CH}_{4}$ emissions and new emission factors need to be developed.

\subsubsection{Activity data}

'Activity data' refers to the spatial extent of categories of either land uses or land-use changes. For practical reasons, activity data are referred to as 'area change data' and expressed in hectares. In the case of wetlands those land use and land-use change categories should not only include the area of vegetation cover and cover change but also water regimes such as the presence of drainage, which affects the dynamics of biogeochemical cycles and belowground carbon stocks. Land-use change in wetlands is often associated with changes in hydrology. Human-induced drainage for agriculture and rewetting are part of management practices or activities. The area affected should be recorded to produce estimates for accounting purposes. Spatially explicit monitoring, using remote sensing techniques and mapping, can also be employed for better determination of activity data (e.g. Fatoyinbo et al. 2008).

Sedimentation in coastal wetlands, one of the least studied factors affecting their greenhouse gas emissions, may affect the dynamics of vegetation expansion or disappearance. Records on such phenomenon are lacking and need to be improved (Syvitski et al. 2009).

\subsection{Recommendations}

\subsubsection{Wetlands subcategories}

We suggest that wetlands remain one of the land-use categories like forest lands, croplands, grasslands, settlements and other lands. Three subcategories, comprising coastal wetlands, peatlands and other freshwater wetlands, could be adopted and activities within each subcategory defined. These activities could be of significance for individual subcategories, including vegetation clearance (followed by biomass burning, filling, drainage, conversions to aquaculture and agriculture), changes in hydrology, application of fertilisers and wastewater, and restoration.

Indeed, wetlands restoration and management, for mitigating climate change, requires specific greenhouse gas accounting methods, which are currently not available in the wetlands chapter. Carbon accounting methods unique to wetland activities should be developed and used to supplement accounting in other land-use categories, in the same way as non- $\mathrm{CO}_{2}$ greenhouse gas accounting methods.

The activities listed in Table 6.2 indicate the need for adequate emissions factors and methods to derive them. To meet the adequacy of method that will determine the level of tier, efforts need to be prioritised based on the importance of the activities in releasing greenhouse gases into the atmosphere or removing them from it.

Information on soil carbon and belowground biomass is becoming more easily accessible. Information on fire emissions, however, is lacking in many cases, particularly in terms of accounting methods. As fire is an important land management tool in many developing countries, relevant accounting methods need to be decided sooner rather than later.

\subsubsection{Alignment of definitions}

Wetlands share common characteristics with forests and grasslands with regard to aboveground biomass. Mangroves can be considered a subset of forests and marshes a subset of grasslands. What distinguishes wetlands from existing grassland and forest categories is the role of wet conditions in the soil in carbon storage, emissions of $\mathrm{CH}_{4}$ in freshwater conditions, enhanced emissions of $\mathrm{N}_{2} \mathrm{O}$ when loaded with nitrogen precursors, and emissions of $\mathrm{CO}_{2}$ but reduced emissions of other greenhouse gases when the water table is lowered.

An additional characteristic of wetlands is their capacity to continuously accumulate carbon through root biomass production and soil storage, if water levels are raised at a rate that does not threaten vegetation presence or exceed soil building capacity. As a result, wetlands in isolated drainage areas, subsiding basins and coastal areas may be prolonged 
Table 6.2. Activities in wetlands and adequacy for emissions factors and quantification methods

\begin{tabular}{lccc}
\hline Activity & Emission factor adequacy & Method adequacy & Priority \\
\hline Clear and drain & No & Yes & 4 \\
Clear and aquaculture $^{\mathrm{a}}$ & Yes & No & 3 \\
Clear, drain and agriculture $^{\text {Clear and paludiculture }}{ }^{\mathrm{b}}$ & Yes & No & 3 \\
Wastewater treatment $_{\text {Change in hydrology }}$ & Yes & No & 3 \\
Use of fires (smouldering) & No & Yes & 2 \\
Use of fertiliser & Yes & No & 4 \\
(induced decomposition) & Yes & No & 1 \\
\hline
\end{tabular}

a Brackish water ponds are used to cultivate shrimps or fish in coastal areas as part of traditional aquaculture. Mangrove trees are sometimes grown within the dykes or inside the fish ponds. Aquaculture is usually implemented on areas converted from mangroves.

b Cultivation of biomass on wet and rewetted peatlands. This is considered an innovative alternative to conventional drainagebased peatland agriculture and silviculture (Wichtmann et al. 2010). No application has been observed in the tropics.

sinks for carbon over periods of time that far exceed upland terrestrial grasslands and forests, in which the soil carbon pool reaches a saturated state as organic production and decay establish a dynamic equilibrium.

Like forests and grasslands, the full consideration of the soil carbon pool is poorly represented. The soil pool can be subdivided into mineral and organic subsets, and while the emissions from mineral soils are relatively insensitive to land-use change, the emissions from organic soils are highly sensitive and potentially much larger and more prolonged.

We therefore recommend that a separate wetlands subcategory be recognised reflecting 1) differentiation between mineral and organic soils, and 2) differentiation between saline (non$\mathrm{CH}_{4}$ producing conditions) and freshwater $\left(\mathrm{CH}_{4}\right.$ producing conditions).

Based upon the key criteria above we recommend focusing on the following major wetland classes:

\section{Coastal wetlands}

These include mangroves, tidal marshes (fresh and saline) and sea grass meadows. Drainage of coastal wetlands results in emissions of carbon accumulated over hundreds to thousands of years. The soil, rather than living biomass, is commonly the major carbon pool; that may be subdivided into mineral and organic subsets. The following release of greenhouse gases may occur:

- carbon dioxide, if wetlands are prevented from landward migration;

- methane, at salinities 50\% that of seawater;

- nitrousoxide, which is not typically a product of wetlands unless subject to terrestrial nitrogen loading (common in many coastal areas because of upstream pollution).

\section{Peatlands}

Peat accumulates in wetlands when the annual generation of dead organic matter exceeds the amount that decays. The pattern of peat deposit development varies with climate and hydrology. Accumulations of carbon continue in regions where water table elevation is rising at rates that do not preclude vegetation growth and soil building.

In the IPCC Guidelines, peatlands include all lands cleared and drained for production of peat for energy, horticulture and other uses. The emissions of greenhouse gases from peatlands continue throughout the entire cycle of peat production, which include 1) release of carbon accumulated over hundreds to thousands of years when soils are drained, and 2) release of methane under undisturbed baseline conditions. 


\section{Other freshwater wetlands}

Other freshwater wetlands may occur on mineral soils. They have soil carbon storage that is enhanced by wet conditions relative to non-wetland soils. They will 1) release carbon when soils are drained but decay to zero within a relatively short time frame, and 2) release methane under undisturbed natural conditions (though this may be seasonally variable depending upon flooding regimes).

It is recognised that tropical wetlands occur along complex environmental gradients and within human modified landscapes, resulting in a great diversity of physical, biological and functional characteristics. As such, it has been a continuous challenge to adequately define and generalise wetlands as a whole, to provide specific guidelines and provisions for the measurement of greenhouse gas emissions. This challenge has been particularly acute for peatlands, which are often described qualitatively and have various technical definitions under major soil classification systems.

Other gaps identified in the 2006 Guidelines are rewetting and restoration of wetlands, aquaculture ponds, irrigated land (except rice), salt exploitation sites, constructed wastewater treatment areas, canals and drainage channels, and ditches. Most of these subcategories will be addressed in the 2013 Supplement to the 2006 Guidelines. 


\title{
7. Human dimensions and the roles of tropical wetlands in adaptation to climate change
}

\author{
Emilia Pramova, Terry Hills, Enny Widyati, Heru Santoso, Joko Purbopuspito, Lailan Syaufina, Niken Sakuntaladewi, \\ Norman C. Duke, Sukristijono Sukardjo, Andrio Adiwibowo and Cut Rizlani Kholibrina
}

\subsection{Background}

The ecosystem services provided by wetlands are often unrecognised or remain undervalued in landuse practices, leading to their conversion and overexploitation. Both tidal and freshwater wetlands are vulnerable to anthropogenic activity, as well as climatic pressures such as temperature shifts, sealevel rise, droughts, floods and changes to seasonality (MEA 2005). These pressures are predicted to become more variable and/or intense with climate change, potentially leading to severe cumulative effects. In Indonesia, communities that are heavily dependent on these wetlands are already struggling to maintain their livelihoods in an environment of increasing climatic variability and competition for resources; and in doing so, may be adopting land-use and fishery practices that will increase their future vulnerability to climate change. Additionally, climate pressures may combine in ways that amplify the overall impacts. Coastal communities for example will be facing sea-level rise, coastal ecosystem shifts and alterations in freshwater availability, all at once.

Adaptation to climate change is defined as the adjustment of natural or human systems in response to actual or expected climatic stimuli or their effects, which moderates harm or exploits beneficial opportunities (IPCC 2001). Failure to adapt to climate change will increase the vulnerability of both wetlands and communities, and incur the expense of later adaptation.

Vulnerability is a central concept to adaptation and is defined as the degree to which a system is susceptible to, or unable to cope with, adverse effects of climate change, including climate variability and extremes (IPCC 2001). It is a function of the character, magnitude, and rate of climate variation to which a system is exposed, its sensitivity, and its adaptive capacity (Figure 7.1). Sensitivity is characterised as the degree to which a system is affected, either adversely or beneficially, by climate variability or change; whereas, adaptive capacity is the ability of a system to adjust to this change, moderate potential damages, take advantage of opportunities, and/or cope with the consequences. Reducing the vulnerability of wetland ecosystems to climate change is critical, but wetlands can also help reduce the vulnerability of people to climate variability and change, through the range of ecosystem services that they provide, such as storm and tidal flood protection (Badola and Hussain 2005, Das and Vincent 2009) and provision of livelihood and food security through primary and secondary productivity of these systems (Tri et al. 1998, Walton et al. 2006, Sukardjo 2010). Conversely, degraded wetland ecosystems can increase the vulnerability of communities, as losses in ecosystem services impact human well-being negatively and limit social adaptive capacity (Kelly and Adger 2000).

The links between wetland ecosystem services and human well-being and vulnerability are complex,

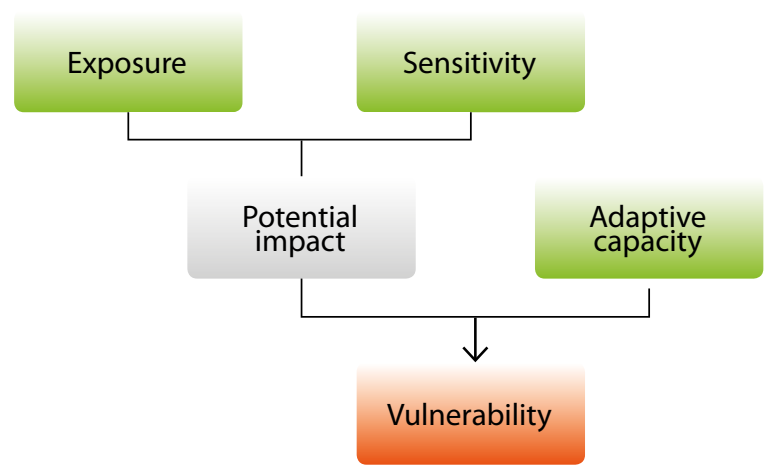

Figure 7.1. Vulnerability as a function of exposure, sensitivity and adaptive capacity 
nonlinear, and can vary on temporal and spatial scales. However, only a limited number of scientific studies are available that quantify the vulnerability of wetland ecosystems and communities and the value of wetland ecosystem services for adaptation in specific contexts and locations. Kelly and Adger (2000) illustrate the relationship between access to secure flows of mangrove ecosystem services and societal vulnerability in Vietnam, and Adiwibowo (2011) explores the same relationship in Indonesia. Sukardjo (2010) assesses the value of mangrove goods and services in Indonesia, Walton et al. (2005) in the Philippines and Adger et al. (1997) in Vietnam. The protective role of mangroves against storms and cyclones in India is evaluated by Badola and Hussain (2005) and Das and Vincent (2009). Sukardjo (2011) examines the vulnerability of mangrove ecosystems in Indonesia and Duke (2011) in Australia. Costanza et al. 2008 assess the value of coastal wetlands for hurricane protection in the USA. Finally, the role of salt marshes and inter-tidal habitats for buffering sea-level rise is examined by Singh et al. (2007) in Canada, and Turner et al. (2006) in the UK.

These studies make a significant contribution to our understanding; however, we lack empirical evidence, especially on the regulation of ecosystem services, and incremental changes such as sea-level rise. We have few integrated vulnerability assessments of both natural and social systems, such as that by Santoso et al. (2011), and insufficient evaluations from different geographical locations and conditions. Similar studies on peatlands are almost nonexistent. There is also a critical gap in studies accounting for ecosystem benefits that occur in locations distant to the ecosystems in consideration, such as the benefits that offshore fisheries derive from mangroves.

Furthermore, very little is known about the thresholds within which these wetland ecosystems will be able to successfully respond to changes, as well as the potential feedback responses by society. Wetland ecosystems can progressively transform into states that are no longer socially acceptable or supportive of human needs; we need to understand when, where and how such transformations may arise. For example, some evidence suggests that reductions in direct and catchment rainfall may contribute to the conversion of one type of tidal wetland into another, such as mangrove systems into salt marshes (Duke 2011). More research is needed in this area, as such information is critical to planning long-term adaptation responses.

As decision makers face difficulties in setting priorities, with so many uncertainties and limited resources, the science related to wetlands and adaptation needs to be advanced. Integration of existing knowledge from different scientific disciplines will be a useful exercise for adaptation planning, to help illuminate the socio-ecological costs and benefits of different adaptation strategies and development pathways.

\subsection{Socio-ecological systems and the knowledge needed for adaptation}

Adaptation is an overarching discipline dealing with multiple dimensions in complex socio-ecological systems. In this sense, the knowledge needed to foster adaptation also spans across disciplines, and one of the main related challenges is the integration of this knowledge. The Workshop on Tropical Wetland Ecosystems of Indonesia highlighted a number of studies and science needs related to land-use change, ecosystem dynamics, biodiversity, deforestation and/ or carbon stocks and fluxes in peatland and mangrove ecosystems. All of these sources of information can be useful for adaptation but a lot more needs to be done in order to effectively respond to climate challenges. Wetlands are, and will be, affected by diverse climatic drivers. Mangroves, for example, are not only impacted by sea-level rise but are also highly sensitive to fluctuations in temperature and rainfall. (Figure 7.2). Peatlands are very sensitive to climate due to the direct impact of climate variability on peat hydrology, physical processes, peat accumulation and carbon storage, biotic functions and morphology (Charman 2002). However, different species respond in different ways to different pressures and combinations of pressures. It is thus important to consider the diversity of individual species responses to a broad suite of interacting climate variables, biotic factors and anthropogenic stressors.

Biological inventories of wetland species need to be further advanced to reflect ecosystem distribution, state and functions within specific ecological assemblages and climatic zones and locations. It is essential to monitor different ecological assemblages 


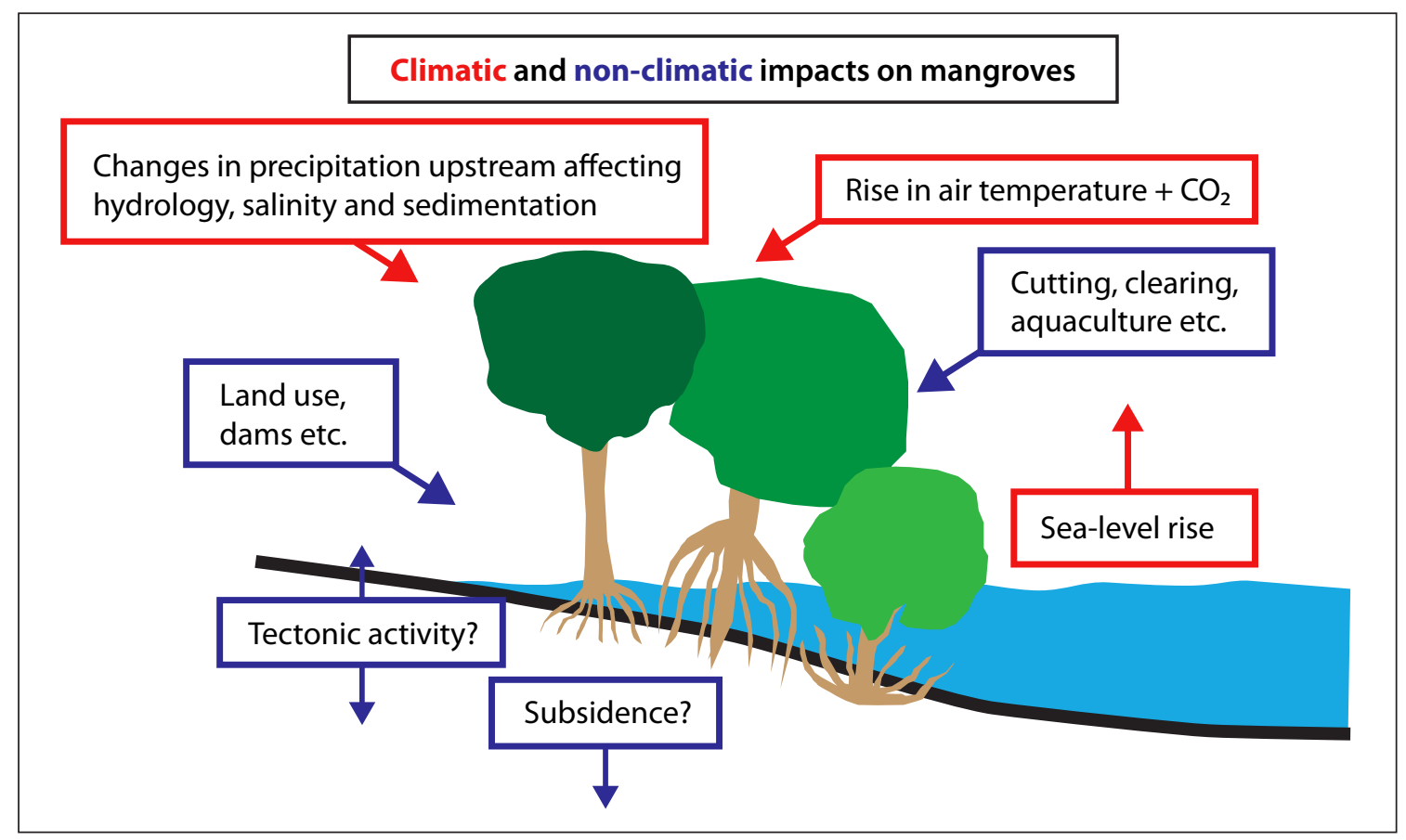

Figure 7.2. Climatic and non-climatic impacts on mangroves

Source: Redrawn from Ellison et al. 2010

in order to effectively assess processes of change. As discussed in Chapter 5, remote sensing can be very effective in monitoring wetland status, dynamics and change; however, much work remains in defining approaches to monitoring biodiversity and in integrating field data analysis. Ecological observations in real time are an important component of integrated climate change-biodiversity assessments, as many species are altering their ranges and phenological responses in ways consistent with relatively small climatic changes (Dawson et al. 2011).

Adaptation is needed for wetlands to maintain their function. For the successful implementation of any adaptation activities, it is critical that current threats to wetlands are reduced (e.g. deforestation and degradation). Along with the various impacts of climate change, anthropogenic pressures need to be considered in adaptation planning for wetland systems, particularly given the rate of their degradation.

Chapter 3 illustrates the dominant land uses and land-use change patterns in wetland ecosystems. It also describes typical conversion patterns for peatlands, although it is difficult to make similar generalisations about mangroves. In addition to understanding and monitoring the impacts themselves, it is imperative to research the underlying causes of human behaviours that affect wetland ecosystems. Communities with different levels of resource dependency and access, perceptions of ecosystem values and problems, livelihood alternatives and tenure rights, interact with wetland ecosystems in different ways (Iftekhar and Takama 2008). We need to understand why certain coastal wetland communities choose to protect, restore or use mangroves sustainably (e.g. for provisioning services such as crabs, honey, fodder and tannin, or for protection against storms) while other communities engage in exploitative or destructive uses (e.g. clearing for fish ponds, agriculture, salt production, settlements). Studies from the Philippines, for example, demonstrate that community acknowledgment of the value of mangroves for coastal protection, livelihoods and food security, and the awarding of community land tenure rights, contributed immensely to the success of a mangrove restoration project and the subsequent protection of the resource (Walton et al. 2006). External factors, such as market forces and government policies, should also be examined (Kelly and Adger 2000). 
Researchers need to examine how environmental governance problems and processes of change are explained by communities, institutions and other local stakeholders. It is important to understand how drivers of change are perceived within a system, what they mean and what can be done to address them (Mustelin et al. 2010). As mentioned in Chapter 2, a clearer understanding of the long-term consequences of wetland degradation and conversion, and the implementation of related awareness programmes and institutional linkages, could reduce differences in perceptions among stakeholders and actors.

Wetland and coastal communities are also highly vulnerable to climate change, and the protection or restoration of ecosystem services can help them adapt to both current climate hazards and future climate change. Mangroves, for example, reduce the vulnerability of coastal settlements to both extreme weather events and sea-level rise, and they also contribute to livelihoods and food security. Appropriate management activities can balance the need for immediate benefits (e.g. livelihoods) with the preparation for longer-term climate change impacts. This balance is critical for the sustainability of adaptation actions.

According to The Economics of Ecosystems and Biodiversity (TEEB) initiative, maintaining nature's capacity to buffer the impacts of climate change is often less costly than having to replace lost ecosystem functions by heavy infrastructure or technology. In many cases, an ecosystem investment can be justified solely on the basis of one valuable service, but it becomes even more attractive when the whole range of services provided by this particular ecosystem is taken into consideration (TEEB 2009). For instance, planting and protecting nearly 12000 hectares of mangroves in Vietnam required an investment of US $\$ 1.1$ million, but this restoration activity now saves US\$7.3 million annually in dyke maintenance expenditures. When the additional benefits of the investment are considered, namely the protection of land, property and human life from typhoons and storms and the provision of valuable goods such as shrimp and crabs, it becomes even more desirable from an economic perspective.

Similar studies in Vietnam have highlighted the economic efficiency of mangrove restoration for both climate change adaptation and the enhancement of food security and livelihoods (Tri et al. 1998), and studies in India have demonstrated the role of mangroves in disaster risk reduction (Badola and Hussain 2005, Das and Vincent 2009). However, few such studies are available in other countries and contexts, and especially as related to peatlands. This is particularly alarming for peatlands, which have become new frontiers for unsustainable agricultural expansion (Murdiyarso et al. 2010).

The ecosystem services provided by wetlands in different regions and landscape types need to be evaluated in a comprehensive manner. Chapter 3 indicates various ecosystem services of tropical wetlands that can be directly quantified. Valuations of wetland ecosystems can be expressed in economic and/or social and ecological terms. The recognition and valuation of ecosystem services also facilitates the identification of relevant stakeholders by linking a specific ecosystem (supply side) to the stakeholders representing the demand side (Slootweg and van Beukering 2008). In early planning stages, the recognition of ecosystem services and identification of stakeholders can provide a better understanding and guide future vulnerability assessments. It can also provide important clues on the potential winners and losers of specific changes in socio-ecological systems.

In conclusion, strategies are needed to ensure the role of wetland ecosystems in social adaptation, and such strategies should be supported by a diverse pool of knowledge sources. The role of different jurisdictions and government structures, both in terms of producing and disseminating knowledge and in catalysing adaptation action, also needs to be explored. Initial questions to be answered are who is responsible for what, and how is this responsibility practiced? What are the different levels of institutional capacity to undertake adaptation actions and where do we need to build it further? Are there any channels for cross-institutional cooperation and what incentives could operationalise them?

Vulnerability assessments that are specific to wetlands and wetland-dependent communities are much needed. This is the key to both guiding action based on existing knowledge and establishing a strategy for filling critical data gaps, where such gaps are preventing effective adaptation planning. 


\subsection{Approaches to building and communicating knowledge}

The elaboration of integrated vulnerability assessments is one action-oriented pathway for integrating scientific knowledge from different disciplines, producing new and relevant knowledge, building awareness and capacity, and informing policy.

Conducting vulnerability assessments is an effective way of identifying specific drivers of change in different wetland socio-ecological systems. Such assessments can improve our understanding of system dynamics, raise awareness regarding the causes of vulnerability, and inform and prioritise planning options. An appropriate framework, such as the one developed to assess coupled human-environment systems in the Tropical Forests and Climate Change Adaptation (TroFCCA) project, needs to be applied (Figure 7.3). This conceptual framework emphasises the role of ecosystems for society, linking the ecological and social factors of vulnerability.

As Locatelli et al. (2008) describe, the first set of criteria (Figure 7.3) deals with the vulnerability of ecosystem services to climate change or variability and other threats such as land-use change. It encompasses criteria related to exposure and sensitivity to threats, and ecosystem adaptive capacity as a function of current degradation or other pressures. During the elaboration of the vulnerability assessments, an effort needs to be made in identifying the thresholds within which wetland ecosystems change. Mangrove peat accumulation for example, needs to exceed the rate of sea-level rise for the mangrove community to successfully 'migrate' landward. It is critical to develop the appropriate indicators for the examination of species limits under different ecological conditions, as tipping points ${ }^{2}$ can

2 The term 'tipping point' refers to a situation in which forces that create stability are overcome by forces that create instability, leading the system into disequilibrium. Once an ecological system tips into disequilibrium, it can potentially reach a new, but quite different, dynamic equilibrium (Cairns 2004). A change at the tipping point sets in motion mutually reinforcing feedback loops that propel the system on a completely new course, which can lever far-reaching change in the system (Marten 2005). How easily a system reaches tipping points relates closely to the concept of resilience. Ecosystem resilience is the capacity of an ecosystem to tolerate disturbance without collapsing into a qualitatively different state that is controlled by a different set of processes. Reduced resilience, which is most frequently induced by anthropogenic pressures, increases the vulnerability of a system to smaller disturbances that it could previously cope with. make a big difference for planning and prioritising adaptation (examples of indicators presented in Table 7.1).Modelling approaches and input from published data can also be very useful for this purpose, as discussed in Chapter 4.

The second set of criteria (Figure 7.3) deals with the human system or the society and its vulnerability to the loss of ecosystem services and other threats (e.g. climate change, economic or political changes). The sensitivity of the system (e.g. dependence on mangrove products) and its adaptive capacity (e.g. availability of substitutes for lost services) can be used as criteria. External drivers of change, such as macroeconomic policies or energy prices, must also be taken into account in this set of criteria.

The third set of criteria (Figure 7.3) considers the adaptive capacity of the system as a whole. It refers to the capacity of the human systems to reduce the loss of ecosystem services. Criteria can refer to the capacity for removing practices that increase pressures on ecosystems and the capacity to implement adaptation of wetlands.

In relation to the second and third sets of criteria, Kelly and Adger (2000) argue that the inherently political nature of issues such as property rights should not be ignored, as they affect levels of vulnerability. By analysing the vulnerability of mangrove socio-ecological systems in Vietnam, the authors show that the extent to which individuals are entitled to make use of resources determines the ability to cope with or adapt to stress, with strong links between inequality, lack of diversification of income sources and poverty. Following Sanderson and Turner (1994), they conclude that vulnerability assessments should encompass an analysis of the political economy and structure of institutions of a given socio-ecological system, the constraints on institutional adaptation and evolution, and the constraints that institutions impose on individuals.

National vulnerability mapping exercises can be useful for identifying hotspots where urgent action is required. National assessments, however, can missout on vulnerable systems at the very local level, depending on the parameters used and the quality of the data. An integrated approach is thus needed, where local and landscape-level assessments feed into a national knowledge base or 'vulnerability layer'. 


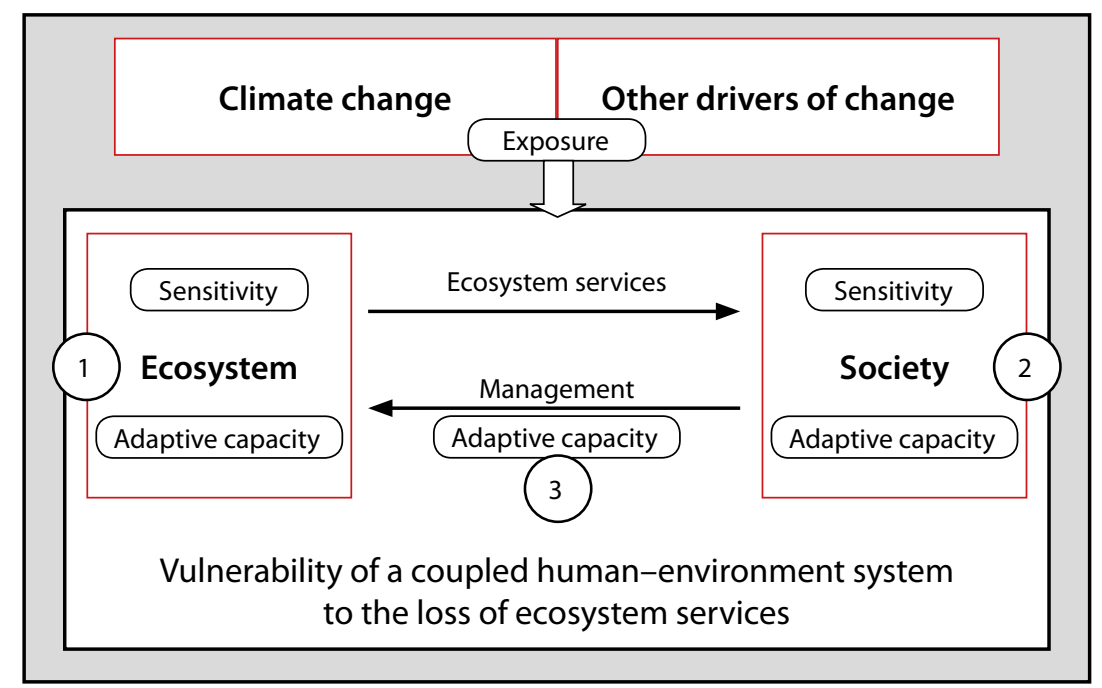

Figure 7.3. Vulnerability assessment framework of coupled human-environment systems

Source: Locatelli et al. 2008

Landscape-level approaches can be quite useful, for the identification of cumulative and indirect drivers of ecosystem and social vulnerability, as well as for effective and sustainable cross-sectoral adaptation. Such approaches could also aid planners in making sure that adaptation and other benefits derived from ecosystems are channelled effectively to the stakeholders concerned, since ecosystem benefits and management costs can occur in different locations and affect different sectors and divisions of society. Landscape-level assessments can also be used to inform integrated wetland management strategies at the appropriate spatial scales, an issue discussed in Chapter 3, where it is highlighted that management activities upstream can have a large impact on forests downstream.

As Indonesia and other tropical countries will soon proceed with national adaptation action plans, it is imperative to make sure that wetlands are considered by conveying the appropriate knowledge to decision makers in a practical manner. Thus far, wetlands haven't been taken into account in broader adaptation strategies.

A good start, for synthesising knowledge needs and testing the approaches described in Indonesia, for example, would be to proceed with integrated vulnerability assessments and then adaptation strategies at $8-10$ selected locations in the country. The mix of selected sites should be representative of different wetland types (including coastal and inland peatlands, tidal wetlands and mangroves) and socioeconomic conditions of wetland communities. Vulnerabilities, and subsequently appropriate adaptation actions, can vary significantly across different spatial and temporal scales and social configurations.

Effective and consistent monitoring with robust assessment methods will be essential for tracking tipping points as well as variations in vulnerability levels over time, as conditions change. The engagement of local institutions and communities in the monitoring process will be vital.

A participative process will not only enhance science and knowledge but also the awareness and capacity of the people that live with the ecosystems. Participatory action research networks involving scientists, communities, nongovernment practitioners and local government can inform action in a continuous manner, where activity results and feedback loops are constantly monitored and evaluated, and the relevant information is used to readjust strategies under uncertainty. They can act as knowledge generating mechanisms for adaptive management, but also as the foundation for a broader science-policy dialogue.

Scenario planning can be a promising tool to expand on, but also to inform vulnerability assessments. Scenario development is focused on creating 
alternative, yet plausible, future states by asking 'what if' questions, examining possible challenges and response actions under conditions of uncertainty.

In this sense, scenarios can be used for exploring future vulnerability, ecological tipping points and the costs and benefits of adaptation action and inaction under different climatic and socioeconomic conditions. The use of scenarios to explore socioecological dynamics of alternative futures is not new, although it only recently captured broad attention with the Millennium Ecosystem Assessment.

Scenarios however have been greatly underutilised for adaptation planning, and especially as related to wetlands and wetland-dependent communities.

Nicholls et al. (2008) make several suggestions for the development of scenarios related to climate change and coastal vulnerability assessments. Most importantly, they argue for the consideration of nonclimatic environmental change or socioeconomic change by down scaling the story lines of the Special Report on Emission Scenarios (SRES) of the IPCC. This can provide a basis on which to interpret the possible future state of coastal zones, including a range of societal attitudes (Table 7.1). The different narratives are attached to likely greenhouse gas emissions that can be used to drive climate models and construct scenarios of climate change, whose potential impacts and adaptation needs can be analysed using the 'world' that produced them. The authors also note that impacts in coastal areas will depend on the amount and success of adaptation to climate and other changes, which remains a complex issue that is poorly understood. They call for empirical approaches that collect more data on how and why people adapt.

We propose that scenario exercises are undertaken for various wetland ecosystem types and the costs and benefits explored (both socioeconomic and ecological) of various adaptation and development trajectories under different alternative futures and emission levels from SRES. In relation to wetlands and coastal zones, possible adaptation alternatives to be explored can include:

- business as usual development (no adaptation, where ecosystem conversion continues);

- conservation and rehabilitation (focus on ecosystem services);
- raising and reinforcing coastal infrastructure (engineering solution);

- planned retreat;

- selective conservation and realignment of current defences etc.

A critical component of this exercise would be the definition of appropriate socio-ecological indicator sets, which can be done in collaboration with ecosystem modellers, experts studying land-use and land-cover change etc. Indicator values could be derived by hypothesising variations around extrapolated historical trends. Table 7.1 illustrates example indicators.

Scenarios could provide insights into potential coping and adaptation strategies that societies might embark on under different conditions, which can be assessed for their sustainability against the various indicators. Some societal strategies might amplify change, while others might dampen that change. Participatory approaches in scenario planning can be employed to explore community responses to hypothetical climatic and ecosystem shifts. Finally, scenario exercises can reveal key trade-offs in ecosystem services in space and time and are a powerful tool for communication and engagement of stakeholders.

\subsection{Recommendations}

In a time of limited resources and competing priorities, convincing decision makers to secure funding for vulnerability research and adaptation planning can be a challenge. Furthermore, competing jurisdictions might strive for different agendas, making the multi-scale and multi-disciplinary task of adaptation all the more challenging. If specific problems are not perceived as existing (e.g. ecosystem degradation, climate hazard threats, frequent occurrence of extreme events) by both communities and decision makers, it is quite difficult to communicate the value of adaptation and ecosystem service protection. Even if specific problems are perceived, in many cases the low level of awareness regarding the relationship between ecosystem services and climate change, and/or the low level of capacity in climate change planning, can be significant barriers to action. Furthermore, insecure resource rights and tenure can act as the decisive factor in 
Table 7.1. Example indicators for scenario analysis

\begin{tabular}{|c|c|c|c|c|}
\hline $\begin{array}{l}\text { Mangroves } \\
\text { (ecological) }\end{array}$ & $\begin{array}{l}\text { Peatlands } \\
\text { (ecological) }\end{array}$ & Social dimensions & Climate indicators & SRES narratives ${ }^{a}$ \\
\hline Biodiversity & Biodiversity & Livelihoods & Sea-level rise & $\begin{array}{l}\text { A1 (World market) } \\
\text { - increasing globalisation, }\end{array}$ \\
\hline Biomass & Biomass & Food security & Precipitation & $\begin{array}{l}\text { - rapid global economic } \\
\text { growth, }\end{array}$ \\
\hline Canopy & Regeneration & Health & Drought & - materialist/consumerist, \\
\hline Regeneration & Subsidence & Personal safety & $\begin{array}{l}\text { Temperature } \\
\text { fluctuation }\end{array}$ & $\begin{array}{l}\text { - rapid uniform technological } \\
\text { innovation }\end{array}$ \\
\hline Salinity & Carbon storage & Tenure & & A2 (National enterprise) \\
\hline Water quality & Peat depth & Social relations & $\begin{array}{l}\text { (hurricanes, } \\
\text { cyclones etc.) }\end{array}$ & $\begin{array}{l}\text { - heterogeneous world, } \\
\text { - rapid regional economic }\end{array}$ \\
\hline Sedimentation & Flammability & Culture & & $\begin{array}{l}\text { growth, } \\
\text { - materialist/consumerist, }\end{array}$ \\
\hline Conversion & Water levels & Markets & & $\begin{array}{l}\text { - diverse technological } \\
\text { innovation }\end{array}$ \\
\hline \multirow[t]{4}{*}{$\begin{array}{l}\text { *Ecosystem tipping } \\
\text { points }\end{array}$} & Conversion & & & B1. (Global sustainability) \\
\hline & Soil acidity & & & $\begin{array}{l}\text { - environmental priority, } \\
\text { - global cooperation, }\end{array}$ \\
\hline & $\begin{array}{l}{ }^{*} \text { Ecosystem tipping } \\
\text { points }\end{array}$ & & & $\begin{array}{l}\text { clean and efficient } \\
\text { technologies }\end{array}$ \\
\hline & & & & $\begin{array}{l}\text { B2 (Local stewardship) } \\
\text { - environmental priority, } \\
\text { - heterogeneous world/local } \\
\text { emphasis, } \\
\text { - clean and efficient } \\
\text { technologies }\end{array}$ \\
\hline
\end{tabular}

SRES = Special Report on Emission Scenarios

a After Nicholls et al. 2008

whether communities and local institutions choose to adapt sustainably or proceed with short-term exploitative coping strategies.

A first step for overcoming the barriers is to create an enabling environment for effective science-policy dialogue. In the Indonesian context, this could be done by setting up a climate change advisory body for wetlands, and proceeding with participatory action research. A second step would be to identify sites for the vulnerability assessments, whose goal would be to inform adaptation policy and build on the national 'vulnerability layer'. Cross-sectoral workshops could be conducted in the selected landscapes with all stakeholders involved, to identify important indicators and system dynamics. An essential part of the whole process would be the creation of knowledge networks, partnerships with local institutions and nongovernmental organisations, and capacity building and empowerment of decision makers and wetland-dependent communities.

In essence, what we propose is the achievement of what Füssel and Klein (2006) describe as 'adaptation 
policy assessments'. These assessments aim to contribute to policy making by recommending specific adaptation measures, and are characterised by the intensive involvement of stakeholders, by a strong emphasis on the vulnerability of a population to climate variability, by the formulation and evaluation of response strategies that are robust against uncertain future developments, and by the integration of adaptation measures with existing policies. Facilitation activities that enhance adaptive capacity, such as scientific research, data collection, awareness raising, capacity building, and the establishment of institutions, information networks and legal frameworks for action are a central component.
A strong focus is needed on the elaboration of integrated vulnerability assessments of wetland socioecological systems, which take into account diverse drivers of change and constraints to adaptation. In parallel, the different values of wetland ecosystem services for adaptation and general human wellbeing need to be assessed and integrated into land-use planning.

Wetland dependent communities can be critical partners in change monitoring, knowledge building and conservation and sustainable management. Their participation in adaptive collaborative management schemes needs to be encouraged through the right incentives. 


\section{The way forward}

Emilia Pramova and Daniel Murdiyarso

\subsection{The approach}

The large carbon stocks found in tropical wetland ecosystems are the result of net positive carbon balance accumulated over thousands of years. The carbon pools of tropical peatland and mangrove ecosystems can be over twice the amount found in upland tropical and temperate forests. What gives particular importance to these ecosystems is the fact that a great proportion of the carbon stocks are stored in belowground organic-rich soils, which can release significant amounts of greenhouse gases if disturbed.

Studies have demonstrated that even small anthropogenic and/or environmental influences can cause considerable impacts and feedback loops in tropical wetland ecosystems. For example, any landuse on peatland ecosystems that involves drainage, such as agriculture, results in oxidation of organic matter and net increases of greenhouse gas emissions over time, even at optimal drainage depth. Peat subsidence continues for as long as peatlands are used for agriculture, not only contributing to greenhouse gas emissions but also making it impossible to sustain the land use for long periods of time. When mangroves are converted for aquaculture, substantial carbon emissions are released through the excavation of mangrove soils. Similarly to peatland ecosystems, the carbon oxidises after disturbance and continues to do so for decades following the conversion. But even when soils are not excavated, and mangroves are exploited for timber and forestry, soil erosion can occur leading to carbon releases into the water column, and ultimately into the atmosphere.

Little is known, however, about exports of carbon in ground water and the links between greenhouse gas fluxes and functional factors, such as mean water table depths, surface soil temperature and fertilisation. Degraded peatlands are also highly susceptible to fire, although not much is known about the distribution of fuel loads and potential cumulative releases of combinations of greenhouse gases $\left(\mathrm{CO}_{2}, \mathrm{CH}_{4}\right.$ and $\left.\mathrm{N}_{2} \mathrm{O}\right)$. Large carbon losses occur from aboveground biomass harvest and combustion from fire, heterotrophic oxidation of drained peat, and export as dissolved organic carbon and particulate organic carbon, although great knowledge gaps exists regarding the latter.

Conversion of wetlands to other land uses is well known to cause large carbon losses via several pathways, but critical data are lacking to evaluate the magnitude of carbon gains from forest regrowth and hydrological restoration. Researchers assume that mangroves are far more efficient at trapping carbon than upland tropical forests, through above and belowground biomass growth and annual turn-over of litter, but data to confirm this is scant.

Country-wide carbon stock estimates for wetlands are still lacking for many countries. Aboveground and belowground pools are almost never measured simultaneously and few models have been developed to simulate carbon and nutrient dynamics in tropical peats and carbon-rich mangrove soils (in mangrove ecosystems, $50-90 \%$ of the total carbon stock is in the soil carbon pool). Only local studies have been conducted to estimate soil carbon stocks, which is a gap of critical importance considering the vast proportion of carbon stored in the organic-rich wetland soils. Countries will potentially be able to include their wetland ecosystems in climate change mitigation mechanisms such as REDD+, when these critical issues are approached.

In general, not much is known about the thresholds within which different wetland ecosystems and species will be able to effectively respond to both 
climatic and anthropogenic changes. Biological inventories need to be advanced to reflect distribution, state and functions within specific ecological assemblages, climatic zones and locations, and change needs to be monitored consistently. Remote sensing and ecological observations in real time can form an important component of integrated biodiversity climate change assessments, as many species might be altering their ranges and phenological responses in ways consistent with relatively small climatic changes. Ecosystem modelling and scenario building can be very useful tools for exploring thresholds and tipping points. However, most of the ecosystem models developed to date are yet to be tested or validated in tropical environments.

Wetland ecosystem vulnerability cannot be detached from the vulnerability of societies that depend on them for their livelihoods and well-being. Degraded wetland ecosystems can increase the vulnerability of communities, which in turn can be driven to engage even more extensively in short-term and exploitative coping strategies (e.g. more intense aquaculture in mangrove ecosystems, which increases the vulnerability of both ecosystems and communities). On the other hand, a secure flow of ecosystem services can help societies adapt to climate variability and change. For example, mangrove ecosystems provide storm and tidal flood protection, and limit erosion and salt water intrusion due to sea-level rise. Peatlands regulate the timing and quantity of water flows (e.g. they gradually release stored water during droughts making it available when communities need it most). Mangroves and peatlands also provide important livelihood goods such as crustaceans, charcoal, fuel wood, timber, bark and resins, which constitute important safety nets for communities when agricultural crops fail due to climate hazards and variability. The vulnerability and value of wetland ecosystem services in different socio-ecological contexts needs to be examined further.

\footnotetext{
The clarification of wetland forest definitions and thematic detail, and maintaining consistency of classifications, will facilitate work at all levels and allow for comparability across spatial and temporal scales. The current IPCC definition of wetlands is also inadequate and needs to be revised, as it now defines wetlands as those areas '.. that do not fall into the forestland, cropland, grassland or settlements categories'. A restructuring of the wetlands category
}

into a subcategory would mean that any wetland system - including those that fall into the forest land, cropland, grassland or settlement categories, could be defined as wetlands, with the appropriate emissions factors and accounting methods applied for belowground carbon stocks and hydrological components. For example, the conversion of wetlands to aquaculture or agriculture would cause wetlands to become sources of greenhouse gases. The IPCC definition should be revised to more accurately reflect a science-based definition of wetlands, such as: 'land that is in undated or saturated by water for all or part of the year (e.g. peatland), at such frequency and duration that under natural conditions it supports organisms adapted to poorly aerated and/ or saturated soil'.

To approach a complex interrelationship between topics and aspects of research and their implications for public policy making, it is imperative to map the existing knowledge while identifying gaps to enhance the network for future collaborative work, as shown in Table 8.1. This way, one can optimise scarce public funds to appropriately scale up the measurement, integrate the assessments and synthesise the results.

\subsection{Consolidation of knowledge and networks}

Available data and approaches urgently need to be consolidated and synthesised. The establishment of permanent plot networks and the creation of a centralised database are necessary to measure and monitor carbon stock dynamics in tropical wetland ecosystems. Synergies need to be created between remote sensing, field and modelling efforts in order to calibrate and validate data, but also to ensure that resources are used in the most efficient manner. Strong collaborative partnerships between universities, institutions and government bodies are necessary for this to materialise.

The scientific community should proceed with the development of standardised methodologies, land classification (use and cover), stratification and protocols to improve comparability of results between studies and reduce confusion. Currently, methodological differences limit comparability. For example, the carbon content of peat soil has been determined by loss on ignition (LOI), wet combustion, and induction furnace method, and 
Table 8.1. Summary of knowledge assessments and identified knowledge gaps to guide research priorities

\begin{tabular}{|c|c|c|}
\hline & Current state & Knowledge gaps and research priorities \\
\hline \multirow[t]{5}{*}{ Land-use change } & \multirow{2}{*}{$\begin{array}{l}\text { Wetlands are under immense pressure } \\
\text { from land-use change. The most prominent } \\
\text { land uses (agriculture, aquaculture, } \\
\text { stand improvement, settlements) have a } \\
\text { considerable impact on wetlands. Even } \\
\text { small changes can cause large effects due } \\
\text { to drainage and reduced canopy. }\end{array}$} & $\begin{array}{l}\text { A better understanding of the long-term } \\
\text { consequences of land-use change and ecosystem } \\
\text { degradation is needed. The cumulative effects of } \\
\text { land-use change and climate change on tropical } \\
\text { wetland ecosystems are not well understood. }\end{array}$ \\
\hline & & \multirow{2}{*}{$\begin{array}{l}\text { A dedicated remote sensing monitoring focus on } \\
\text { land changes with respect to wetlands is needed, } \\
\text { although some large extent studies are available. } \\
\text { Long, consistent time-series processing and } \\
\text { analysis is needed. National monitoring should also } \\
\text { include degradation and increase frequency. }\end{array}$} \\
\hline & \multirow{2}{*}{$\begin{array}{l}\text { Most alternative land uses are not } \\
\text { sustainable. Peat subsidence continues } \\
\text { for as long as land is used for agriculture, } \\
\text { meaning agriculture cannot be sustained } \\
\text { indefinitely. Shrimp ponds on mangrove } \\
\text { converted land have a life span of only } \\
6 \text { years. }\end{array}$} & \\
\hline & & \multirow{2}{*}{$\begin{array}{l}\text { A better understanding and further study is } \\
\text { needed of social vulnerability and perceptions } \\
\text { of change and the behavioural and institutional } \\
\text { aspects of wetland land-use change and ecosystem } \\
\text { degradation. }\end{array}$} \\
\hline & $\begin{array}{l}\text { Land-use change can increase societal } \\
\text { vulnerability to climate change. }\end{array}$ & \\
\hline \multirow[t]{6}{*}{ Carbon stocks } & \multirow{6}{*}{$\begin{array}{l}\text { Major aboveground carbon stock shave } \\
\text { been quantified for a number of sites in } \\
\text { several tropical countries. } \\
\text { A number of allometric equations shave } \\
\text { been developed to quantify aboveground } \\
\text { carbon stocks in tropical mangroves, and } \\
\text { oil palm and Acacia plantations. } \\
\text { Several indicators are available in remote } \\
\text { sensing for biomass and carbon (e.g. } \\
\text { vegetation height, type and cover density) } \\
\text { and soil carbon stocks (e.g. peat depths and } \\
\text { elevation changes). }\end{array}$} & $\begin{array}{l}\text { Country-wide carbon stock estimations are still } \\
\text { lacking for Indonesia and many other tropical } \\
\text { countries. This is especially the case for primary }\end{array}$ \\
\hline & & forests and other land-uses. \\
\hline & & \multirow{2}{*}{$\begin{array}{l}\text { Above and belowground pools are almost never } \\
\text { measured simultaneously, and allometric equations } \\
\text { for both are generally lacking. Few models have } \\
\text { been developed to simulate carbon and nutrient } \\
\text { dynamics in tropical peats and carbon-rich } \\
\text { mangrove soils. Furthermore, the magnitude and } \\
\text { fate of carbon export in dissolved organic carbon } \\
\text { and particulate organic carbon is unknown for } \\
\text { many wetland ecosystems, such as in Indonesia. }\end{array}$} \\
\hline & & \\
\hline & & $\begin{array}{l}\text { In remote sensing, there is a need for field } \\
\text { data calibration and validation and also for } \\
\text { better sampling techniques, upscaling and } \\
\text { standardisation. For soil carbon stocks and change, } \\
\text { only local studies in peatlands are available (not } \\
\text { mangroves) and there is a general need for larger } \\
\text { systemic studies of belowground biomass. }\end{array}$ \\
\hline & & $\begin{array}{l}\text { Data is lacking to evaluate the magnitude of } \\
\text { carbon gains from forest regrowth and hydrological } \\
\text { restoration. }\end{array}$ \\
\hline \multirow[t]{2}{*}{$\begin{array}{l}\text { Greenhouse gas } \\
\text { fluxes }\end{array}$} & $\begin{array}{l}\text { Any land-use on peat that involves } \\
\text { drainage results in net increases } \\
\text { of greenhouse gas emissions that } \\
\text { continue in time, rather than a pulse of } \\
\text { emissions. Nitrous oxide emissions can be } \\
\text { considerably higher when nitrogenous } \\
\text { fertilisers are applied. Substantial } \\
\text { subsidence and emissions can be expected } \\
\text { even at optimal drainage depth. }\end{array}$ & $\begin{array}{l}\text { Little is known about exports of carbon in ground } \\
\text { water. Greenhouse gas fluxes need to be linked } \\
\text { to functional factors including mean water table } \\
\text { depth, land cover and other relevant factors (e.g. } \\
\text { surface soil temperature, fertilisation). Agricultural } \\
\text { lands should be an important area of study. Little } \\
\text { is also known about the greenhouse gas fluxes in } \\
\text { undisturbed peat and also about possible climate } \\
\text { feedbacks. }\end{array}$ \\
\hline & $\begin{array}{l}\text { Unmanaged degraded peat is highly } \\
\text { susceptible to fire. Several indicators are } \\
\text { available in remote sensing for fire which } \\
\text { illustrate activity, burnt area, intensity/ } \\
\text { severity, radiative energy and recovery. }\end{array}$ & $\begin{array}{l}\text { Simultaneous measurements of methane, nitrous } \\
\text { oxide and carbon dioxide flux during fire are } \\
\text { needed. Science should also be advanced in } \\
\text { improving fire prediction. Nation-wide burning } \\
\text { indices and fuel load maps should be developed } \\
\text { that can feed into an early warning system. }\end{array}$ \\
\hline
\end{tabular}


Table 8.1. Continued

\begin{tabular}{|c|c|c|}
\hline & Current state & Knowledge gaps and research priorities \\
\hline \multirow[t]{4}{*}{$\begin{array}{l}\text { Biodiversity, } \\
\text { ecosystem } \\
\text { services and } \\
\text { changes }\end{array}$} & $\begin{array}{l}\text { Several indicators are available for remote } \\
\text { sensing of wetland types and biodiversity, } \\
\text { mainly for monitoring the extent of } \\
\text { different wetland types and identification } \\
\text { of some species. }\end{array}$ & \multirow{2}{*}{$\begin{array}{l}\text { Existing biodiversity maps developed with remote } \\
\text { sensing have inconsistencies that need to be } \\
\text { clarified. The accuracy/detail of maps needs to be } \\
\text { updated and increased. Clear definitions related } \\
\text { to habitat assessments and what to monitor are } \\
\text { needed. Advanced approaches should be applied } \\
\text { for species mapping. Biological inventories of } \\
\text { wetland species need to be further advanced to } \\
\text { reflect ecosystem distribution, state and functions } \\
\text { within specific ecological assemblages and climatic } \\
\text { zones and locations. Ecological observations in real } \\
\text { time are an important component of integrated } \\
\text { climate change biodiversity assessments. }\end{array}$} \\
\hline & $\begin{array}{l}\text { Some evidence exists of the effect of } \\
\text { relatively small changes on wetland } \\
\text { biodiversity (reduction in rainfall may } \\
\text { contribute to the conversion of one tidal } \\
\text { wetland type into another - mangroves } \\
\text { into saltmarshes, for example). However, } \\
\text { different species will respond in different } \\
\text { ways to different stressors. }\end{array}$ & \\
\hline & \multirow[t]{2}{*}{$\begin{array}{l}\text { Some valuations of ecosystem services } \\
\text { other than carbon have been conducted, } \\
\text { mainly related to mangroves. These include } \\
\text { valuation studies of provisioning services } \\
\text { (e.g. fishery productivity, honey, fuel wood) } \\
\text { in Bangladesh and Vietnam and storm/ } \\
\text { tidal flood protection services in India and } \\
\text { Vietnam. }\end{array}$} & $\begin{array}{l}\text { Little is known regarding the thresholds within } \\
\text { which different wetland types will be able } \\
\text { to successfully respond to changes. Models } \\
\text { developed to simulate wetland response to sea- } \\
\text { level rise in temperate systems need to be tested in } \\
\text { tropical environments. Models and scenarios also } \\
\text { need to be advanced in order to explore ecosystem } \\
\text { thresholds under different and cumulative climate } \\
\text { change and anthropogenic pressures. }\end{array}$ \\
\hline & & $\begin{array}{l}\text { More work is needed on the valuation of ecosystem } \\
\text { services and their vulnerability to pressures in } \\
\text { different regions and landscape types, especially in } \\
\text { peatland ecosystems. }\end{array}$ \\
\hline
\end{tabular}

different allometric equations have been employed to estimate aboveground biomass.

It is imperative for standards to include a list of relevant metadata, along with measurements to characterise site conditions. Robust methodology and strong experimental design are essential for quality research.

National coordination mechanisms, data infrastructure and data repositories (including metadata and quality control) could be setup by involving stakeholders from government institutions and nongovernmental, private sector and research organisations. Improved communication among universities should be fostered to develop regional and national research synergies.

To date, about two dozen research and development projects on wetland-related issues are taking place in Indonesia (a full list may be found at http://www. cifor.org/twincam).

\subsection{Scaling up measurements and integrated assessments}

Many wetland areas remain understudied (e.g. West Papua, Indonesia) and research needs to expand in new areas to ensure that a broad spatial distribution and variability of wetland ecosystems are included. Multiple representative sites in different settings with different species, climatic conditions and socioeconomic circumstances need to be explored.

It is also essential to scale up local measurements to regional levels, as the functional scale of wetland ecosystems and the associated drivers of change typically span a broader spatial and temporal range than that at which most research and management projects operate. Integrated wetland management at the appropriate spatial scale must be considered, as, for example, the high hydrological connectivity of wetland ecosystems implies that management upstream has a large impact on the forests downstream. 
Integrated vulnerability assessments at the appropriate spatial scales are also critical for guiding action based on existing knowledge and establishing a strategy for filling critical data gaps, where such gaps are preventing effective planning for wetland ecosystem management. Such assessments can be relevant for both adaptation and mitigation as explained below. Conducting vulnerability assessments is one effective way of identifying specific drivers of change in different wetland socio-ecological systems, as they can improve our understanding of system dynamics. An appropriate framework needs to applied, one that considers the vulnerability of both ecosystems and societies in a holistic manner. A focus on ecosystem services is one pathway for linking the ecological and social factors of vulnerability.

Accurate, remotely sensed and ground-based data acquisition requires considerable financial and human resources. Funding needs to be secured for equipment, transportation, salaries, data analysis and laboratory materials. For instance, laboratory facilities are required for even minimum pre-processing of soil samples to accurately measure carbon density and carbon content.

It is also important for the international community to foster data continuity through national and international programmes since, for example, many tropical countries lack the assets and capacity to maintain consistent satellite observations over time.

\subsection{Science-policy dialogue}

Evidence based on rigorous research needs to be placed within the national policy making cycles of countries harbouring tropical wetland ecosystems. However, science and policy are often disconnected, and bridging this gap is essential to improving wetland management and social well-being. Stronger linkages are also necessary to inform national policy makers about the relevance of ongoing research in tropical wetland ecosystems in different countries.

In many cases, the low level of awareness regarding the relationship between wetland ecosystem services and climate change, and/or the low level of capacity in climate change planning can be important barriers to action. An effective structure for science-policy dialogue can help overcome these barriers.
Science should also strive to supply policy makers with decision-support tools. For example, ecosystem modelling tools can be developed that support exploration of different climate change, land-use and disturbance scenarios, and assess multiple ecosystem services in addition to carbon, such as biodiversity, food security, water resources, and trade-offs between these services.

\subsection{Synergies between adaptation and mitigation}

Even through adaptation and mitigation have been treated separately in both research and policy, action on climate change and wetlands can benefit immensely from a synergistic approach between the two disciplines. For example, research on carbon stock change can inform vulnerability assessments and vice versa. More efforts are however needed to understand and fully take advantage of existing and potential synergies.

Mitigation strategies can facilitate the adaptation of wetland ecosystems to climate change by enhancing their resilience through the reduction of anthropogenic pressures and the conservation of biodiversity. However, mitigation strategies should include additional adaptation measures to reduce the negative impacts of climate change on wetland ecosystems, as climatic pressures can hinder carbon sequestration services or even induce greenhouse gas emissions (e.g. fire in peatlands or mangrove die-back due to sea-level rise).

Adaptation measures can affect carbon stocks positively, by either increasing or maintaining them, and adaptation initiatives can benefit from financial incentives offered by mitigation mechanisms. For example, mangroves simultaneously contribute to protecting coastal areas and to storing carbon. Financial streams from carbon credits could help in ensuring the funding that communities and local institutions need to conserve mangrove ecosystems, which play a critical role in the safety of settlements, food security and livelihoods. However, there may be trade-offs between carbon and local ecosystem services prioritised by communities or institutions, and more research is needed to understand where and when such trade-offs might occur. 
It is imperative that any mitigation initiatives take into consideration the social dimensions of vulnerability, as mitigation projects can have a significant impact on local livelihoods and the adaptive capacity of communities. The conservation of wetland ecosystems for mitigation purposes can result in better provision of ecosystem services, diversified incomes, infrastructure and social services, but it can also result in the exclusion of local communities from the ecosystem services that they depend on, thus increasing their vulnerability to climate change.
A synergistic approach between adaptation and mitigation could be facilitated by international and national incentive mechanisms for mitigation action that integrate adaptation measures. Standards could be applied that evaluate the impacts of mitigation projects on community vulnerability and wellbeing. Ultimately, it is essential to foster knowledge sharing between adaptation and mitigation scientists, decision makers and practitioners. 


\section{References}

Adger, W.N., Kelly, P.M. and Tri, N.H. 1997 Valuing the products and services of mangrove restoration. Commonwealth Forestry Review 76(3): 198-202.

Adiwibowo, A. 2011 Raising sustainable and alternative pathways for empowering poor community resilience in the sinking fish-farmer villages: Jakarta bay experience. Extended abstract for the Workshop on Tropical Wetland Ecosystems of Indonesia: Science Needs to Address Climate Change Adaptation and Mitigation. Bali, Indonesia, 11-14 April 2011.

Alongi, D.M. 2002 Present state and future of the world's mangrove forests. Environmental Conservation 29(3): 331-349.

Anshari, G.Z., Afifudin, M., Nuriman, M., Gusmayanti, E., Arianie, L., Susana, R., Nusantara, R.W., Sugardjito, J. and Rafiastanto, A. 2010 Drainage and land use impacts on changes in selected peat properties and peat degradation in West Kalimantan Province, Indonesia. Biogeosciences 7: 3403-3419.

Badola, R. and Hussain, S. 2005 Valuing ecosystem functions: an empirical study on the storm protection function of Bhitarkanika mangrove ecosystem, India. Environmental Conservation 32, 85-92.

Ballhorn, U., Siegert, F., Mason, M. and Limin, S. 2009 Derivation of burn scar depths and estimation of carbon emissions with LIDAR in Indonesian peatlands. Proceedings of the National Academy of Sciences of the United States of America 106(50): 21213-21218.

Barr, J.G., Engel, S., Fuentes, J.D., Zieman, J.C., O'Halloran, T.L., Smith, T.J. and Anderson, G.H. 2010 Controls on mangrove forestatmosphere carbon dioxide exchanges in western Everglades National Park. Journal of Geophysical Research-Biogeosciences 115, G02020.
Baum, A., Rixen, T. and Samiaji, J. 2007 Relevance of peat draining rivers in central Sumatra for the riverine input of dissolved organic carbon into the ocean. Estuarine Coastal and Shelf Science 73: $563-570$.

Berger, U., Rivera-Monroy, V.H., Doyle, T.W., Dahdouh-Guebas, F., Duke, N.C., FontalvoHerazo, M.L., Hildenbrandt, H., Koedam, N., Mehlig, U., Piou, C. et al. 2008 Advances and limitations of individual-based models to analyze and predict dynamics of mangrove forests: A review. Aquatic Botany 89: 260-274.

Cairns Jr,J. 2004 Ecological tipping points: A major challenge for experimental sciences. Asian Journal of Experimental Sciences 18(1): 1-16.

Charman, D. 2002 Peatlands and environmental change. John Wiley and Sons, London.

Chave, J., Andalo, C., Brown, S., Cairns, M.A., Chambers, J.Q., Eamus, D., Fölster, H., Fromard, F., Higuchi, N., Kira, T. et al. 2005 Tree allometry and improved estimation of carbon stocks and balance in tropical forests. Oecologia 145: 87-99.

Chimner, R.A. and Ewel, K.C. 2005 A tropical freshwater wetland: II. Production, decomposition, and peat formation. Wetlands Ecology and Management 13: 671-684.

Corley, R.H.V., Hardon, J.J. and Tan, G.Y. 1971 Analysis of growth of the oil palm (ElaeisguineensisJacq.) 1. Estimation of growth parameters and application in breeding. Euphytica 20: 307-315.

Costanza, R., Pérez-Maqueo, O., Martinez, M.L., Sutton, P., Anderson, S.J. and Mulder, K. 2008 The value of coastal wetlands for hurricane protection. Ambio 37(4): 241-248.

Couwenberg, J., Dommain, R. and Joosten, H. 2010 Greenhouse gas fluxes from tropical peatlands 
in south-east Asia. Global Change Biology 16: 1715-1732.

Crooks, S., Herr, D., Tamelander, J., Laffoley, D. and Vandever, J. 2011 Mitigation of climate change through restoration and management of coastal wetlands and near-shore marine ecosystems: Challenges and opportunities. Environment Department Paper 121, World Bank, Washington D.C., USA.

Das, S. and Vincent, J.R. 2009 Mangroves protected villages and reduced death toll during Indian super cyclone. Proceedings of the National Academy of Sciences of the United States of America, 106(18): 7357-7360.

Dawson, T.P., Jackson, S.T., House, J.I., Prentice, I.C. and Mace, G.M. 2011 Beyond Predictions: Biodiversity Conservation in a Changing Climate. Science, 332(6025): 53-58

De la Cruz, A.A. 1982 Wetland uses in the tropics and their implications on the world carbon cycle. Wetlands 2: 1-20.

De la Cruz, A.A. 1986 Tropical wetlands as a carbon source. Aquatic Botany 25: 109-115.

Dommain, R., Couwenberg, J. and Joosten, H. 2011 Development and carbon sequestration of tropical peat domes in south-east Asia: Links to post-glacial sea-level changes and Holocene climate variability. Quaternary Science Reviews 30: 999-1010.

Donato, D., Kauffman,J.B., Murdiyarso, D., Kurnianto, S., Stidham, M. and Kanninen, M. 2011 Mangroves among the most carbon rich forests of the tropics. Nature Geoscience 4: 293-297.

Duke, N.C. 2007 A world without mangroves? Science 317: 41-42.

Duke, N. 2011 Can mangroves cope with climate change and local human pressure? Maybe, if communities respond effectively. Extended abstract for the Workshop on Tropical Wetland Ecosystems of Indonesia: Science Needs to Address Climate Change Adaptation and Mitigation. Bali, Indonesia, 11-14 April.

Ellison, J., Rubens, J., Cooks, J., Fiu, M. and Tchikangwa, B. 2010 Climate change vulnerability assessment and adaptation in mangrove systems. Communication at Deltas in Times of Climate Change, September 2010. Rotterdam, Netherlands.

Fargione, J., Hill, J., Tilman, D., Polasky, S. and Hawthorne, P. 2008 Land clearing and the biofuel carbon debt. Science 319, 1235-1238.
Fatoyinbo, T.E., Simard, M., Washington-Allen, R.A. and Shugart, H.H. 2008 Landscape-scale extent, height, biomass, and carbon estimation of Mozambique's mangrove forests with Landsat ETM+ and Shuttle Radar Topography Mission elevation data. Journal of Geophysical Research 113, G02S06, doi:10.1029/2007JG000551.

Field, R.D., van der Werf, G.R. and Shen, S.S.P. 2009 Human amplification of drought-induced biomass burning in Indonesia since 1960. Nature Geoscience 2: 185-188.

Frolking, S., Roulet, N.T., Tuittila, E., Bubier, J.L., Quillet, A., Talbot, J. and Richard, P.J.H. 2010 A new model of Holocene peatland net primary production, decomposition, water balance, and peat accumulation. Earth System Dynamics Discussions 1: 115-167.

Füssel, H.M. and Klein, R.J.T. 2006 Climate change vulnerability assessments: An evolution of conceptual thinking. Climatic Change 75(3): 301-329.

Germer, J. and Sauerborn, J. 2007 Estimation of the impact of oil palm plantation establishment on greenhouse gas balance. Environment, Development and Sustainability 10: 697-71.

Giri, C., Ochieng, E., Tieszen L.L., Zhu, Z., Singh, A., Loveland, T., and Duke, N.C. 2010 Status and distribution of mangrove forest of the world using earth observation satellite data. Global Ecology and Biogeography 20(1): 154-159.

GOFC-GOLD 2010 A sourcebook of methods and procedures for monitoring and reporting anthropogenic greenhouse gas emissions and removals caused by deforestation, gains and losses of carbon stocks in forest remaining forests, and forestation. GOFC-GOLD report version COP16-1. GOFC-GOLD Project Office, Natural Resources Canada, Alberta, Canada.

Heimann, M. and Reichstein, M. 2008 Terrestrial ecosystem carbon dynamics and climate feedbacks. Nature 451: 289-292.

Henson, I.E. 2009 Modelling carbon sequestration and greenhouse gas emissions associated with oil palm cultivation and land-use change in Malaysia. A re-evaluation and a computer model. The Malaysian Palm Oil Board, Washington, D.C., USA.

Hergoualc'h, K. and Verchot, L.V. 2011 Stocks and fluxes of carbon associated with land use change in southeast Asian tropical peatlands: A review. 
Global Biogeochemical Cycles 25: GB2001, doi:10.1029/2009GB003718,2011

Heriansyah, I., Miyakuni, K., Kato, T., Kiyono, Y. and Kanazawa, Y. 2007 Growth characteristics and biomass accumulations of Acacia mangium under different management practices in Indonesia. Journal of Tropical Forest Science 19: 226-235.

Hirano, T., Segah, H., Harada, T., Limin, S., June, T., Hirata, R. and Osaki, M. 2007 Carbon dioxide balance of a tropical peat swamp forest in Kalimantan, Indonesia. Global Change Biology 13: 412-425.

Hirano, T., Jauhiainen, J., Inoue, T. and Takahashi, H. 2009 Controls on the carbon balance of tropical peatlands. Ecosystems 12(6): 873-887.

Hirata, Y., Furuya, N., Suzuki, M. and Yamamoto, H. 2009 Airborne laser scanning in forest management: Individual tree identification and laser pulse penetration in a stand with different levels of thinning. Forest Ecology and Management 258: 752-760.

Hiratsuka, M., Toma, T., Heriansyah, I. and Morikawa, Y. 2003 A general allometric equation for estimating biomass in Acacia mangium plantations. In: College of forestry and natural resources, U.o.t.P. (ed.), Carbon sequestration and clean development mechanism, 212218. Proceedings of the 2003 International Conference on Tropical Forests and Climate Change, Manila, Philippines.

Hooijer, A., Page, S., Canadell, J.G., Silvius, M., Kwadijk, J., Wösten, H. and Jauhiainen, J. 2010 Current and future $\mathrm{CO}_{2}$ emissions from drained peatlands in southeast Asia. Biogeosciences 7: 1505-1514.

Hooijer, A., Silvius, M., H. Wösten, H. and Page, S. 2006 PEAT-CO ${ }_{2}$ : Assessment of $\mathrm{CO}_{2}$ emissions from drained peatlands in SE Asia. Technical Report Q3943, Delft Hydraulics. Delft.

Huang, Y., Sun, W., Zhang, W., Yu, Y., Su, Y. and Song, C. 2010 Marshland conversion to cropland in northeast China from 1950 to 2000 reduced the greenhouse effect. Global Change Biology 16: 680-695.

Iftekhar, M.S. and Takama, T.2008 Perceptions of biodiversity, environmental services, and conservation of planted mangroves: A case study on Nijhum Dwip Island, Bangladesh. Wetlands Ecology and Management 16(2): 119-137.

Inubushi, K., Furukawa, Y., Hadi, A., Purnomo, E. and Tsuruta, H. 2003 Seasonal changes of $\mathrm{CO}_{2}$,
$\mathrm{CH}_{4}$ and $\mathrm{N}_{2} \mathrm{O}$ fluxes in relation to land-use change in tropical peatlands located in a coastal area of South Kalimantan. Chemosphere 52(3): 603-608.

IPCC 1996 Revised 1996 IPCC guidelines for national greenhouse gas inventories. Edited by: Houghton, J.T., Meira Filho, L.G., Lim, B., Treanton, K., Mamaty, I., Bonduki, Y., Griggs, D.J. and Callender, B.A. UK Meteorological Office, Bracknell, UK.

IPCC 2001 Climate change 2001: Synthesis report. Cambridge University Press, Cambridge, UK.

IPCC 2003 Good practice guidance for land use, land-use change and forestry. Prepared by the National Greenhouse Gas Inventories Programme, edited by: Penman, J., Gytarsky, M., Hiraishi, T., Krug, T., Kruger, D., Pipatti, R., Buendia, L., Miwa, K., Ngara, T., Tanabe, K. et al. IGES, Japan.

IPCC 2006 Guidelines for national greenhouse gas inventories, Volume 4. Agriculture, forestry, and other land use. Prepared by the National Greenhouse Gas Inventories Programme, edited by: Eggleston, H.S., Buendia, L., Miwa, K., Ngara, T. and Tanabe, K. IGES, Japan.

Jaenicke, J., Rieley, J.O., Mott C., Kimman P. and Siegert, F. 2008 Determination of the amount of carbon stored in Indonesian peatlands. Geoderma 147: 151-158.

Jauhiainen, J., Hooijer, A. and Page, S.E. 2012 Carbon dioxide emissions from an Acacia plantation on peatland in Sumatra, Indonesia. Biogeosciences 9: 617-630.

Jauhiainen, J., Limin, S., Silvennoinen, H. and Vasander, H. 2008 Carbon dioxide and methane fluxes in drained tropical peat before and after hydrological restoration. Ecology 89: 3503-3514.

Jauhiainen, J., Takahashi, H., Heikkinen, J.E.P., Martikainen, P.J. and Vasander, H. 2005 Carbon fluxes from a tropical peat swamp forest floor. Global Change Biology 11: 1788-1797.

Kato, T. and Tang, Y. H. 2008 Spatial variability and major controlling factors of $\mathrm{CO}_{2}$ sink strength in Asian terrestrial ecosystems: Evidence from eddy covariance data. Global Change Biology 14: 2333-2348.

Kauffman, J.B. and Cole. T. 2010 Micronesian mangrove forest structure and tree response to a severe typhoon. Wetlands 30: 1077-1084.

Kauffman, J.B. and Donato, D.C. 2011 Protocols for the measurement, monitoring, and reporting 
of structure, biomass, and carbon stocks in mangrove forests. Working Paper No.86. CIFOR, Bogor 40p.

Kelly, P.M. and Adger, W.N. 2000 Theory and practice in assessing vulnerability to climate change and facilitating adaptation. Climatic Change 47: 325-352.

Khalid, H., Zin, Z.Z. and Anderson, J.M. 1999 Quantification of oil palm biomass and nutrient value in a mature plantation. I. Above-ground biomass. Journal of Oil Palm Research 1: 23-32.

Koh, L.P. and Ghazoul, J. 2010 Spatially explicit scenario analysis for reconciling agricultural expansion, forest protection, and carbon conservation in Indonesia. PNAS 107: 11140-11144.

Koh, L.P., Miettinen, J., Liew, S.C, and Ghazoul, J. 2011 Remotely sensed evidence of tropical peatland conversion to oil palm. www.pnas.org/ cgi/doi/10.1073/pnas.1018776108.

Komiyama, A., Ong, J.E. and Poungparn, S. 2008 Allometry, biomass, and productivity of mangrove forests: A review. Aquatic Botany 89: 128-137.

Langley, J.A. and Megonigal, J.P. 2010 Ecosystem response to elevated $\mathrm{CO}_{2}$ limited by nitrogeninduced community shift. Nature 466:96-99.

Langmann, B. and Heil, A. 2004 Release and dispersion of vegetation and peat fire emissions in the atmosphere over Indonesia 1997/1998. Atmos. Chem. Phys. Discuss. 4: 2117-2159.

Langner, A., Miettinen, J. and Siegert, F. 2007 Land cover change 2002-2005 in Borneo and the role of fire derived from MODIS imagery. Global Change Biology 13: 2329-2340.

Langner, A. and Siegert, F. 2009 Spatiotemporal fire occurrence in Borneo over a period of 10 years. Global Change Biology 15: 48-62.

Le Quéré, C., Raupach, M.R., Canadell, J.G., Marland, G., et al. 2009 Trends in the sources and sinks of carbon dioxide. Nature Geoscience 2: 831-836.

Li, W., Dickinson, R.E., Fu, R., Niu, G-Y., Yang, Z-L., Canadell, J.G. 2007 Future precipitation changes and their implications for tropical peatlands, Geophys. Res. Lett. 34, L01403, doi:10.1029/2006GL028364.

Locatelli, B., Kanninen, M., Brockhaus, M., Colfer, C.J.P., Murdiyarso, D. and Santoso, H. 2008 Facing an uncertain future: How forests and people can adapt to climate change. Forest Perspectives 5: 1-86.
Maltby, E. and Immirzi, P. 1993 Carbon dynamics in peatlands and other wetland soils regional and global perspectives. Chemosphere 27(6): 999-1023.

Manuri, S., Putra, C.A.S., Saputra, A.D. 2011 Tehnik Pendugaan Cadangan Karbon Hutan. Merang REDD Pilot Project, German International Cooperation - GIZ, Palembang, Indonesia, p. 105.

Marten, G.G. 2005 Environmental tipping points: A new paradigm for restoring ecological security. Journal of Policy 20: 75-87.

MEA (Millennium Ecosystem Assessment), 2005 Ecosystems and Human Well-being: Synthesis. Island Press, Washington, DC.

Melling, L., Hatano, R. and Goh, K.J. 2005

Methane fluxes from three ecosystems in tropical peatland of Sarawak, Malaysia. Soil Biology and Biochemistry 37: 1445-1453.

Melling, L., Hatano, R. and Goh, K.J. 2007 Nitrous oxide emissions from three ecosystems in tropical peatland of Sarawak, Malaysia. Soil Science and Plant Nutrition 53: 792-805.

Miettinen, J. and Liew, S.C. 2010a Degradation and development of peatlands in peninsular Malaysia and in the islands of Sumatra and Borneo since 1990. Land Degradation and Development 21: 285-296.

Miettinen, J. and Liew, S.C. 2010b Status of peatland degradation and development in Sumatra and Kalimantan. Ambio 39: 394-401.

Miettinen, J., Shi, C. and Liew, S.C. 2012 Two decades of destruction in Southeast Asia's peat swamp forests. Frontiers in Ecology and the Environment 10(3): 124-128.

Miyajima, T., Wada, E., Hanba, Y.T. and Vijarsorn, P. 1997 Anaerobic mineralization of indigenous organic matter and methanogenesis in tropical wetland soils. Geochimicaet Cosmochimica Acta 61: 3739-3751.

Moore, S.,Gauci, V.,Evans, C.D. and Page, S.E. 2011 Fluvial organic carbon losses from a Bornean blackwater river. Biogeosciences 8: 901-909.

Morris, J.T., Sundareshwar, P.V., Nietch, C.T., Kjerfve, B. and Cahoon, D.R. 2002 Responses of coastal wetlands to rising sea level. Ecology 83: 2869-2877.

Murayama, S. and Bakar, Z.A. 1996a Decomposition of tropical peat soils -1 . Decomposition kinetics of organic matter of peat soils. Japan Agricultural Research Quarterly 30: 145-151. 
Murayama, S. and Bakar, Z.A. 1996b Decomposition of tropical peat soils -2 . Estimation of in situ decomposition by measurement of $\mathrm{CO}_{2}$ flux. Japan Agricultural Research Quarterly 30: 153-158.

Murdiyarso, D., Donato, D., Kauffman, J.B., Kurnianto, S., Stidham, M. and Kanninen, M. 2009 Carbon storage in mangrove and peatland ecosystems. Working Paper 48, Center for International Forestry Research, Bogor, Indonesia.

Murdiyarso, D., Hergoualc'h, K. and Verchot, L.V. 2010 Opportunities for reducing greenhouse gas emissions in tropical peatlands. Proceedings of the National Academy of Sciences of the United States of America 107: 19655-19660.

Mustelin, J., Klein, R.G., Assaid, B., Sitari, T., Khamis, M., Mzee, A. and Haji, T. 2010 Understanding current and future vulnerability in coastal settings: Community perceptions and preferences for adaptation in Zanzibar, Tanzania. Population and Environment 31(5): 371-398.

Nicholls, R., Wong, P., Burkett, V., Woodroffe, C. and Hay, J. 2008 Climate change and coastal vulnerability assessment: Scenarios for integrated assessment. Sustainability Science 3(1): 89-102

Orr, M.K., Crooks, S. and William, P.B. 2003 Issues in San Francisco estuary tidal restoration: Will restored tidal marshes be sustainable? San Francisco and Watershed Science 1: 108-142.

Page, S.E., Siegert, F.,Rieley, J.O., Boehm, H.D.V., Jaya, A. and Limin, S. 2002 The amount of carbon released from peat and forest fires in Indonesia during 1997. Nature 420: 61-65.

Page, S.E., Rieley, J.O. and Banks, C.J. 2011 Global and regional importance of the tropical peatland carbon pool. Global Change Biology 17(2): 798-818.

Posa M.R.C., Wijedasa, L.S., Corlett, R.T. 2011 Biodiversity and conservation of tropical peat swamp forests. BioScience 61(1): 49-57.

Rahman, A.F., Didan, K. and Dragoni, D. In review. Tracking mangrove degradation and regrowth in Kalimantan with time-series of high fidelity MODIS imagery. Remote Sensing of Environment.

Reyes, E., Martin, J.F., White, M.L., Day, J.W. and Kemp, G.P. 2003 Habitat changes in the Mississippi delta: Future scenarios and alternatives. In: Costanza, R. andVoinov,A. (eds.) Landscape simulation modeling: A spatially explicit, dynamic approach. Springer-Verlag,New York, USA. p. 119-142
Rieley, J.O., Wüst, R.A.J., Jauhiainen, J., Page, S.E., Wösten, H., Hooijer, A., Siegert, F., Limin, S.H., Vasander, H. and Stahlhut, M. 2008 Tropical peatlands: Carbon stores, carbon gas emissions and contribution to climate change processes. In: Strack, M. (ed.) Peatlands and climate change, 148-181. International Peat Society, Jyväskylä, Finland.

RSPO 2007 RSPO Principles and criteria for sustainable palm oil production. http://www. rspo.org/files/resource_centre/RSPO $\% 20$ Principles\%20\&\%20Criteria\%20Document.pdf (23 March 2012).

Saenger, P. 2002 Mangrove ecology, silviculture, and conservation. Kluwer Academic Publishers.

Sanderson, S. and Turner, B.L. 1994 Politicaleconomic institutions. Cambridge University Press, Cambridge, UK.

Santoso, H., Tjiu A. and Muhammad, A. 2011 Vulnerability of ecosystem dependent villagers to climate variability: a case study from two villages by the Sentarum Lake, Kalimantan. Extended abstract for the Workshop on Tropical Wetland Ecosystems of Indonesia: Science Needs to Address Climate Change Adaptation and Mitigation, Bali, Indonesia, 11-14 April.

Siegert, F., Ruecker, G., Hinrichs, A. and Hoffmann, A. A. 2001 Increased damage from fires in logged forests during droughts caused by $\mathrm{El}$ Nińo. Nature 414: 437-440.

Simard, M., Pinto, N., Fisher, J., Baccini, A. 2011 Mapping forest canopy height globally with spaceborne lidar. Journal of Geophysical Research 116, G04021, doi:10.1029/2011JG001708.

Singh, K. 2007 Climate change, sea-level rise and the case for saltmarsh restoration in the Bay of Fundy, Canada. Environments 35(2): 71-84.

Slootweg, R. and Kolhoff, A. 2008 Valuation of Ecosystem services and strategic environmental assessment: Lessons from influential cases. Netherlands Commission for Environmental Assessment, Utrecht, The Netherlands.

Smith, J., Gottschalk, P., Bellarby, J., Chapman, S., Lilly, A., Towers, W., Bell, J., Coleman, K., Nayak, D., Richards, M. et al. 2010 Estimating changes in Scottish soil carbon stocks using ECOSSE. I. Model description and uncertainties. Climate Research 45: 179-192.

Smith, T.J. and Whelan, K.R.T., 2006 Development of allometric relations for three mangrove species in south Florida for use in the Greater Everglades Ecosystem restoration. Wetlands Ecology and 
Management 14: 409-419. Sorenson, K.W. 1993 Indonesian peat swamp forests and their role as a carbon sink. Chemosphere 27(6): 1065-1082.

Sorensen K.W. 1993 Indonesian peat swamp forest and their role as carbon sink. Chemosphere 27: 1065-1082.

Sukardjo, S. 2010 The South China Sea mangroves: Ecology, social and uses, natural and human induced stresses information in Indonesia. LIPI. Bogor.

Sukardjo, S. 2011 Vulnerability of mangroves in Indonesia to climate change: A view from a mangrove ecologist. Extended abstract for the Workshop on Tropical Wetland Ecosystems of Indonesia: Science Needs to Address Climate Change Adaptation and Mitigation, Bali, Indonesia, 11-14 April.

Suyanto, S., Applegate, G., Permana, R.P., Khususiyah, N. and Kurniawan, I. 2004 The role of fire in changing land use and livelihoods in Riau-Sumatra. Ecology and Society 9(1): 15. http://www.ecologyandsociety.org/vol9/iss1/ $\operatorname{art15/(24~March~2012).~}$

Syvitski, J.P.M., Kettner, A.J., Overeem, I., Hutton, E.W.H., Hannon, M.T., Brakenridge, G.R., Day, J., Vorosmarty, C., Saito, Y., Giosan, L. et al. 2009 Sinking deltas due to human activities. Nature Geoscience 2(10): 681-686.

Taconni, L. 2003 Fires in Indonesia: Causes, costs, and policy implications. CIFOR Occasional Paper no. 38. Center for International Forestry Research, Bogor, Indonesia.

Takakai, F., Morishita, T., Hashidoko, Y., Darung, U., Kuramochi, K., Dohong, S., Limin, S.H. and Hatano, R. 2006 Effects of agricultural land-use change and forest fire on $\mathrm{N}_{2} \mathrm{O}$ emission from tropical peatlands, Central Kalimantan, Indonesia. Soil Science and Plant Nutrition 52: 662-674.

TEEB 2009 The Economics of Ecosystems and Biodiversity for National and International Policy Makers - Summary: Responding to the Value of Nature. The Economics of Ecosystems and Biodiversity, United Nations Environment Programme, Nairobi, Kenya.

Tri, N.H., Adger, W. and Kelly, P. 1998 Natural resource management in mitigating climate impacts: The example of mangrove restoration in Vietnam. Global Environmental Change 8(1): 49-61.

Turner, R.K., Burgess, D., Hadley, D., Coombes, E. and Jackson, N. 2006 Coastal management in the 21st century: Coping strategies for vulnerability reduction. CSERGE Working Paper ECM 06-04. School of Environmental Sciences University of East Anglia, Norwich UK. van der Werf, G.R., Dempewolf, J., Trigg, S.N., Randerson, J.T., Kasibhatla, P.S., Gigliof, L., Murdiyarso, D., Peters, W., Morton, D.C., Collatz, G.J. et al. 2008 Climate regulation of fire emissions and deforestation in equatorial Asia. Proceedings of the National Academy of Sciences of the United States of America 105: 20350-20355.

van Noordwijk, M., Dewi, S., Khasanah, N.M., Ekadinata, A., Rahayu, S., Caliman, J.P., Sharma, M. and Suharto, R. 2010 Estimating the carbon footprint of biofuel production from oil palm: Methodology and results from two sites in Indonesia. Second International Conference on Oil Palm and Environment, Bali, Indonesia, 23-25 February.

Walton, M.E.M., Samonte-Tan, G.P.B., Primavera, J.H.G., Edwards-Jones, G. and Le Vay, L. 2006 Are mangroves worth replanting? The direct economic benefits of a communitybased reforestation project. Environmental Conservation 33: 335-343.

Watanabe, A., Purwanto, B.H., Ando, H., Kakuda, K. and Jong, F.S. 2009 Methane and $\mathrm{CO}_{2}$ fluxes from an Indonesian peatland used for sago palm (MetroxylonsaguRottb.) cultivation: Effects of fertilizer and groundwater level management. Agriculture Ecosystems and Environment 134: 14-18.

Wichtmann, W., Tanneberger, F., Wichmann, S. and Joosten, H. 2010 Paludi culture is paludi future: Climate, biodiversity and economic benefits from agriculture and forestry on rewetted peatland. Peatlands International 1: 48-51.

World Bank 2008 Project appraisal document on a proposed purchase of emission reduction by the Biocarbon Fund and other carbon funds. Report no. 45642-TT. Nariva wetland restoration and carbon sequestration project,Trinidad and Tobago.

Wösten, H., Hooijer, A., Siderius, C., Satriadi Rais, D., Idris, A. and Rieley, J.O. 2006 Tropical peatland water management modelling of the Air Hitam Laut catchment in Indonesia. International Journal of River Basin Management 4: 233-244. 


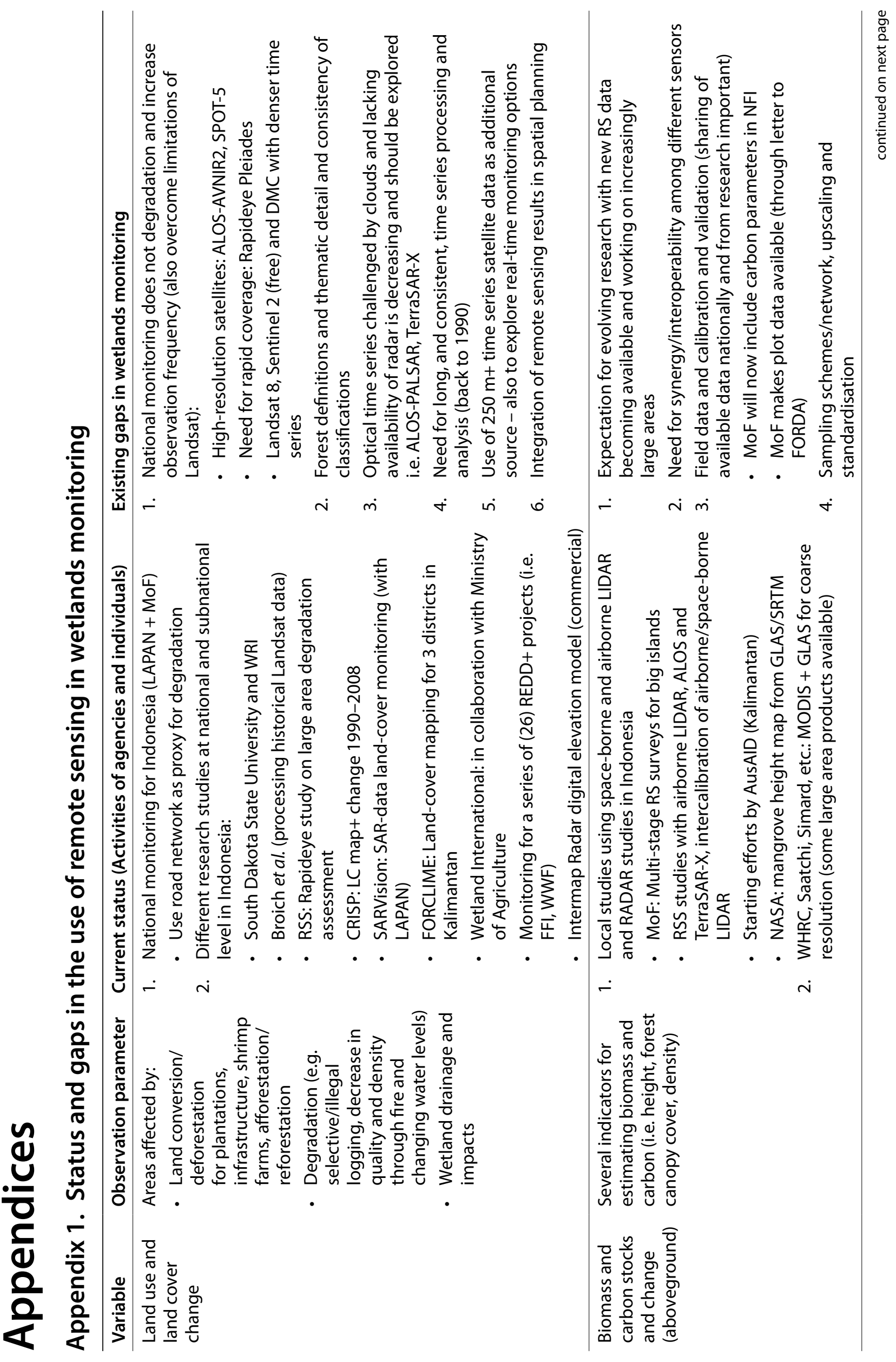




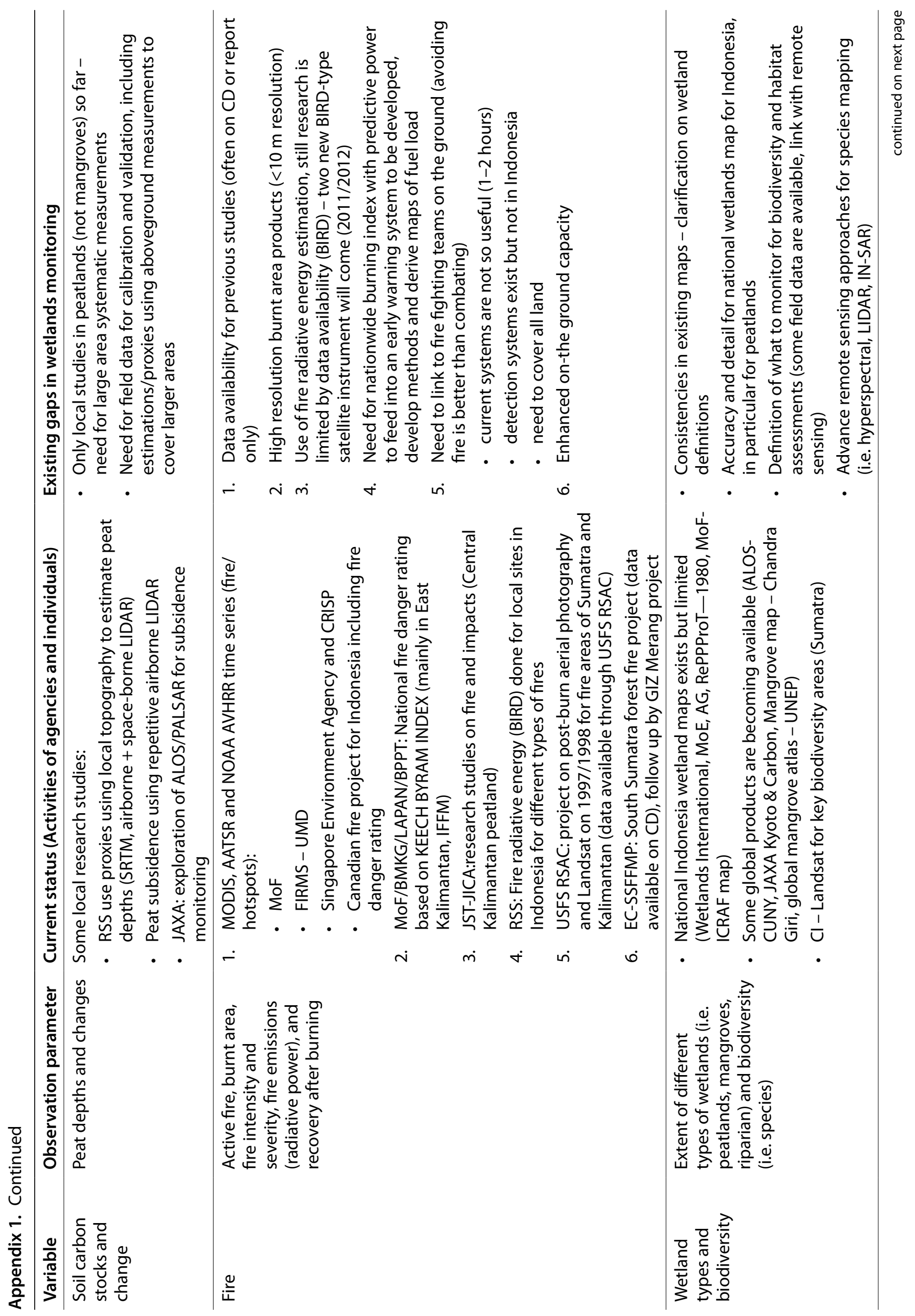




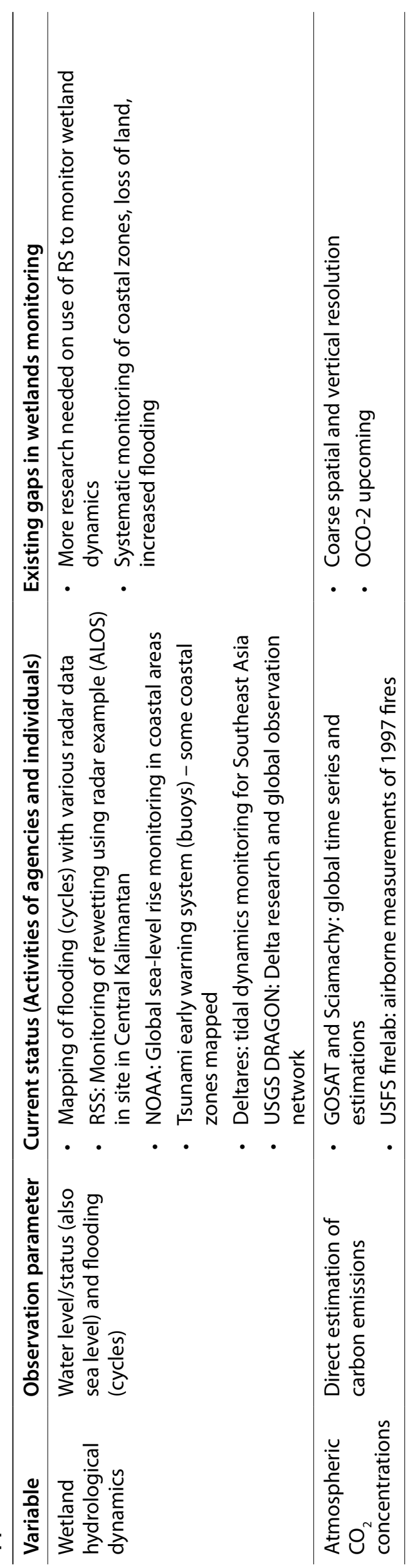




\begin{tabular}{|c|c|c|}
\hline No. & Name & Institution \\
\hline 1. & Adiwibowo, Andrio & University of Indonesia, Jakarta \\
\hline 2. & Agus, Cahyono & University of GadjahMada, Faculty of Forestry, Yogyakarta \\
\hline 3. & Agus, Fahmuddin & Indonesian Soil Research Institute, Ministry of Agriculture, Bogor \\
\hline 4. & Anas, Iswandi & Bogor Agricultural University, Faculty of Agriculture, Bogor \\
\hline 5. & Anshari, Gusti & University of Tanjungpura, Pontianak \\
\hline 6. & Applegate, Grahame & Indonesian-Australia Forest Carbon Partnership (IAFCP), Jakarta \\
\hline 7. & Bonneau, Xavier & CIRAD, Jakarta \\
\hline 8. & Canadell, Pep & $\begin{array}{l}\text { CSIRO Marine and Atmospheric Research, Global Carbon Project, } \\
\text { Australia }\end{array}$ \\
\hline 9. & Cobb, Alex & $\begin{array}{l}\text { Singapore-MIT Alliance for Research and Technology, } \\
\text { Singapore }\end{array}$ \\
\hline 10. & Crooks, Stephen & ESA PWA, USA \\
\hline 11. & D’Arcy, Laura & Zoological Society of London - Indonesia Programme, Bogor \\
\hline 12. & Darusman, Taryono & Starling Resources, Bali \\
\hline 13. & Dewantama, Iwan & SEKALA, Bali \\
\hline 14. & Dharmawan, I Wayan S. & $\begin{array}{l}\text { FORDA, Center for Forest Conservation and Rehabilitation Research and } \\
\text { Development, Bogor }\end{array}$ \\
\hline 15. & Duke, Norman C. & University of Queensland, Australia \\
\hline 16. & Emmer, Igino & Silvestrum, The Netherlands \\
\hline 17. & Engel, Victor & Everglades National Park, South Florida Natural Resources Center, USA \\
\hline 18. & Fatoyinbo, Temilola E. & NASA Goddard Space Flight Center, USA \\
\hline 19. & Fauzana & Dewan Nasional Perubahan Iklim (DNPI), Jakarta \\
\hline 20. & Fisher, Micah & United States Forest Service, USA \\
\hline 21. & Frolking, Steve & University of New Hampshire, USA \\
\hline 22. & Garnier, Fabien & Planete Urgence, Medan \\
\hline 23. & Ginoga, Krisfianti L. & FORDA, Climate Change and Policy Research Development Centre, Bogor \\
\hline 24. & Hadriyanto, Deddy & Mulawarman University, Center for Climate Studies, Samarinda \\
\hline 25. & Handayani, Etik P. & Sekolah Tinggi Pertanian Dharma Wacana, Metro, Lampung \\
\hline 26. & Harrison, Mark E. & $\begin{array}{l}\text { OuTrop, Center for International Cooperation in Sustainable } \\
\text { Management of Tropical Peatland (CIMTROP), Palangkaraya }\end{array}$ \\
\hline 27. & Hergoualc'h, Kristell & CIFOR, Bogor \\
\hline 28. & Hernowo, Basah & Bappenas, Jakarta \\
\hline 29. & Herold, Martin & $\begin{array}{l}\text { University of Wageningen, Laboratory of Geo-Information Science and } \\
\text { Remote Sensing, The Netherlands }\end{array}$ \\
\hline 30. & Hills, Terry & Conservation International, Asia-Pacific Program, Australia \\
\hline 31. & Hirata, Yasumasa & Forest and Forest Product Research Institute (FFPRI), Japan \\
\hline 32. & Hirose, Kazuyo & Hokkaido University, Center for Sustainability Science (CENSUS), Japan \\
\hline 33. & Hooijer, Aljosja & Deltares, The Netherlands \\
\hline 34. & Husen, Edi & Indonesian Soil Research Institute, Ministry of Agriculture, Bogor \\
\hline
\end{tabular}


Appendix 2. Continued

\begin{tabular}{|c|c|c|}
\hline No. & Name & Institution \\
\hline 35. & Husson, Simon & OuTrop, CIMTROP, Palangkaraya \\
\hline 36. & Hutabarat, Joseph A. & Indiana University, USA \\
\hline 37. & Jauhiainen, Jyrki & University of Helsinki, Finland \\
\hline 38. & Joosten, Hans & $\begin{array}{l}\text { University of Greifswald, Institute of Botany and Landscape Ecology, } \\
\text { Germany }\end{array}$ \\
\hline 39. & Kauffman, J. Boone & United States Forest Service, Northern Research Station, USA \\
\hline 40. & Kawaroe, Mujizat & $\begin{array}{l}\text { Bogor Agricultural University, Faculty of Fishery and Marine Sciences, } \\
\text { Bogor }\end{array}$ \\
\hline 41. & Kholibrina, Cut Rizlani & Balai Penelitian Kehutanan Aek Nauli, Pematang Siantar \\
\hline 42. & Krisnawati, Haruni & $\begin{array}{l}\text { FORDA, Center for Forest Conservation and Rehabilitation Research and } \\
\text { Development, Bogor }\end{array}$ \\
\hline 43. & Kurnianto, Sofyan & CIFOR, Bogor \\
\hline 44. & Kusmana, Cecep & Bogor Agricultural University, Faculty of Forestry, Bogor \\
\hline 45. & Maswar & Indonesian Soil Research Institute, Ministry of Agriculture, Bogor \\
\hline 46. & Matanubun, Hubertus & University of Papua, Manokwari \\
\hline 47. & Miettinen, Jukka I. & Centre for Remote Imaging, Sensing and Processing (CRISP), Singapore \\
\hline 48. & Muliastra, Ketut Deddy & SEKALA, Bali \\
\hline 49. & Murdiyarso, Daniel & CIFOR, Bogor \\
\hline 50. & Naito, Rumi & Starling Resources, Bali \\
\hline 51. & Nursal, Wim I. & CIFOR, Bogor \\
\hline 52. & Osaki, Mitsuru & Hokkaido University, Research Faculty of Agriculture, Japan \\
\hline 53. & Rossé, Morten & McKinsey \& Company, Jakarta \\
\hline 54. & Persch, Sebastian & CIFOR, Bogor \\
\hline 55. & Pramova, Emilia & CIFOR, Bogor \\
\hline 56. & Purbopuspito, Joko & University of Sam Ratulangi, Faculty of Agriculture, Manado \\
\hline 57. & Rahayu, Nur Hygiawaty & Bappenas, Jakarta \\
\hline 58. & Rahman, Faiz & Indiana University, Department of Geography, USA \\
\hline 59. & Ridarso, Eko & SEKALA, Bali \\
\hline 60. & Romijn, Erika & $\begin{array}{l}\text { University of Wageningen, Laboratory of Geo-Information Science and } \\
\text { Remote Sensing, The Netherlands }\end{array}$ \\
\hline 61. & Rumapea, Mirna & DNPI, Jakarta \\
\hline 62. & Rush, Bill & United States Forest Service, Jakarta \\
\hline 63. & Ryan, Zoe & Fauna and Flora International, Australia \\
\hline 64. & Saharjo, Bambang Hero & Bogor Agricultural University, Faculty of Forestry, Bogor \\
\hline 65. & Sakuntaladewi, Niken & FORDA, Climate Change and Policy Research Development Centre, Bogor \\
\hline 66. & Santoso, Heru & LIPI, Research Centre for Geotechnology, Bandung \\
\hline 67. & Segah, Hendrik & Hokkaido University, CENSUS, Japan \\
\hline 68. & Siegert, Florian & RSS GmbH and GeoBio-Center LMU, Germany \\
\hline 69. & Simbolon, Herwint & LIPI, Research Centre for Biology, Cibinong \\
\hline 70. & Siran, Sulistyo A. & FORDA, Climate Change and Policy Research Development Centre, Bogor \\
\hline 71. & Solichin & MRPP-GIZ, Palembang \\
\hline 72. & Stanley, Scott A. & Forest Carbon Consultants, Jakarta \\
\hline
\end{tabular}


Appendix 2. Continued

\begin{tabular}{cll}
\hline No. & Name & Institution \\
\hline 73. & Subiandono, Endro & $\begin{array}{l}\text { FORDA, Center for Forest Conservation and Rehabilitation Research and } \\
\text { Development, Bogor }\end{array}$ \\
74. Sugardiman, Ruandha A. & Ministry of Forestry, Jakarta \\
75. Sukandar & FORDA, Climate Change and Policy Research Development Centre, Bogor \\
76. Sukardjo, Sukristijono & LIPI, Research Center for Oceanography, Jakarta \\
77. Suratno, Agus & Zoological Society of London - Indonesia Programme, Bogor \\
78. Swickard, Naomi & Verified Carbon Standard Association, Thailand \\
79. Syaufina, Lailan & Bogor Agricultural University, Faculty of Forestry \\
80. & Toruan, Frans & DNPI, Jakarta \\
81. & van der Meer, Peter & Wageningen University and Research Centre, Alterra, The Netherlands \\
82. & Verchot, Louis & CIFOR, Bogor \\
83. Warren, Matthew & United States Forest Service, Northern Research Station, USA \\
84. Wibisono, Iwan Tri Cahyo & Wetlands International, Bogor \\
85. Widiastuti, Fransiska & SEKALA, Bali \\
86. Widyati, Enny & FORDA, Bogor \\
87. Yeager, Carey & USAID, Jakarta \\
\hline
\end{tabular}



CIFOR Working Papers contain preliminary or advance research results, significant to tropical forest issues, that need to be published in a timely manner. They are produced to inform and promote discussion. Their content has been internally reviewed but not undergone the lengthier process of external peer review.

The extent of tropical wetlands, the magnitude of loss, and the related socioeconomic ramifications of the destruction of Indonesian wetlands are of global significance. The carbon density and rates of land-cover change in these ecosystems are amongst the highest of any forest type on Earth. Therefore, addressing interrelated issues of climate change and land use could be valuable in generating new options on how mangroves and peatlands should be best managed. This paper is produced by bringing together Indonesian and international scientists from diverse backgrounds and with diverse experiences in both freshwater and coastal tropical wetlands. It describes the state of the science, significant research needs, and potential transdisciplinary approaches necessary to implement climate change adaptation and mitigation strategies.

This research was carried out as part of the CGIAR Research Programme, 'Forests, Trees and Agroforestry: Livelihoods, Landscapes and Governance'. The Programme aims to enhance management and use of forests, agroforestry and tree genetic resources across the landscape from forests to farms. The Center for International Forestry Research leads the collaborative programme in partnership with Bioversity International, the International Center for Tropical Agriculture and the World Agroforestry Centre.
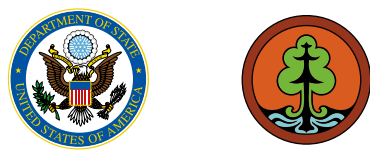

Center for International Forestry Research

CIFOR advances human wellbeing, environmental conservation and equity by conducting research to inform policies and practices that affect forests in developing countries. CIFOR is a CGIAR Consortium Research Center. CIFOR's headquarters are in Bogor, Indonesia and it also has offices in Asia, Africa and South America. 